\title{
EFFECTS OF RIVER DISCHARGE AND HIGH-TIDE STAGE ON SALINITY INTRUSION IN THE WEEKI WACHEE, CRYSTAL, AND WITHLACOOCHEE RIVER ESTUARIES, SOUTHWEST FLORIDA
}

By Dann K. Yobbi and Lari A. Knochenmus

U.S. GEOLOGICAL SURVEY

Water-Resources Investigations Report 88-4116

Prepared in cooperation with the

SOUTHWEST FLORIDA WATER MANAGEMENT DISTRICT

Tallahassee, Florida 


\section{DEPARTMENT OF THE INTERIOR}

MANUEL LUJAN, JR., Secretary

U.S. GEOLOGICAL SURVEY

Dallas L. Peck, Director

For additional information write to:

\section{District Chief}

U.S. Geological Survey

Suite 3015

227 North Bronough Street

Tallahassee, Florida 32301
Copies of this report may be purchased from:

U.S. Geological Survey Books and Open-File Reports

Federal Center, Building 810

Box 25425

Denver, Colorado 80225 


\section{CONTENTS}

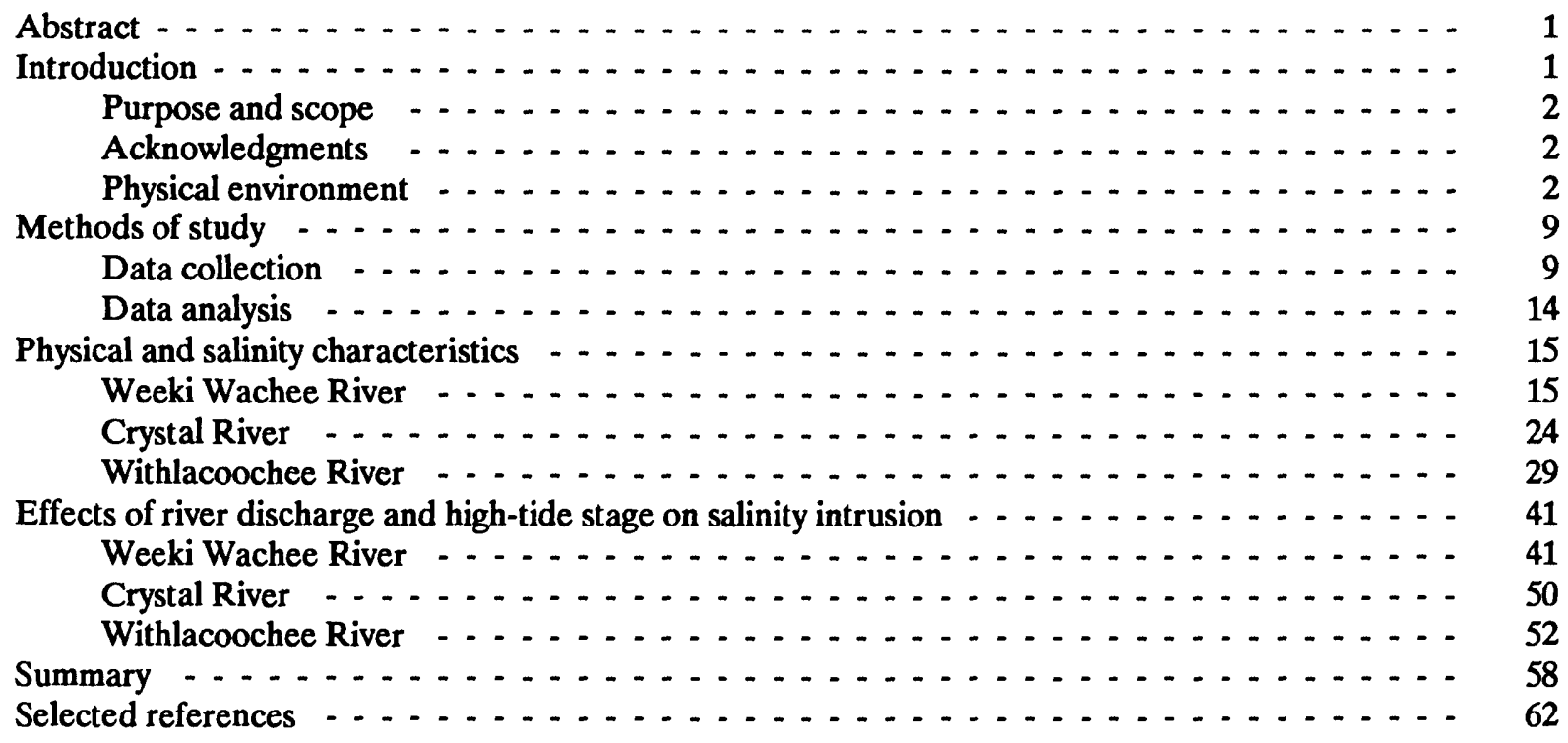

\section{ILLUSTRATIONS}

Figure 1. Map showing ground-water basin of the coastal springs-Withlacoochec River area including potentiometric surface of the Upper Floridan aquifer, May $1985 \ldots . . . \quad 3$

2. Graphs showing observed variations of tide stage and salinity at the mouth of the Withlacoochee River (site 54), February 19-21, $1985 \ldots \ldots . . . . . . . . . . .55$

3. Graph showing higher high-tide stage-duration curves for Weeki Wachee, Crystal, and Withlacoochee Rivers, October 1984 through September $1985 \ldots \ldots . . . . .$.

4. Map showing locations of coastal springs and rivers ..............

5-7. Maps showing locations of data-collection sites on:

5. Weeki Wachee River, Mud River, and Gulf of Mexico _... . . . . . . . 10

6. Crystal River and Gulf of Mexico . . . . . . . . . . . . . . . . . 11

7. Withlacoochee River and Gulf of Mexico ................. 12

8-31. Graphs showing:

8. Relation between discharge of Weeki Wachee River and water levels in Weeki Wachee well 283201082315601 . . . . . . . . . . . . . . . . . . . .

9. Average, minimum, and maximum mean monthly discharges, 1966 through 1984 , and monthly mean discharge, October 1984 through September 1985, for

Weeki Wachee River ... . . . . . . . . . . . . . . . . .

10. Duration curves for computed daily mean discharge of Weeki Wachec River for 1975 through 1984 and October 1984 through September 1985 . . . . . . . . .

11. Salinity distributions in a longitudinal section of the Weeki Wachee River for various daily mean river discharges and high-tide stages at river mile $0.05 \ldots . . . .$. 


\section{ILLUSTRATIONS - Continued}

Figure 8-31. Graphs showing-Continued

12. Relation between ratio of top-to-bottom salinity to distance downstream

from salt front at high-tide stages in the Weeki Wachee River . . . . . . .

13. Longitudinal distributions of vertically averaged salinity at high-tide stage in the Weeki Wachee River Estuary _. . . . . . . . . . . . . . . 22

14. Salinity duration curves for monitors at river miles 0.05 and 1.37 on the Weeki Wachee River, October 1984 through September 1985 _. . . . . . . 23

15. Average, minimum, and maximum mean monthly discharges of the Crystal River (site 36), 1965 through 1977 . . . . . . . . . . . . . . 25

16. Duration curve of daily mean discharges of Crystal River (site 36) for 1965 through 1977 . . . . . . . . . . . . . . . . . . . . 26

17. Salinity distributions in a longitudinal section of the Crystal River for various daily mean river discharges and high-tide stages at river mile $3.92 \quad \ldots . . .-28$

18. Relation between ratio of top-to-bottom salinity at site 29 (river mile 0.90 ) and high-tide stage at Crystal River (site 36) _. . . . . . . . . . . . . 29

19. Longitudinal distributions of vertically averaged salinity at high-tide stage in the Crystal River Estuary . . . . . . . . . . . . . . . . . . 30

20. Comparison between maximum upstream extent of the vertically averaged 25- and 18-parts-per-thousand salinities in the Crystal River Estuary and daily mean discharge and high-tide stage of Crystal River, October 1984 through September 1985 . . . . . . . . . - . . . . . -

21. Salinity duration curves for monitors at river miles 3.92 and 5.92 on Crystal River, October 1984 through September 1985 - . . . . . . . . -

22. Average, minimum, and maximum mean monthly discharges, 1970 through 1984, and monthly mean discharges, October 1984 through September 1985, of the Withlacoochee River at the bypass channel _. . . . . . . . . . . -

23. Duration curves of daily mean discharge for the Withlacoochee River at the bypass channel for 1970 through 1983 and October 1984 through September 1985 - - -

24. Salinity distributions in a longitudinal section of the Withlacoochee River for various daily mean discharges and high-tide stages at the river mouth - - - -

25. Longitudinal variations of top-to-bottom salinity ratios for various discharges and high-tide stages in the Withlacoochee River _. . . . . . . . . . . .

26. Longitudinal variations of surface and bottom salinities at high-tide stages in the Withlacoochee River Estuary for discharges of 993 to 1,610 cubic feet per second . . . . . . . . . . . . . . . . . . .

27. Longitudinal variations of surface and bottom salinities at high-tide stages in the Withlacoochee River Estuary for discharges of 511 to 958 cubic feet per second . . . . . . . . . . . . . . . . . . .

28. Variation in monthly salinity in Gulf of Mexico at site 49 and monthly mean discharge of Withlacoochee River at the bypass channel and Withlacoochee River at Inglis Dam, April 1983 through September 1985 - - - - - - - - - - -

29. Salinity duration curves for monitors at river miles $0.00,1.70$, and 2.96 on the Withlacoochee River, October 1984 through September 1985 - . . . . . -

30. Relation between salinity at river mile 0.05 and location of the maximum upstream extent of the vertically averaged 18- and 25-parts-pcr-thousand salinities in the Weeki Wachee River Estuary - . . . . . . . . . . .

31. Duration curves for computed location of the daily maximum upstream extent of the vertically averaged $0.5-, 5-, 18-$, and 25 -parts-per-thousand salinities in the Weeki Wachee River Estuary, October 1984 through September 1985 - - - 


\section{ILLUSTRATIONS - Continued}

Page

Figure 32. Maps showing duration of the daily maximum upstream extent of the vertically averaged 5- and 0.5-part-per-thousand salinities in the Weeki Wachee River, October 1984 through September $1985 \ldots \ldots \ldots \ldots$

33. Graphs showing duration curves of the daily maximum upstream extent of the vertically averaged 5 - and 0.5 -part-per-thousand salinities in the Weeki Wachee River for variable higher high tides and discharge . . . . . . .

34. Graphs showing relations between high-tide stage of Crystal River at river mile 3.92 and the maximum upstream extent of the vertically averaged 5- and 2-parts-per-thousand salinities _......................

35. Map showing duration of the daily maximum upstream extent of the vertically averaged 5- and 2-parts-per-thousand salinities in Crystal River for mean higher high-tide stage and variable discharge, October 1984 through September 1985 - - -

36-38. Graphs showing:

36. Duration curves of the daily maximum upstream extent of the vertically averaged 5- and 2-parts-per-thousand salinities in Crystal River for variable higher high tides and discharge, October 1984 through September 1985 - . - .

37. Relation between salinity at river mile 0.00 and location of the maximum upstream extent of the vertically averaged 18- and 25-parts-per-thousand salinities in the Withlacoochee River Estuary _. . . . . . . . . .

38. Duration curves for computed location of the daily maximum upstream extent of the vertically averaged $0.5-, 5-, 18-$, and 25 -parts-per-thousand salinities in the Withlacoochee River Estuary, October 1984 through September 1985 - -

39. Maps showing duration of the daily maximum upstream extent of the vertically averaged 5- and 0.5-part-per-thousand salinities in the Withlacoochee River, October 1984 through September 1985 . . . . . . . . . . . . . . .

40. Graphs showing duration curves of the daily maximum upstream extent of the vertically averaged 5- and 0.5-part-per-thousand salinities in the Withlacoochee River for higher high tides and discharge, October 1984 through September 1985

$-\cdots$

\section{TABLES}

Table 1. Summary of mean monthly and monthly mean observed tide-stage data for the Weeki Wachee, Crystal, and Withlacoochee Rivers _ . . . . . . . . . . 6

2. Hydrologic data for coastal springs _ . . . . . . . . . . . . . . . 9

3. Conversions from specific conductance to salinity _ . . . . . . . . . . . 13

4. Description of observation sites _. . . . . . . . . . . . . . . 15

5. Chemical analysis of water from Weeki Wachee Springs and Salt Spring _ . . - . - 19

6. Low-flow frequencies of Crystal River at Crystal River, October 1964 to September 1977 . . . . . . . . . . . . . . . . . . . 24

7. Chemical analysis of water from Tarpon Spring in Kings Bay near Crystal River, January 8, 1975 . . . . . . . . . . . . . . . . . . . . . . 27

8. Low-flow frequencies of Withlacoochee River bypass channel near Inglis, October 1970 to September 1981 . . . . . . . . . . . . . . . . . . 36

9. Chemical analysis of water from Lake Rousseau $\quad \ldots \ldots \ldots$. . . . . . . . . . 36

10. Simulated reduction of spring flow due to withdrawing $\mathbf{4 0}$ million gallons per day

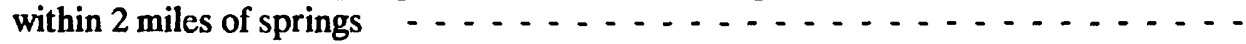

11. Effect of varying discharge and high-tide stage on the daily maximum upstream extent of the vertically averaged 5- and 0.5-part-per-thousand salinities in the Withlacoochee River ........................... 


\title{
EFFECTS OF RIVER DISCHARGE AND HIGH-TIDE STAGE ON SALINITY INTRUSION IN THE WEEKI WACHEE, CRYSTAL, AND WITHLACOOCHEE RIVER ESTUARIES, SOUTHWEST FLORIDA
}

\author{
By Dann K. Yobbi and Lari A. Knochenmus
}

\begin{abstract}
The Weeki Wachee, Crystal, and Withlacoochee Rivers are coastal streams flowing into the Gulf of Mexico that may be affected by either future surface-water or ground-water withdrawals. Reduction of river discharge may affect the upstream extent of saltwater intrusion in the three rivers; however, under certain reduced low-flow discharges, the estimated change in upstream extent of saltwater intrusion is on the order of several tenths of a mile and frequently is within the range of predicted error.

Data on river discharge, high-tide stage, and salinity are used to characterize salinity distributions in the Weeki Wachee, Crystal, and Withlacoochee River Estuaries. Salinity of the rivers increases downstream. The difference between surface and bottom salinities varies from river to river. Vertical differences in salinity are smallest in the Weeki Wachee River and largest in the Withlacoochee River Estuary.

Multiple linear-regression analysis was used to relate the maximum upstream extent of the vertically averaged 5- and 0.5-part-per-thousand salinities in the Weeki Wachee and Withlachoochee Rivers and the vertically averaged 5- and 2-parts-per-thousand salinities in Crystal River to daily discharge of each river and high-tide stage of the Gulf of Mexico. For the Weeki Wachee River, two linear equations were developed for different ranges of discharge for each salinity position. Streamflow was the most significant variable in each equation. For the Crystal River, one linear equation was developed for each salinity location. High-tide stage was the most significant variable in each equation. For the Withlacoochee River, linear equations were developed for the surface, bottom, and vertically averaged salinity locations. Discharge was the most significant variable in locating the bottom salinity position, and high-tide stage was the most significant variable for locating the surface salinity position. The mean location of both salinities responded slightly more to tide stage than to discharge.
\end{abstract}

Pumping 40 million gallons per day (61.9 cubic feet per second) from a well field near the springs would result in a 43-cubic-foot-per-second reduction of discharge in the Weeki Wachee River. This reduction is estimated to cause an upstream movement of the vertically averaged 5- and 0.5-part-per-thousand salinities of about 0.3 and 0.2 mile, respectively, at the 25-percent flowduration interval (199 cubic feet per second). The frequency of a salinity intrusion greater than 0.5 part per thousand at mile 1.5 is estimated to increase from 6 to 65 percent. The well-field pumpage would result in a 61-cubic-foot-persecond reduction in discharge in the Crystal River. The reduction in flow would cause an insignificant upstream movement of the vertically averaged 5- and 2-parts-per-thousand salinities at the 90-day, 20-year low flow.

Withdrawal of 208 cubic feet per second (50 percent of the 90-day, 2-year low flow) from the Withlacoochee River is estimated to cause an upstream movement of both the vertically averaged 5- and 0.5-part-per-thousand salinities of about 0.2 mile. It would also increase the frequency of daily salinity intrusion (0.5-part-per-thousand salinity) at mile 3.0 from 33 to 85 percent. For the 7-day, 2-year low flow (670 cubic feet per second), 50-percent reduction of flow would cause an upstream movement of the vertically averaged 5- and 0.5-part-per-thousand salinities of about 0.4 and 0.3 mile, respectively.

\section{INTRODUCTION}

Coastal southwest Florida is undergoing rapid urban development that has increased the demand for freshwater. As demand for freshwater increases in coastal areas, coastal streams and new regional well fields may be used to augment present supplies. There is concern that salinity in the rivers would increase as a result of withdrawals from either source.

The Weeki Wachee, Crystal, and Withlacoochee Rivers are coastal streams in Citrus and Hernando Counties that discharge about 2,300 
$\mathrm{ft}^{3} / \mathrm{s}$ of water to the Gulf of Mexico (fig. 1). Fisheries and related estuarine resources in the area are substantial and are the foundation for important sport and commercial fishing industries. The rivers are potential sources of water supply. The export of either surface or ground water from future regional well fields to urban centers outside the drainage basin would reduce flow in the rivers and could increase estuarine salinity.

Biological productivity of the estuarine zone is directly linked to salinity. Salinity is known to be substantially influenced by the quantity and variability of streamflow as well as tide stages. Sufficient data were not available to evaluate relations between discharge, tide stage, and salinity in the Weeki Wachee, Crystal, or Withlacoochee River Estuaries. Knowledge of such relations is needed to help water-resources managers and planners to manage and conserve freshwater resources and determine streamflow requirements to help maintain viable and productive estuaries.

Salinity refers to the salt content of water, or more precisely, the concentration of dissolved solids in water. Forch and others (1902) defined salinity as "the total amount of solid material in grams contained in one kilogram of seawater when all the carbonate has been converted to oxide, the bromide and iodine replaced by chlorine, and all organic matter completely oxidized." Salinity is generally expressed as a concentration, in parts per thousand (ppt).

In this report, a salinity of $0.5 \mathrm{ppt}$ is used to define the upstream extent of saltwater intrusion in the Weeki Wachee and Withlacoochee Rivers, and a salinity of 2 ppt is used for the Crystal River. These concentrations were selected because they are only slightly higher than the background salinity of the inflowing water of each river and each clearly indicates the presence of some saltwater from the gulf.

This investigation was made by the U.S. Geological Survey in cooperation with the Southwest Florida Water Management District.

\section{Purpose and Scope}

The purpose of this report is to provide the analysis and supporting data required in evaluating the effects of river discharge and tide stage on salinity intrusion at high tide in the Weeki Wachee, Crystal, and Withlacoochee River
Estuaries. Data on salinity, river discharge, and high tides are used to describe the physical and salinity characteristics of the estuaries. Relations between river discharge, high-tide stage, and the maximum upstream extent of the vertically averaged 5- and 0.5-ppt salinities at high tide in the Weeki Wachee and Withlacoochee River Estuaries, and the vertically averaged 5- and 2ppt salinities in Crystal River Estuary are evaluated by regression techniques. These relations are used to illustrate the effects of discharge on the daily maximum upstream extent of salinity locations in the three rivers. Examples that show the effects of reduced spring flow caused by wellfield pumpage on salinity locations in Weeki Wachee and Crystal Rivers are presented.

\section{Acknowledgments}

M.S. Flannery of the Southwest Florida Water Management District contributed useful data and suggestions during the course of the study. The cooperation of landowners in permitting construction of hydrologic instrument shelters is gratefully acknowledged.

\section{Physical Environment}

The study area lies within the Gulf Coastal Lowlands as described by Vernon (1951). Marine terraces and sand dunes are the dominant topographic features. Along the coast, saltmarshes with palm covered islands dominate. The coast is low, and land altitudes range from sea level at the gulf coast to about 30 feet above sea level along the eastern edge of the study area. The coastline is broad and flat, dotted with many small islands separated by shallow bays.

The most distinctive topographic feature is the well-defined Pamlico Terrace (White, 1970, p. 143), an ancient shoreline 25 to 30 feet above present sea level, 2 to 15 miles inland of the coast, and generally running parallel to the present shoreline. It extends beneath present sea level to a submerged shoreline. East of the Pamlico Terrace are sand hills pocketed by sinkholes and springs. The saltmarshes and swamps along the coast grade into a hardwood hammock belt with sandy pine and oak forests inland of the terrace scarp.

The near offshore areas of the Gulf of Mexico are shallow (less than 20 feet average depth) and exhibit little relief. The bottom is covered by a thin, discontinuous sediment veneer and is 


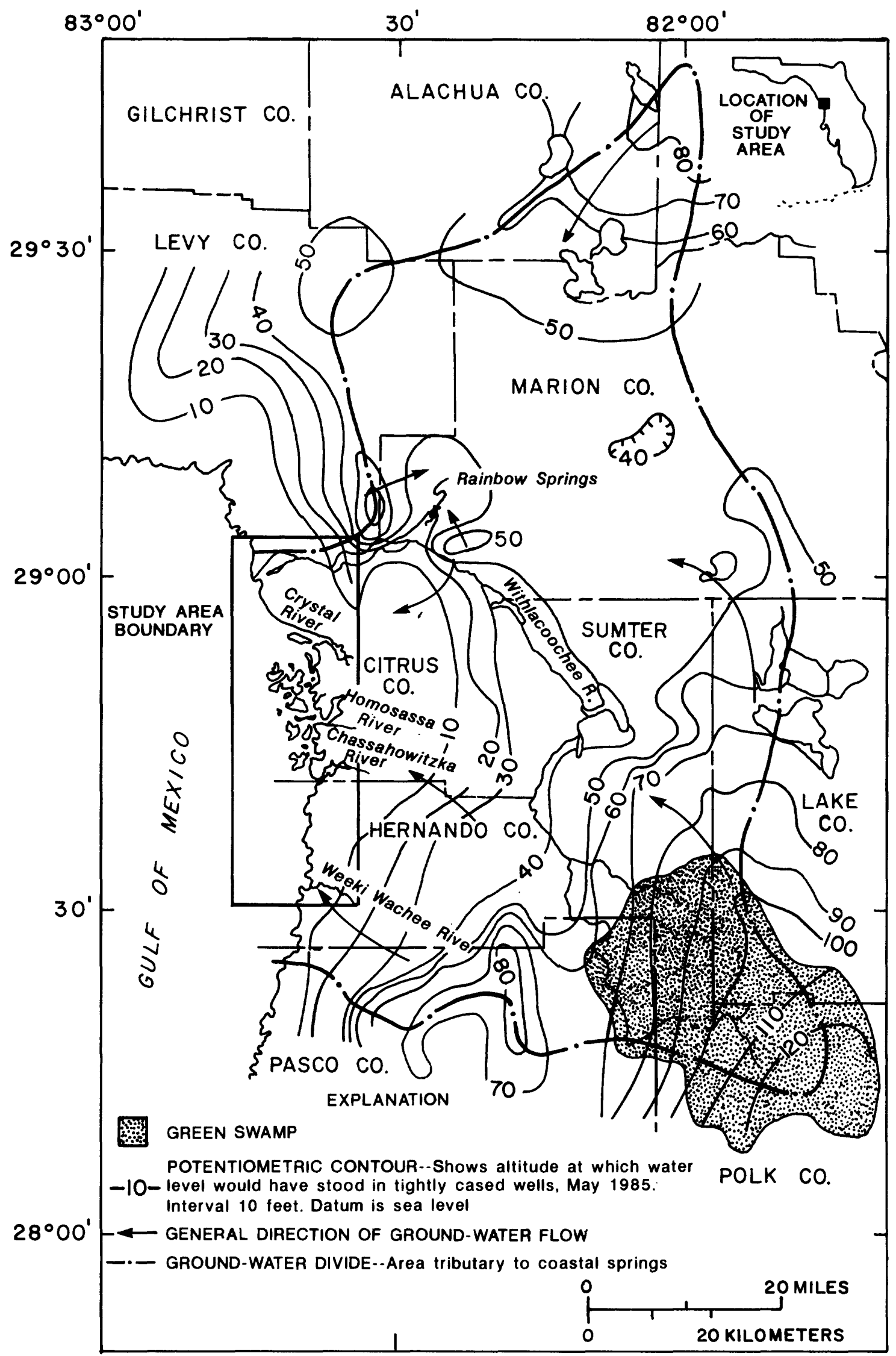

Figure 1.-Ground-water basin of the coastal springs-Withlacoochee River area including potentiometric surface of the Upper Floridan aquifer, May 1985. (Modified from Barr, 1985.) 
characterized by a karst platform with limestone outcrops, sinks, and a few submarine springs. Many of the sinks and springs have been filled by sand transported by a long shore current flowing northward in the Gulf of Mexico (Wetterhall, 1964). The nature and number of karst features appear to decrease away from shore (Brooks, 1973).

Tides in the study area are of the mixed semidiurnal type. A higher high and lower high tide, as well as a higher low and lower low tide, are possible each day (fig. 2). The diurnal tidal ranges are about 4.1 feet at the mouth of the Withlacoochee River, about 3.2 feet at the mouth of the Weeki Wachee River, and about 2.6 feet near the mouth of the Crystal River. Tide heights are greatly influenced by wind direction and velocity, being raised by strong winds from the west and reduced by easterly winds. Winds have a prevailing northerly direction during late fall and winter and a southerly direction during the remainder of the year (Jordan, 1973). A summary of tide-stage data is given in table 1 .

Duration curves of the observed higher high-tide stage for October 1984 through September 1985 at the mouths of the Weeki Wachee and Withlacoochee Rivers and at Crystal River about 0.1 mile upstream of Salt River are shown in figure 3. The extreme tides in the less than 5-percent range reflect the influence of Hurricane Elena that passed offshore August 31 and September 1, 1985.

There is little surface drainage in the area. Most water in the rivers is derived from ground water. Near the coast, springs and seeps discharge more than a billion gallons of water per day from the aquifer to rivers, swamps, and estuarine marshes that eventually flow to the Gulf of Mexico. No streams within the study area, with the exception of the Withlacoochee River, extend more than a few miles inland.

Most spring water exits from solution cavities in the limestone and dolomite strata of the Upper Floridan aquifer, which is at or near land surface in the study area. Saltwater is present in the upper part of the aquifer near the coast and at a depth of about 100 feet at a distance of 1 to 5 miles inland (Mills and Ryder, 1977). Spring flow in most of the coastal area is affected by tidal fluctuations in the Gulf of Mexico, and springs may either discharge fresh or brackish water.
The ground-water basin of the coastal springs-Withlacoochee River area comprises about $3,400 \mathrm{mi}^{2}$, based on the potentiometric-surface map of the Upper Floridan aquifer for May 1985 (fig. 1) prepared by Barr (1985). Rainfall averages $55 \mathrm{in} / \mathrm{yr}$ (Mann and Cherry, 1969) in the basin and is the source of water for the system. Water moves from areas of high potential to areas of low potential normal to the contour lines; generally, movement is from the interior toward the coastline and vertically upward to discharge as springs or diffuse upward leakage into low-lying coastal swamps. The pronounced inland curvature of the potentiometric contours in west Citrus County (fig. 1) is indicative of the ground water discharging from the Upper Floridan aquifer to springs in the Crystal, Homosassa, and Chassahowitzka Rivers. Spring flow generally increases during wet periods, but because of storage in the system, the increase in spring flow seemingly is not always proportional to the increase in rainfall (Wetterhall, 1964).

The principal surface drainage for the coastal area is, from north to south, the Withlacoochee, Crystal, Homosassa, Chassahowitzka, and Weeki Wachee Rivers (fig. 4). With the exception of the Withlacoochee River, each of these four streams originates from a spring, or group of springs, of first-order magnitude (average flow of at least $100 \mathrm{ft}^{3} / \mathrm{s}$, or $64.6 \mathrm{Mgal} / \mathrm{d}$ ). Numerous other smaller springs and spring-fed streams dot the coastal fringes of the study area. These streams are generally shallow, and they alternately flood and drain marshes during tidal fluctuations. Names and discharge rates for 28 springs and spring groups that discharge to streams are given in table 2.

The Withlacoochee River (fig. 4) is the only major river with surface drainage outside the study area. The Withlacoochee River drainage area includes about $2,020 \mathrm{mi}^{2}$, and the river extends from the Green Swamp in northern Polk County along the Citrus-Levy County line to the Gulf of Mexico. Along much of its course, the river is in hydrologic contact with the Upper Floridan aquifer and at times is augmented by spring flow and at times recharges the aquifer (Sinclair, 1978, p. 9). In the lower reaches of the river, about 50 percent of base flow is from the Upper Floridan aquifer with about $700 \mathrm{ft}^{3} / \mathrm{s}$ contributed by Rainbow Springs (fig. 1). 

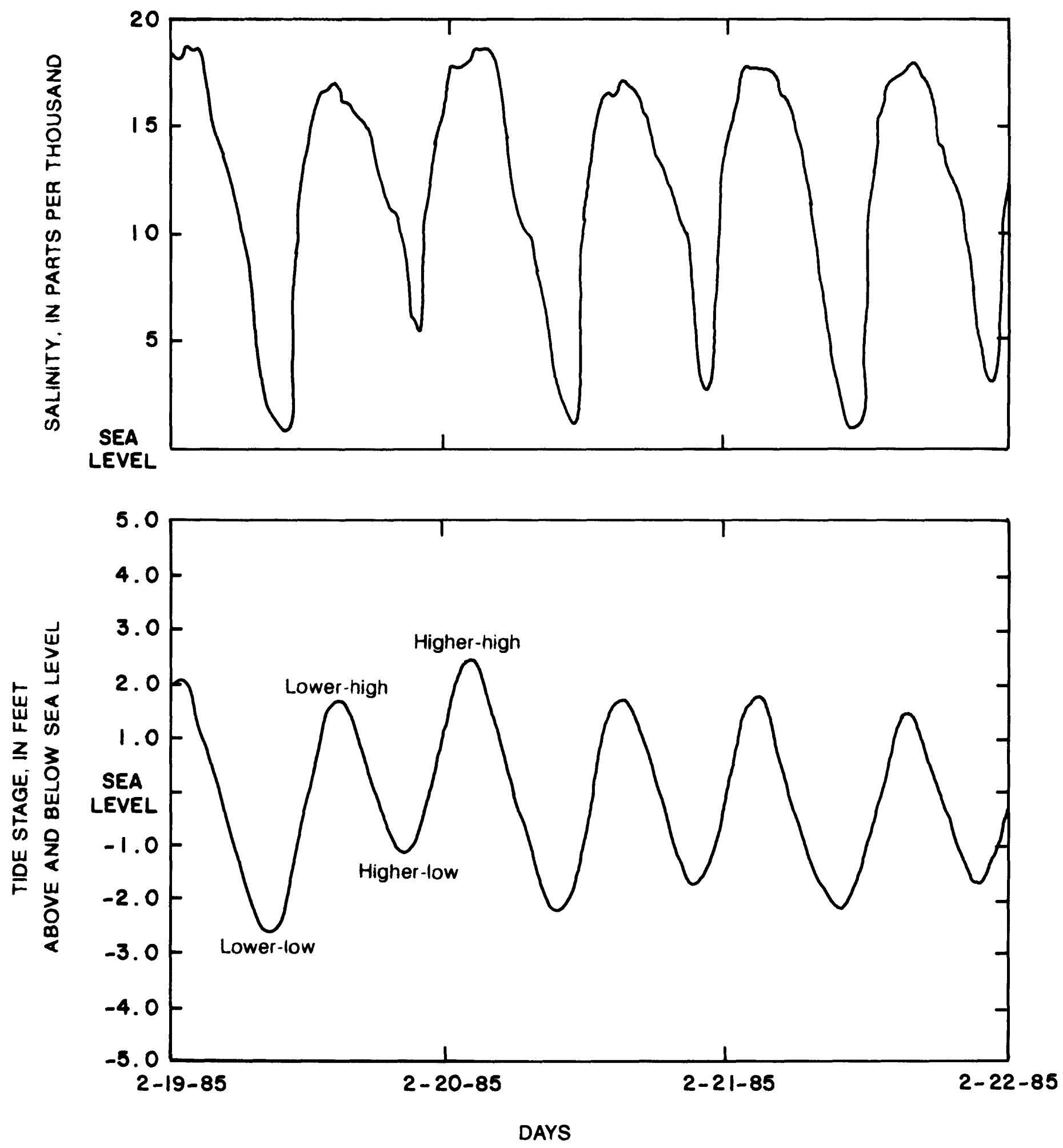

Figure 2.-Observed variations of tide stage and salinity at the mouth of the Withlacoochee River (site 54), February 19-21, 1985. 
Table 1. - Summary of mean monthly and monthly mean observed tide-stage data for the Weeki Wachee, Crystal, and Withlacoochee Rivers

[Stage data are in feet above or below (-) sea level]

\begin{tabular}{|c|c|c|c|c|c|c|c|c|c|c|c|c|c|}
\hline \multirow{2}{*}{ Tide } & \multirow[b]{2}{*}{ Year $^{1}$} & \multicolumn{11}{|c|}{ Month } & \multirow[b]{2}{*}{ Dec } \\
\hline & & Jan. & Feb. & Mar. & Apr. & May & June & July & Aug. & Sept. & Oct. & Nov. & \\
\hline \multicolumn{14}{|c|}{ Weeki Wachee River, river mile 0.05} \\
\hline \multirow[t]{2}{*}{ Higher high } & $1975-84$ & 1.81 & 1.85 & 2.06 & 2.11 & 2.28 & 2.33 & 2.39 & 2.35 & 2.41 & 2.10 & 2.10 & 1.93 \\
\hline & $1984-85$ & 2.11 & 1.85 & 1.92 & 2.02 & 2.36 & 2.34 & 2.55 & 2.72 & 2.37 & 2.43 & 1.93 & 2.21 \\
\hline \multirow[t]{2}{*}{ Lower low } & $1975-84$ & -1.40 & -1.33 & -1.21 & -1.15 & -1.07 & -.92 & -.83 & -.81 & -.72 & -.97 & -1.05 & -1.25 \\
\hline & $1984-85$ & -1.14 & -1.42 & -1.25 & -1.20 & -1.00 & -.92 & -.91 & -.67 & -.78 & -.77 & -.94 & -1.13 \\
\hline \multicolumn{14}{|c|}{ Weeki Wachee River, river mile $\mathbf{2 . 2 0}$} \\
\hline \multirow{2}{*}{$\begin{array}{l}\text { Higher high } \\
\text { Lower low }\end{array}$} & $1984-85$ & 2.25 & 2.10 & 2.04 & 2.02 & 2.27 & 2.35 & 2.35 & 2.67 & 2.30 & 2.48 & 2.21 & 2.30 \\
\hline & $1984-85$ & 1.03 & .94 & .90 & .74 & .64 & .68 & .71 & 1.16 & .90 & 1.28 & 1.17 & 1.05 \\
\hline \multicolumn{14}{|c|}{ Crystal River, river mile 3.92} \\
\hline \multirow[t]{2}{*}{ Higher high } & $1975-84$ & 1.64 & 1.68 & 1.86 & 1.98 & 2.09 & 2.18 & 2.28 & 2.23 & 2.25 & 1.92 & 1.91 & 1.75 \\
\hline & $1984-85$ & 2.10 & 1.98 & 1.98 & 1.95 & 2.35 & 2.44 & 2.47 & 2.68 & 2.27 & 2.35 & 1.97 & 2.17 \\
\hline \multirow[t]{2}{*}{ Lower low } & $1975-84$ & -.95 & -.92 & -.72 & -.67 & -.54 & -.42 & -.28 & -.34 & $\cdot .23$ & -.51 & -.58 & -.82 \\
\hline & $1984-85$ & -.58 & -.78 & -.78 & - .66 & -.33 & -.22 & -.19 & -.01 & -.20 & -.11 & $\cdot .47$ & -.48 \\
\hline \multicolumn{14}{|c|}{ Withlacoochee River, river mile 0.00} \\
\hline \multirow{2}{*}{$\begin{array}{l}\text { Higher high } \\
\text { Lower low }\end{array}$} & $1984-85$ & 2.27 & 2.17 & 2.21 & 2.25 & 2.62 & 2.76 & 2.80 & 3.10 & 2.70 & 2.77 & 2.06 & 2.50 \\
\hline & $1984-85$ & -1.66 & -1.97 & -1.82 & -1.88 & -1.62 & -1.66 & -1.51 & -1.17 & -1.40 & -1.23 & -1.50 & -1.62 \\
\hline \multicolumn{14}{|c|}{ Withlacoochee River, river mile 6.60} \\
\hline \multirow[t]{2}{*}{ Higher high } & $1968-84$ & 2.35 & 2.38 & 2.61 & 2.73 & 2.85 & 2.94 & 3.07 & 3.09 & 3.07 & 2.78 & 2.68 & 2.48 \\
\hline & $1984-85$ & 2.46 & 2.40 & 2.35 & 2.46 & 2.85 & 3.01 & 3.05 & 3.37 & 2.95 & 2.97 & 2.49 & 2.72 \\
\hline \multirow[t]{2}{*}{ Lower low } & $1968-84$ & -1.28 & -1.15 & -.94 & -.87 & -.94 & -.87 & -.66 & -.55 & -.36 & -.60 & -.78 & -1.10 \\
\hline & $1984-85$ & -1.32 & -1.62 & -1.58 & -1.64 & -1.42 & -1.47 & -1.25 & -.56 & -.81 & -.79 & -1.03 & -1.24 \\
\hline
\end{tabular}

${ }^{1}$ October 1975-September 1984, October 1984-September 1985, and October 1968-September 1984.

Many springs along the coast discharge brackish water (table 2 ). In general, the salinity decreases with distance inland from the coast because water levels in the Upper Floridan aquifer are high and the saltwater exists in the aquifer only at depth. At times of high water levels in the aquifer, the depth of saltwater is greatest and discharge from the spring tends to be freshest. At times of low water levels, the depth to the saltwater is decreased. Under this condition, saltwater in the aquifer may mix with freshwater flowing toward the spring opening, causing increased salinity in the spring discharge.

The distribution of salinity in the tidally affected reaches of the study area varies longitudinally, vertically, and with time. The variations of salinity within a cross section at a given location are dependent primarily on the combined effects of flow and tidal conditions, both of which vary seasonally. On the average, streamflow, like tides, is slightly higher in summer and fall than in winter and spring, and salinities are greater during periods of lower freshwater flow and higher tides and lesser during periods of higher freshwater flow and low tides.

Salinity in the spring-fed streams and marshes is affected mostly by movement of saline water from the gulf during tidal fluctuations. Because the source of most saline water in a tidal stream is the gulf, changes in tide stage will affect the quantity of saline water in the river. Tide stage and salinity in the Withlacoochee River at its mouth as functions of time are shown in figure 2 . Maximum and minimum salinities in the streams occur just after maximum and minimum tide stages and at about the time of slack water (minimum velocity).

The nearshore gulf waters off the study area are generally low in salinity due to high rainfall and large volumes of freshwater that discharge from rivers and springs along the coast. Flow from these rivers and springs is responsible for most saltwater dilution within the coastal area and in the near-shore area. Current direction in the gulf and wind direction also play important roles in distributing freshwater along the coast and out to sea. 


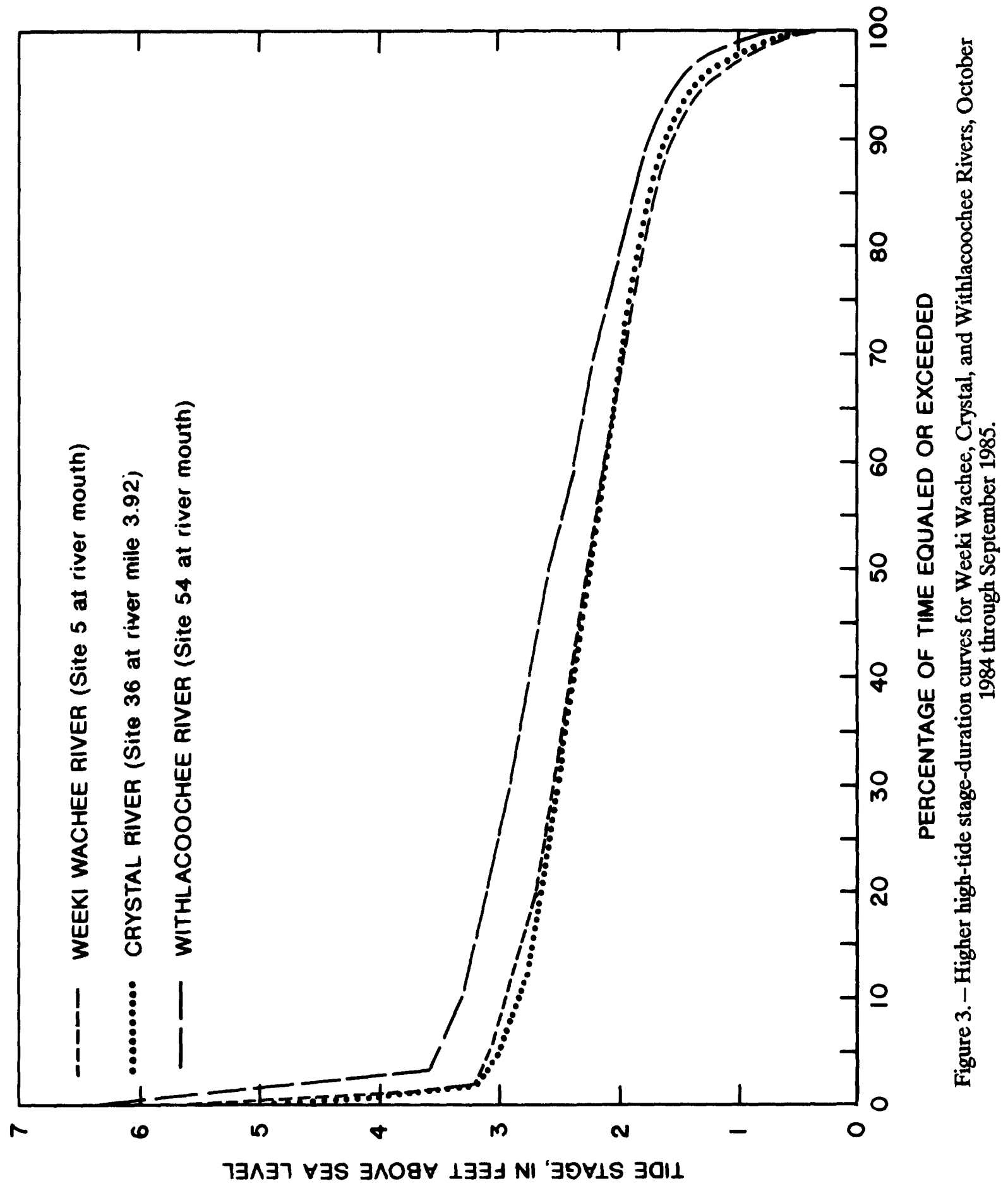




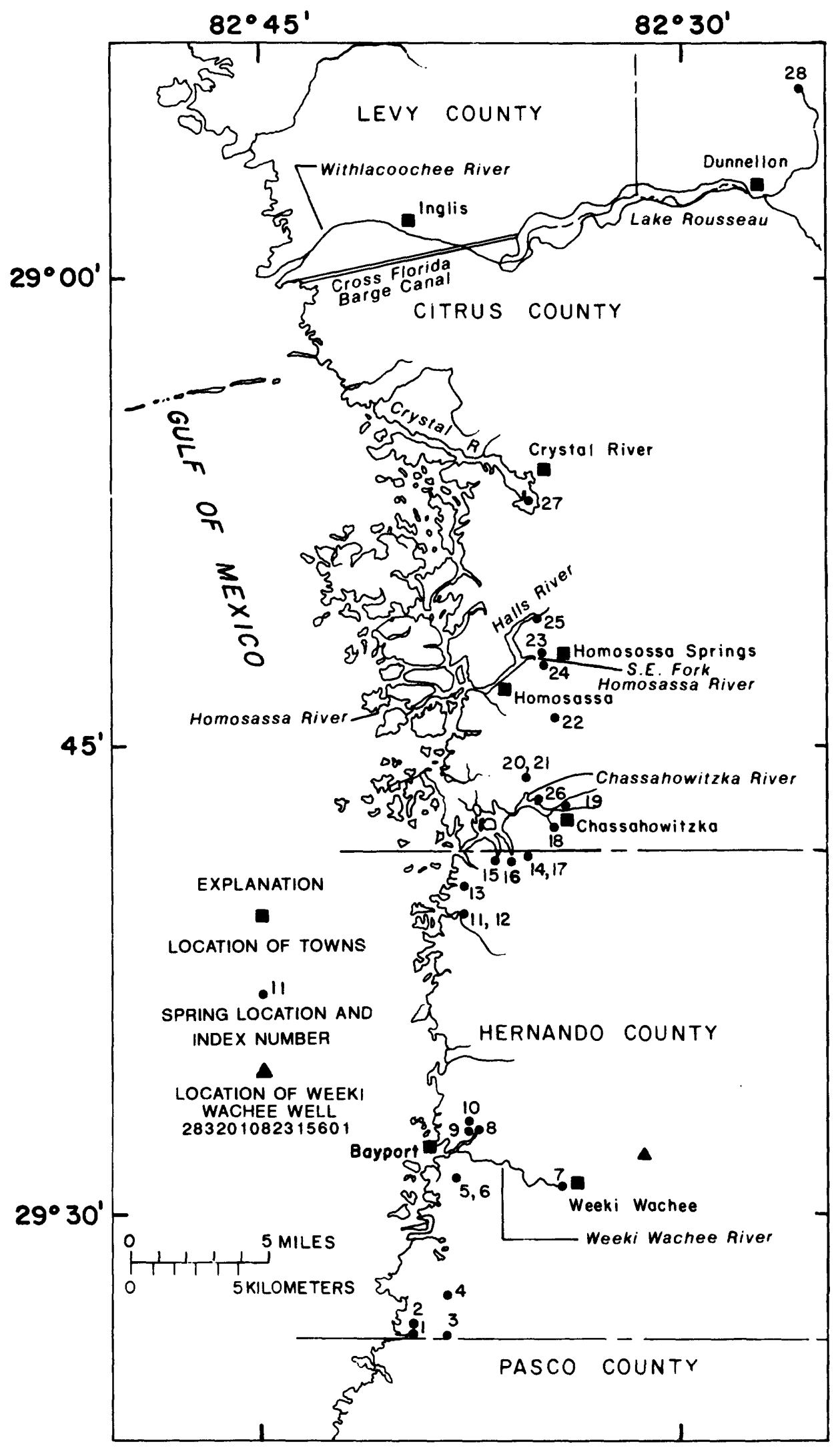

Figure 4. - Locations of coastal springs and rivers. 
Table 2. - Hydrologic data for coastal springs

[ $\mathrm{ft}^{3} / \mathrm{s}$, cubic feet per second; mg/L, milligrams per liter; --, no data]

\begin{tabular}{|c|c|c|c|c|c|c|c|c|}
\hline \multirow[t]{2}{*}{$\begin{array}{l}\text { Spring } \\
\text { No. } \\
\text { (fig. 4) }\end{array}$} & \multirow[t]{2}{*}{ Spring name } & \multirow[t]{2}{*}{$\begin{array}{l}\text { Period } \\
\text { of } \\
\text { record }\end{array}$} & \multirow[t]{2}{*}{$\begin{array}{c}\text { Number } \\
\text { of } \\
\text { discharge } \\
\text { measure- } \\
\text { ments }\end{array}$} & \multicolumn{4}{|c|}{$\begin{array}{c}\text { Instantaneous } \\
\text { discharge } \\
\left(\mathrm{ft}^{3} / \mathrm{s}\right)\end{array}$} & \multirow[t]{2}{*}{$\begin{array}{c}\text { Average } \\
\text { chloride } \\
\text { concentra- } \\
\text { tions }^{1} \\
(\mathrm{mg} / \mathrm{L})\end{array}$} \\
\hline & & & & Average & & $\overline{\text { Rang }}$ & & \\
\hline 1 & Unnamed spring No. 1 & $1964-65$ & 6 & 8.7 & 5 & - & 11.0 & 391 \\
\hline 2 & Boat Spring & $1962-64$ & 2 & 3.8 & 1.5 & - & 6.0 & 17 \\
\hline 3 & Bobhill Springs & $1961-72$ & 6 & 3.3 & 2.0 & - & 4.4 & 5 \\
\hline 4 & Unnamed spring No. 2 & 1960 & 1 & 1 & - & & -- & 5 \\
\hline 5 & Unnamed spring No. 4 & 1962 & 1 & 10.0 & -- & & -- & 1,600 \\
\hline 6 & Unnamed spring No. 5 & 1962 & 1 & 12.5 & -- & & -- & 1,500 \\
\hline 7 & Weeki Wachee Springs & $1917-74$ & 364 & 176 & 101 & - & 275 & 5 \\
\hline 8 & Salt Spring & $1961-75$ & 11 & 30.6 & 24.7 & - & 38.9 & 912 \\
\hline 9 & Mud Spring & $1961-75$ & 6 & 52.0 & 0 & - & 128 & 8,000 \\
\hline 10 & Unnamed spring No. 6 & 1960 & 1 & ${ }^{2} 5$ & $-\cdot$ & & - & 2,700 \\
\hline 11 & Unnamed spring No. 7 & 1961 & 1 & ${ }^{2} 50$ & - & & -- & -. \\
\hline 12 & Blind Spring & 1961 & 1 & 50.3 & -- & & -- & 4,600 \\
\hline 13 & Unnamed spring No. 8 & 1961 & 1 & $2_{10}$ & -- & & - & 6,400 \\
\hline 14 & Unnamed spring No. 9 & $1961-64$ & 3 & 28.8 & 20.9 & - & 35.4 & 136 \\
\hline 15 & Unnamed spring No. 10 & 1961 & 1 & 5 & -- & & -- & 4,300 \\
\hline 16 & Unnamed spring No. 11 & $1961-64$ & 2 & 15.6 & 5 & - & 26.2 & 3,800 \\
\hline 17 & Unnamed spring No. 12 & $1961-65$ & 6 & 28.6 & 9.1 & - & 39.9 & 2,110 \\
\hline 18 & Baird Creek Springs & $1964-65$ & 5 & 31.1 & 11.1 & - & 53.1 & 2,350 \\
\hline 19 & Chassahowitzka Springs & $1930-72$ & 81 & 139 & 31.8 & - & 197 & 127 \\
\hline 20 & Ruth Spring & $1961-72$ & 6 & 8.8 & 8.0 & - & 11.8 & 460 \\
\hline 21 & Potter Spring & $1961-65$ & 6 & 6.5 & 0 & - & 22.0 & 460 \\
\hline 22 & Hidden River Springs & $1964-65$ & 5 & 26.5 & 7.0 & - & 65.6 & 1,300 \\
\hline 23 & Homosassa Springs & $1931-74$ & 90 & 106 & 80 & - & 165 & 812 \\
\hline 24 & Southeast Fork Homosassa Springs & $1931-74$ & 89 & 69.1 & 33 & - & 129 & 54 \\
\hline 25 & Halls River Springs & $1964-66$ & 12 & 162 & 95.7 & - & 291 & 1,020 \\
\hline 26 & Salt Creek Springs & 1961 & 0 & -- & -- & & -- & 1,900 \\
\hline 27 & Crystal River Springs & $1964-75$ & (3) & 916 & ${ }^{4}-1,520$ & - & 4,320 & 820 \\
\hline 28 & Rainbow Springs & $1899-1974$ & (5) & 763 & 487 & - & 1,230 & 3 \\
\hline
\end{tabular}

${ }^{1}$ Average chloride concentration determined from individual measurements.

${ }^{2}$ Estimated.

${ }^{3}$ Daily discharge, tidally affected.

${ }^{4}$ Negative sign indicates upstream flow.

${ }^{5}$ Daily discharge.

The surface circulation in the Gulf of Mexico is dominated by a loop current that enters the gulf in the southwest, moves in a clockwise loop, and exits the gulf to the southeast. The current moves enough water to completely replace the water in the gulf in 30 months (Jones, 1973). It varies seasonally and influences shelf circulations that produce the northward counter clockwise current in the near-shore area off western Florida, including the study area.

\section{METHODS OF STUDY \\ Data Collection}

The field data-collection program consisted of continuous tide-stage, salinity (specific conductance), and streamflow monitoring and supplemental midchannel salinity measurements along the estuaries (figs. 5, 6, and 7). Data collection began in May 1982 and continued through September 1985. Continuous recording stations 


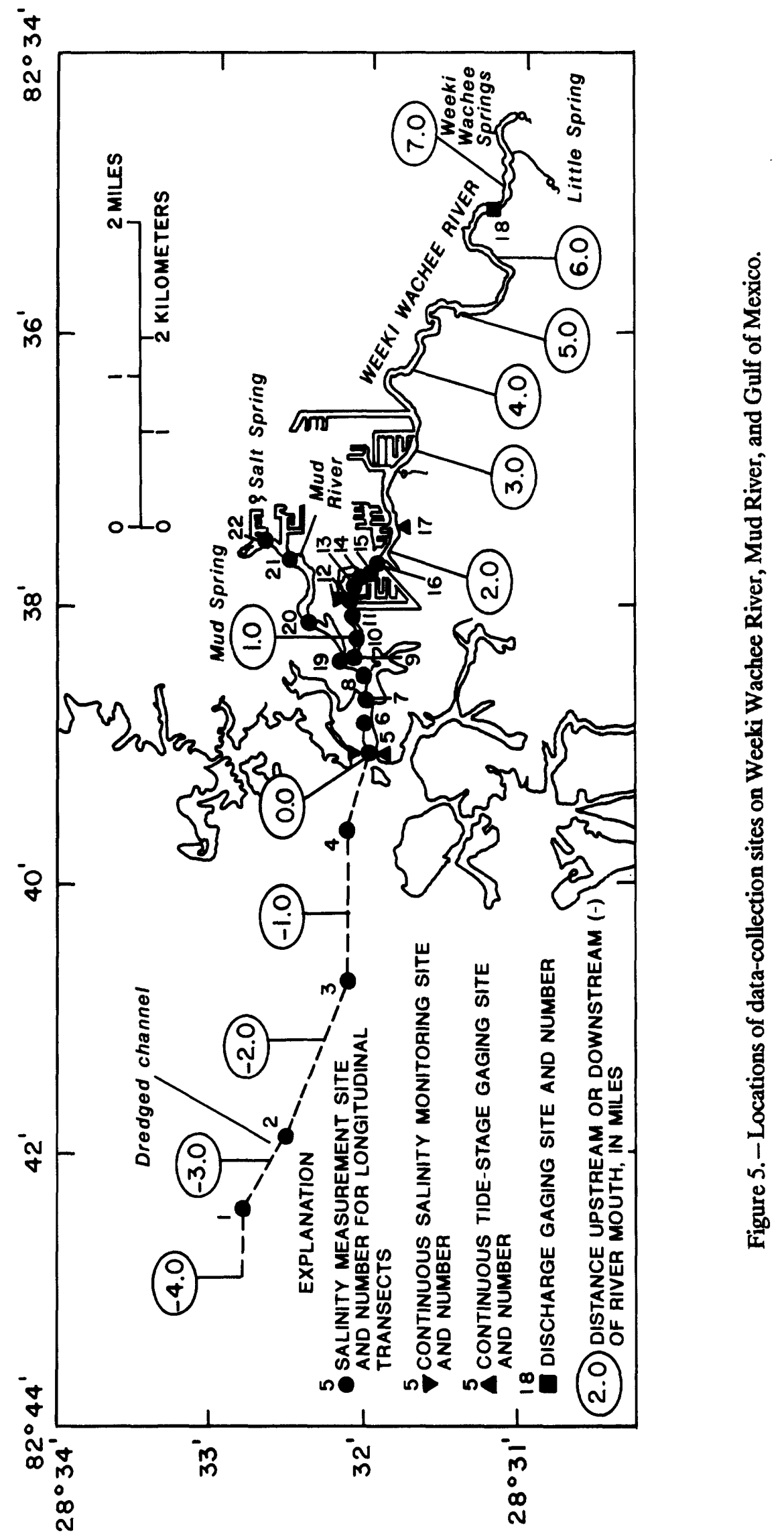




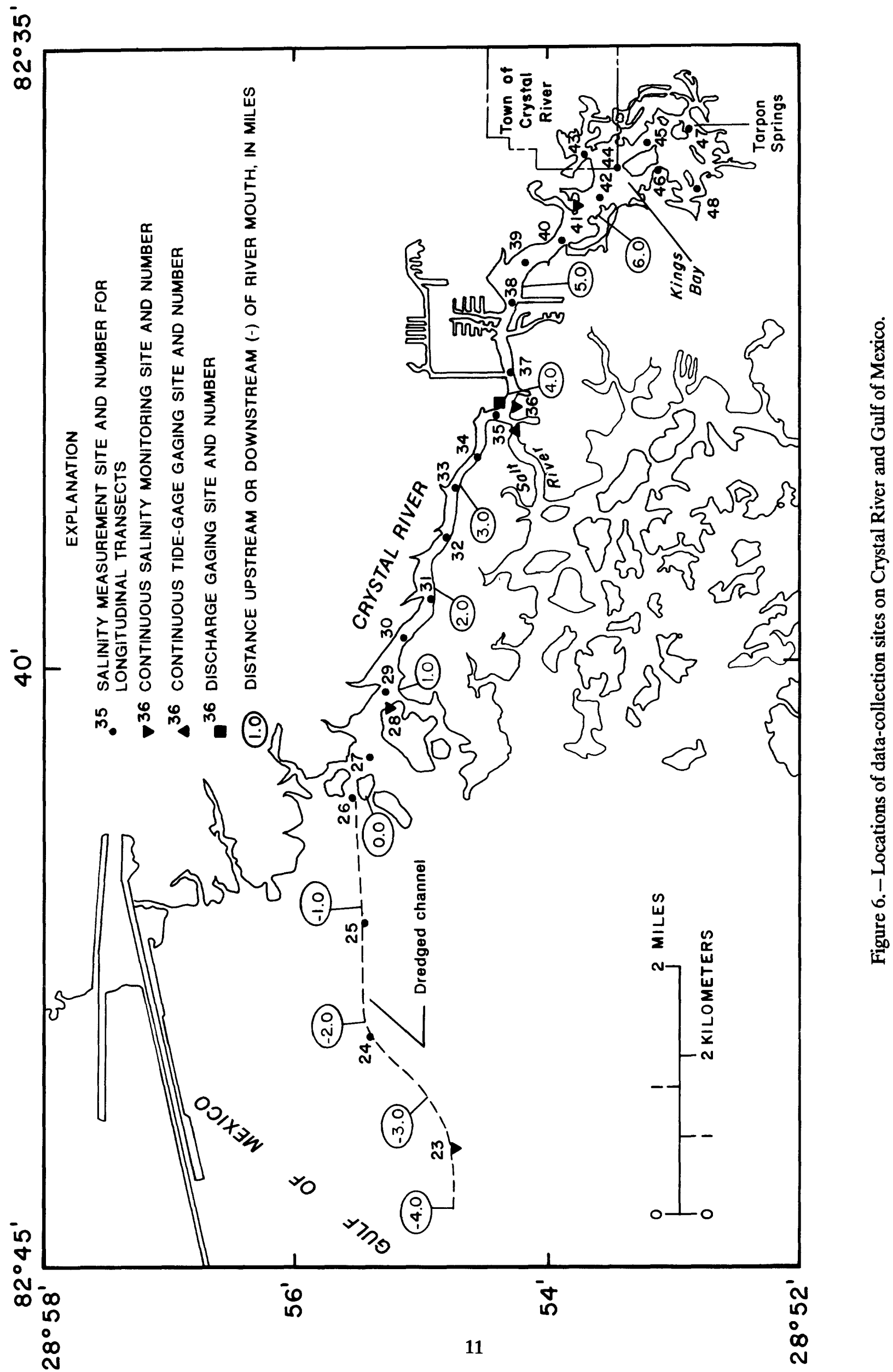




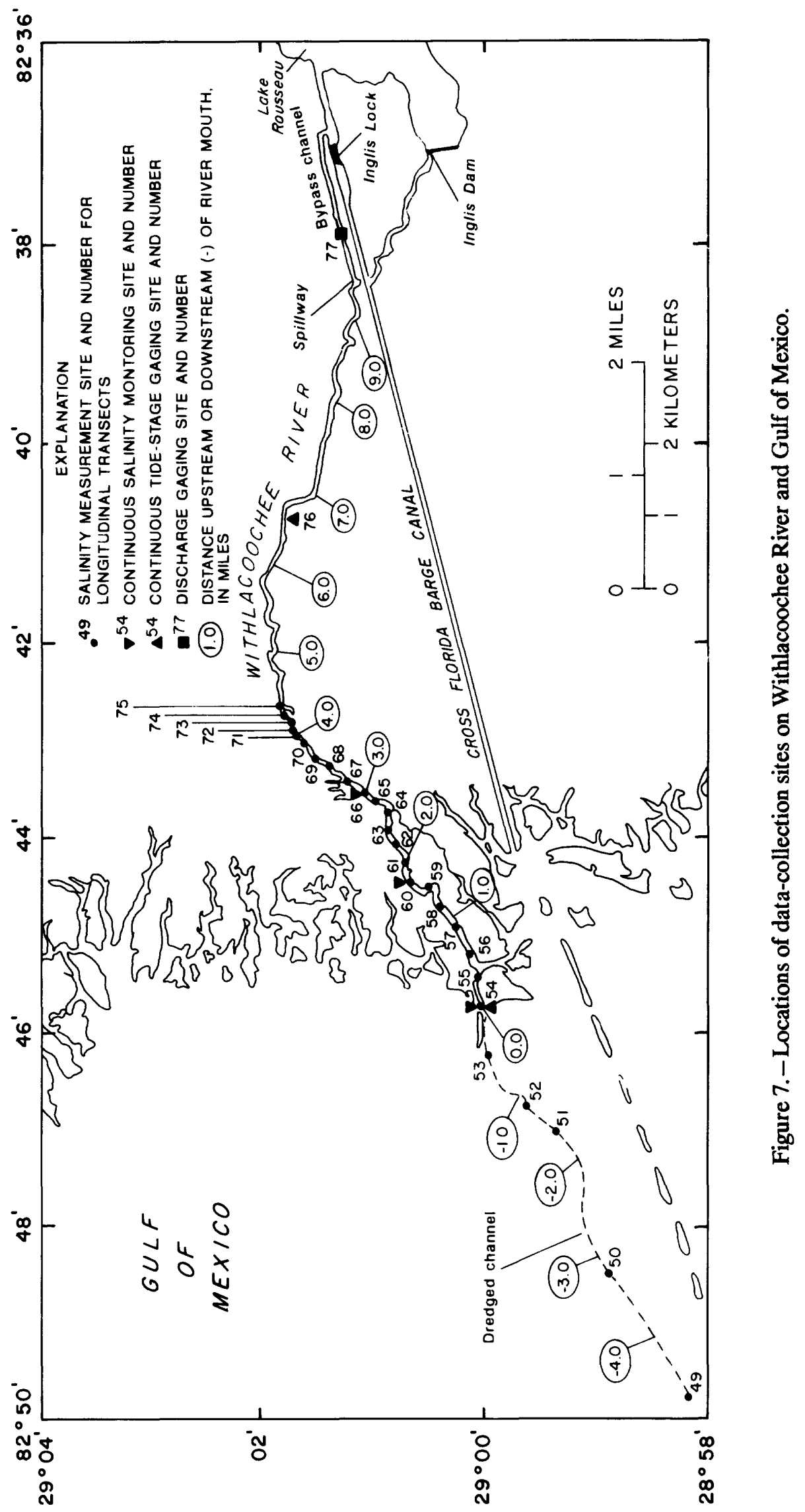


were equipped with instruments that measured and recorded data at 15 -minute intervals. Specific conductance was measured in microsiemens per centimeter and readings were compensated to a temperature of $25^{\circ} \mathrm{C}$. Specific conductance, in microsiemens per centimeter, was converted to salinity, in parts per thousand, based upon a U.S. Geological Survey statistical program (R.L. Miller, U.S. Geological Survey, written commun., 1984) (table 3).

\section{Table 3. - Conversions from specific conductance to salinity}

[Compensated to a temperature of 25 degrees Celsius]

\begin{tabular}{cc}
\hline $\begin{array}{c}\text { Specific conductance, } \\
\text { in microsiemens per } \\
\text { centimeter }\end{array}$ & $\begin{array}{c}\text { Salinity, } \\
\text { in parts per } \\
\text { thousand }\end{array}$ \\
\hline 452 & 0.3 \\
936 & .5 \\
1,940 & 1.0 \\
3,785 & 2.0 \\
4,675 & 2.5 \\
5,500 & 3.0 \\
8,945 & 5.0 \\
13,040 & 7.5 \\
17,000 & 10.0 \\
20,870 & 12.5 \\
24,660 & 15.0 \\
28,370 & 17.5 \\
29,200 & 18.0 \\
32,040 & 20.0 \\
35,640 & 22.5 \\
39,200 & 25.0 \\
42,710 & 27.5 \\
46,180 & 30.0 \\
\hline
\end{tabular}

Tide stage was continuously monitored at stations located 0.05 and 2.2 miles upstream of the mouth of Weeki Wachee River (fig. 5, sites 5 and 17), 3.9 miles upstream of the mouth of Crystal River (fig. 6, site 36), and 0.0 and 6.6 miles upstream of the mouth of the Withlacoochee River (fig. 7, sites 54 and 76). Records for stations near the river mouths (sites 5, 36, and 54) were used for analysis in this report.

Two continuous-record specific-conductance stations were installed in the Weeki Wachee River. One instrument was installed at the mouth of the river (fig. 5, site 5) and was operated from May 1982 to November 1985. The sensor was about 100 feet from the bank of the river in about 6 feet of water and about 1 foot above the river bottom. The second instrument was installed 1.37 miles upstream of the mouth of the river (fig. 5, site 12). The sensor was at the riverbank about 1 foot above the river bottom in about 4 feet of water and was operated from June 1984 to January 1986. The recording interval of the sensor at the mouth ranged from 0.3 to $40.3 \mathrm{ppt}$, and the recording interval of the sensor at the upper site ranged from 0.2 to 18.5 ppt.

Salinity was monitored continuously at four locations in the Crystal River Estuary. One station was in the Gulf of Mexico about 3.5 miles offshore of the river mouth (fig. 6, site 23) and was operated from June 1984 to August 1985. The sensor was about 1 foot above the bottom in about $\mathbf{1 0}$ feet of water. The second station was 3.92 miles upstream of the river mouth (fig. 6, site 36) and was operated from July 1982 to November 1985. The sensor was placed near the riverbank about 1 foot above the river bottom in about 8 feet of water. The third station was $\mathbf{5 . 9 2}$ miles upstream of the river mouth (fig. 6, site 41) and was operated from March 1984 to March 1986. The sensor was placed near the riverbank in about 6 feet of water and about 1 foot above the river bottom. The fourth station (fig. 6, site 28 ) was 0.9 mile upstream of the river mouth and was operated during July and August 1985 . The limits of salinity measured by the probes at sites 28 and 23 ranged from 0.3 to $40.3 \mathrm{ppt}$, from 0.2 to 18.5 ppt at site 36 , and from 0.1 to $8.7 \mathrm{ppt}$ at site 41 .

Three continuous-recording specificconductance monitors for determining salinity were installed in the Withlacoochee River. One station was at the river mouth (fig. 7, site 54) and was operated from March 1984 to January 1986. The sensor was at the riverbank about 1 foot above the river bottom in about 5 feet of water. The second station (fig. 7 , site 60 ) was 1.70 miles upstream of the river mouth. The sensor probe was about 1 foot above the river bottom in about 4 feet of water and about 50 feet from the riverbank. The station was operated from May 1984 to September 1985. The third station (fig. 7, site 66) was 2.96 miles upstream of the river mouth and was operated from March 1984 to September 1985. The sensor was placed along the river channel about 50 feet from the bank in about 8 feet of water. The recorded range of salinity at the mouth (site 54) was 0.3 to $40.3 \mathrm{ppt}$ and at the middle (site 60) and upper (site 66) sites was 0.2 to 18.5 ppt. 
Data necessary to gage discharge on the Weeki Wachee River were collected at a site 0.7 mile downstream of the main spring (fig. 5, site 18) and were attempted at site $17,2.2$ miles upstream of the mouth of the river (fig. 5). At the upper site, individual discharge measurements were made every other month. At site 17, an electromagnetic velocity meter was installed, and several sets of continuous tidal cycle discharge measurements were made to develop a mean velocity-point velocity relation. Development of the relation was unsuccessful due to changing stage and velocity relations caused by accumulation of aquatic vegetation.

Discharge data were collected on Crystal River about 3 miles downstream from Kings Bay (fig. 6, site 36) at the site of a prior gaging station. An electromagnetic velocity meter was installed, and two sets of continuous tidal discharge measurements were made to develop streamflow rating curves for the velocity meter. Due to fouling of the velocity meter caused by accumulations of aquatic vegetation on the meter and equipment failures, computation of daily discharge was limited to times when the meter was operating satisfactorily. These periods usually coincided with periods when salinity distribution data were being collected in the estuary. River stage, for determining discharge for the Withlacoochee River, was monitored at an existing gaging station on the bypass channel (fig. 7, site 77) 10 miles upstream of the river mouth.

Supplemental salinity data were collected by making measurements from a boat at sites along longitudinal transects that extended from the Gulf of Mexico to the upstream extent of saltwater intrusion in each of the three rivers (table 4). Measurements were made during different river discharges and high-tide conditions. All river distances used in this report are computed from the mouth, river mile 0.0 , which was established where the river mouth ended in the gulf. Salinity was measured using a portable multiparameter water-quality monitoring instrument. The equipment was calibrated in the laboratory prior to the start of each field trip.

Salinity data along the longitudinal transects were collected several times during a rising tide. The first run started close to low water and the last run ended near high water when maximum intrusion occurred. At salinity measurement stations, readings were taken at 1- or 2-foot intervals from near water surface to near the river-channel bottom. These measurements were made on days of predicted extreme monthly tides (U.S. Department of Commerce, 1985). Because tides are generally highest in summer, these measurements were made at more frequent intervals during this time.

\section{Data Analysis}

Data collected during the salinity runs were used to show the relation among high-tide stage, river discharge, and salinity. The relation was developed using linear-regression analysis, a statistical approach that determines a best-fit equation between one dependent variable and one or more independent variables. The location of the upstream extent of the salinity was used as the dependent variable, and river discharge and high-tide stage were used as the independent variables. The salinity that represents the upstream extent of the zone of saltwater intrusion $(0.5$ or $2.0 \mathrm{ppt})$ and the more saline $5-, 18-$, and 25-ppt salinities were selected as reference indicators of salinity intrusion.

The upstream location of the salinity lines was determined from longitudinal profiles drawn by linear interpolations between sampling points. The point of maximum intrusion was then determined by taking a vertically averaged reading of each salinity line, and regression equations were developed for the location of a point where the vertically averaged salinity equals that salinity at high tide. For the Withlacoochee River, equations also were developed for the location where the 5- and 0.5-ppt salinities intersect the water surface and river bottom.

Application of the regression approach to the Weeki Wachee, Crystal, and Withlacoochee River Estuaries was complicated by several factors. One factor is that salinities near the river mouths are affected by the large-scale circulation and littoral drift processes in the Gulf of Mexico. Another factor is that some spring flow to the coastal rivers is tidally influenced, and accurate flow determinations were difficult. A third factor is that spring flow, controlled by water levels and gradients within the Upper Floridan aquifer, varies more slowly and over a much smaller range than rivers of similar size that respond to rainfallrunoff events. Consequently, the range of salinity movement due to natural variations in coastal rivers inflow was smaller than those studied by Giovannelli (1981) and Fernandez (1985). 
Table 4. - Description of observation sites

[S, salinity; TS, tide stage; $Q$, discharge; negative sign (-) indicates downstream of river mouth; - , no data]

\begin{tabular}{|c|c|c|c|c|c|c|c|c|}
\hline \multicolumn{3}{|c|}{ Weeki Wachee River } & \multicolumn{3}{|c|}{ Crystal River } & \multicolumn{3}{|c|}{ Withlacoochee River } \\
\hline $\begin{array}{l}\text { Index } \\
\text { number } \\
\text { (fig. 5) }\end{array}$ & $\begin{array}{c}\text { Distance } \\
\text { relative to } \\
\text { mouth (miles) }\end{array}$ & $\begin{array}{l}\text { Param- } \\
\text { eters } \\
\text { measured }\end{array}$ & $\begin{array}{c}\text { Index } \\
\text { number } \\
\text { (fig. 6) }\end{array}$ & $\begin{array}{l}\text { Distance } \\
\text { relative to } \\
\text { mouth (miles) }\end{array}$ & $\begin{array}{l}\text { Param- } \\
\text { eters } \\
\text { measured }\end{array}$ & $\begin{array}{c}\text { Index } \\
\text { number } \\
\text { (fig. } 7 \text { ) }\end{array}$ & $\begin{array}{c}\text { Distance } \\
\text { relative to } \\
\text { mouth (miles) }\end{array}$ & $\begin{array}{l}\text { Param- } \\
\text { eters } \\
\text { measured }\end{array}$ \\
\hline $\begin{array}{l}1 \\
2 \\
3 \\
4 \\
5\end{array}$ & $\begin{array}{r}-3.66 \\
-2.70 \\
-1.60 \\
-.47 \\
.05\end{array}$ & $\begin{array}{c}\mathbf{S} \\
\mathbf{S} \\
\mathbf{S} \\
\mathbf{S} \\
\mathbf{S}, \mathbf{T S}\end{array}$ & $\begin{array}{l}23 \\
24 \\
25 \\
26 \\
27\end{array}$ & $\begin{array}{r}-3.50 \\
-2.20 \\
-1.15 \\
-.15 \\
.45\end{array}$ & $\begin{array}{l}S \\
S \\
S \\
S \\
S\end{array}$ & $\begin{array}{l}49 \\
50 \\
51 \\
52 \\
53\end{array}$ & $\begin{array}{r}-4.70 \\
-3.30 \\
-1.60 \\
-1.10 \\
-.47\end{array}$ & $\begin{array}{l}S \\
S \\
S \\
S \\
S\end{array}$ \\
\hline $\begin{array}{r}6 \\
7 \\
8 \\
9 \\
10\end{array}$ & $\begin{array}{r}.24 \\
.51 \\
.62 \\
.80 \\
1.00\end{array}$ & $\begin{array}{l}\mathbf{S} \\
\mathbf{S} \\
\mathbf{S} \\
\mathbf{S} \\
\mathbf{S}\end{array}$ & $\begin{array}{l}28 \\
29 \\
30 \\
31 \\
32\end{array}$ & $\begin{array}{r}.90 \\
1.02 \\
1.45 \\
1.88 \\
2.50\end{array}$ & $\begin{array}{l}\mathbf{S} \\
\mathbf{S} \\
\mathbf{S} \\
\mathbf{S} \\
\mathbf{S}\end{array}$ & $\begin{array}{l}54 \\
55 \\
56 \\
57 \\
58\end{array}$ & $\begin{array}{r}0.00 \\
.25 \\
.59 \\
.82 \\
1.11\end{array}$ & $\begin{array}{c}\text { S,TS } \\
\mathbf{S} \\
\mathbf{S} \\
\mathbf{S} \\
\mathbf{S}\end{array}$ \\
\hline $\begin{array}{l}11 \\
12 \\
13 \\
14 \\
15\end{array}$ & $\begin{array}{l}1.20 \\
1.37 \\
1.50 \\
1.74 \\
1.82\end{array}$ & $\begin{array}{l}\mathbf{S} \\
\mathbf{S} \\
\mathbf{S} \\
\mathbf{S} \\
\mathbf{S}\end{array}$ & $\begin{array}{l}33 \\
34 \\
35 \\
36 \\
37\end{array}$ & $\begin{array}{l}2.92 \\
3.92 \\
3.77 \\
3.92 \\
4.23\end{array}$ & $\begin{array}{c}\mathbf{S} \\
\mathbf{S} \\
\mathbf{S} \\
\mathbf{S}, \mathbf{S}, Q\end{array}$ & $\begin{array}{l}59 \\
60 \\
61 \\
62 \\
63\end{array}$ & $\begin{array}{l}1.46 \\
1.70 \\
2.00 \\
2.20 \\
2.38\end{array}$ & $\begin{array}{l}S \\
S \\
S \\
S \\
S\end{array}$ \\
\hline $\begin{array}{l}16 \\
17 \\
18 \\
19 \\
20\end{array}$ & $\begin{array}{c}1.89 \\
2.20 \\
6.80 \\
- \\
-\end{array}$ & $\begin{array}{c}\mathbf{S} \\
\mathbf{T S} \\
\mathbf{Q} \\
\mathbf{S} \\
\mathbf{S}\end{array}$ & $\begin{array}{l}38 \\
39 \\
40 \\
41 \\
42\end{array}$ & $\begin{array}{l}4.92 \\
5.22 \\
5.63 \\
5.92 \\
6.16\end{array}$ & $\begin{array}{l}\mathbf{S} \\
\mathbf{S} \\
\mathbf{S} \\
\mathbf{S} \\
\mathbf{S}\end{array}$ & $\begin{array}{l}64 \\
65 \\
66 \\
67 \\
68\end{array}$ & $\begin{array}{l}2.60 \\
2.47 \\
2.96 \\
3.21 \\
3.45\end{array}$ & $\begin{array}{l}\text { S } \\
\mathbf{S} \\
\mathbf{S} \\
\mathbf{S} \\
\mathbf{S}\end{array}$ \\
\hline \multirow[t]{2}{*}{$\begin{array}{l}21 \\
22\end{array}$} & - & $\begin{array}{l}\mathbf{S} \\
\mathbf{S}\end{array}$ & $\begin{array}{l}43 \\
44 \\
45 \\
46 \\
47\end{array}$ & $\begin{array}{l}- \\
- \\
- \\
-\end{array}$ & $\begin{array}{l}\mathbf{S} \\
\mathbf{S} \\
\mathbf{S} \\
\mathbf{S} \\
\mathbf{S}\end{array}$ & $\begin{array}{l}69 \\
70 \\
71 \\
72 \\
73\end{array}$ & $\begin{array}{l}3.56 \\
3.75 \\
3.89 \\
4.03 \\
4.18\end{array}$ & $\begin{array}{l}\mathbf{S} \\
\mathbf{S} \\
\mathbf{S} \\
\mathbf{S} \\
\mathbf{S}\end{array}$ \\
\hline & & & 48 & & $\mathbf{S}$ & $\begin{array}{l}74 \\
75 \\
76 \\
77\end{array}$ & $\begin{array}{l}4.28 \\
4.37 \\
6.60 \\
9.90\end{array}$ & $\begin{array}{c}\mathbf{S} \\
\mathbf{S} \\
\text { TS } \\
\mathbf{Q}\end{array}$ \\
\hline
\end{tabular}

These factors made it impossible to obtain satisfactory results relating the maximum upstream extent of the vertically averaged 25 - and 18-ppt salinities to river discharge and high tide. Consequently, locations of the vertically averaged 25- and 18-ppt salinities were estimated by simple linear regression between the salinity location and salinity recorded at the continuous-record stations at the mouths of the Weeki Wachee and Withlacoochee Rivers. The daily maximum salinity recorded at the reference station was used to compute the daily maximum upstream extent of the salinities. This approach, however, does not permit direct evaluations between discharge and migration of the vertically averaged 25 - and 18-ppt salinities. Similar evaluations in the Crystal River Estuary did not provide satisfactory results because the reference station was too far upstream and did not consistently correlate with salinity fluctuations in the Gulf of Mexico.

\section{PHYSICAL AND SALINITY CHARACTERISTICS}

\section{Weeki Wachee River}

The Weeki Wachee River heads at Weeki Wachee Springs in southwestern Hernando County and flows westerly, meandering through about 7 miles of lowlands to its confluence with Mud River (fig. 5). The estuary continues about 1 mile farther to the Gulf of Mexico at Bayport. Weeki Wachee Springs is a tourist attraction of national distinction and features underwater performances, swimming, and sightseeing boats.

The channel of Weeki Wachee River is narrow and winding and varies in width from about 25 to 200 feet, cutting 5 to 10 feet into the limestone of the underlying Upper Floridan aquifer. Artificial waterways with finger canals have been dredged tributary to the river (fig. 5), and much of the river downstream from river mile 3.4 has been 
widened and deepened. River flow is rapid in natural reaches of the river but becomes sluggish in areas where the channel has been enlarged. Movement of water in the canals is slight and occurs mainly because of tidal fluctuations.

The Weeki Wachee River is tidally affected to river mile 6.7 where a sand-bag control has been installed (Sinclair, 1978). Upstream from the control, the gradient is extremely flat. The river bottom intercepts sea level datum at mile 4.8. At the tide gage at river mile 2.20 , water levels normally fluctuate 1 to 2 feet compared to the tidal range of 3 to 4 feet in the gulf at the mouth of the river. The altitude of Weeki Wachee Springs varies between 9 and 11 feet above sea level.

The discharge of the Weeki Wachee River, based on the average of 364 individual measurements made between 1917 and 1974 at the gaging station downstream of the confluence with Little Springs (fig. 5), is $176 \mathrm{ft}^{3} / \mathrm{s}$. Observed flow has ranged between 101 and $275 \mathrm{ft}^{3} / \mathrm{s}$. Flow of the river is derived chiefly from Weeki Wachee Springs; however, along much of its course, the river is in hydrologic contact with the Upper Floridan aquifer, and many additional springs discharge into the river. Cherry and others (1970) estimated that these additional springs may contribute up to 20 percent more flow.

A unique stage-discharge relation for the long-term gaging site does not exist. Consequently, daily discharge of the river has been estimated from a relation between individual streamflow measurements and concurrent water levels in Weeki Wachee well 283201082315601 (fig. 8). The relation shows a good correlation; the square of the correlation coefficient $\left(R^{2}\right)$ for this regression equation is 0.87 , and the root mean square error (RMSE) is $\pm 11.6 \mathrm{ft}^{3} / \mathrm{s}$. All daily flow figures used for analysis are determined from the regression. Figure 8 shows that, for every 1 foot of water-level change in the well, a change of $12.4 \mathrm{ft}^{3} / \mathrm{s}$ of discharge occurs at the gaging site.

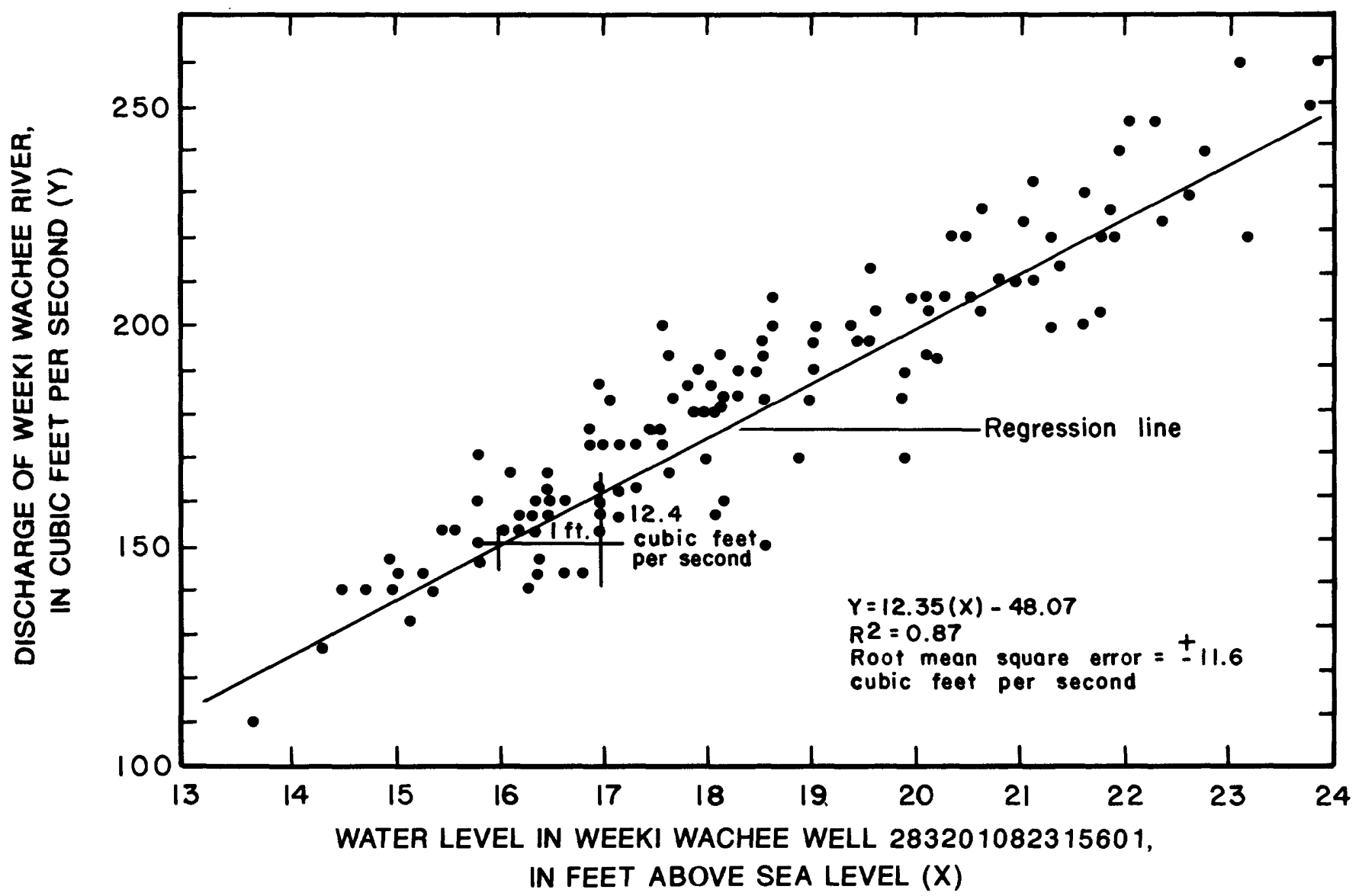

Figure 8. - Relation between discharge of Weeki Wachee River and water levels in Weeki Wachee well 283201082315601. 


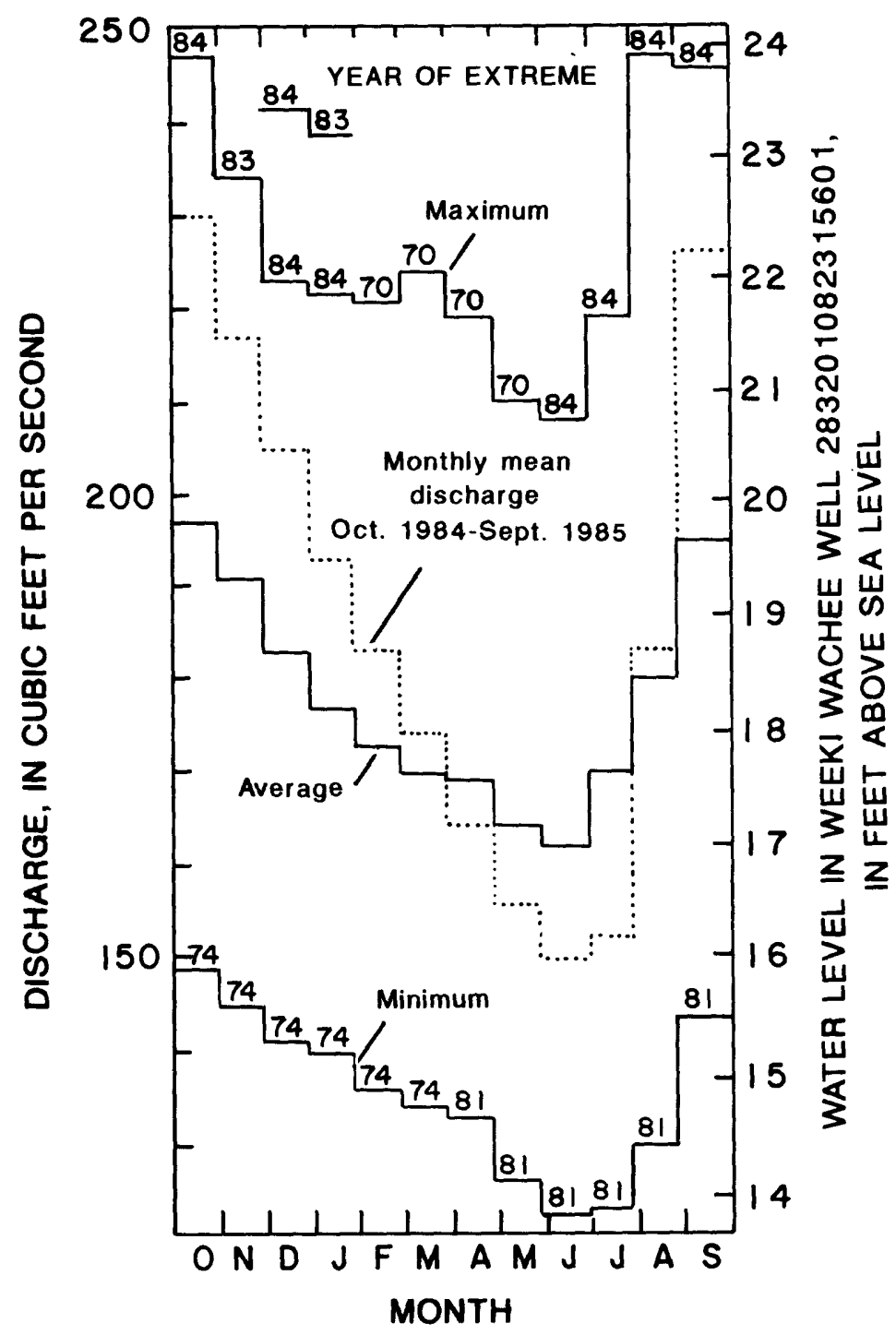

Figure 9.- Average, minimum, and maximum mean monthly discharges, 1966 through 1984, and monthly mean discharge, October 1984 through September 1985, for Weeki Wachee River.

Computed monthly mean discharges of Weeki Wachee River during October 1984 through September 1985 were compared with computed minimum, average, and maximum discharges for the 19-year period (1966-84) that records for the Weeki Wachee well are available (fig. 9). Monthly discharges were above average during October 1984 through March 1985 and August through September 1985. Discharges were below normal April through July 1985. Discharge is normally highest in September and
October at the end of the rainy season and lowest in June near the end of the dry season. Average discharge during the period of study was slightly higher than average discharge for the $1966-84$ period (fig. 9). Flow-duration curves showing the percent of days a daily discharge was equaled or exceeded during 1975-84 and the study period October 1984 through September 1985 are shown in figure 10. Discharges during the study period exceeded 1975-84 discharges 94 percent of the time. 


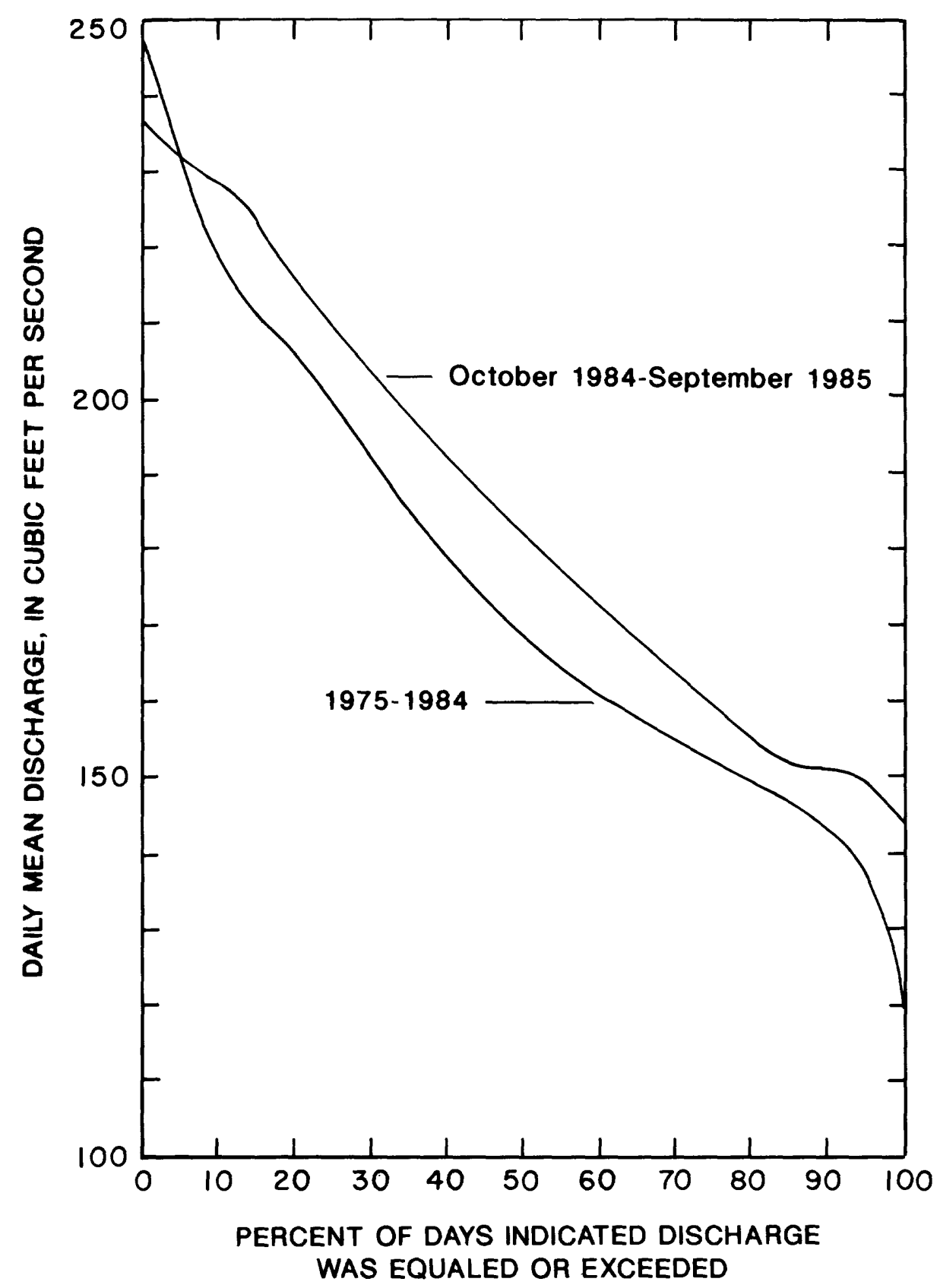

Figure 10. - Duration curves for computed daily mean discharge of Weeki Wachee River for 1975 through 1984 and October 1984 through September 1985.

The chemical characteristics of water from Weeki Wachee Springs and Salt Spring are shown in table 5. Water analysis of Weeki Wachee Springs indicates that the water is low in mineral content and is a calcium bicarbonate type with calcium the major constituent. Water from Salt Spring, which flows into Mud River then into Weeki Wachee River at river mile 0.80 , is high in mineral content and is a sodium chloride type with chloride the major constituent. It can be seen from table 5 that concentrations of most constituents are higher for Salt Spring than for Weeki Wachee Springs. The higher mineral content of Salt Spring probably is caused by saline water mixing with freshwater that discharges into the spring from the Upper Floridan aquifer. 
Table 5. - Chemical analysis of water from Weeki Wachee Springs and Salt Spring

[Concentrations are in milligrams per liter unless otherwise noted. $\mu \mathrm{S} / \mathrm{cm}$, microsiemens per centimeter, $\mathrm{ft}^{3} / \mathrm{s}$, cubic feet per second; - , no data; ${ }^{\circ} \mathrm{C}$, degrees Celsius. From Rosenau and others, 1977]

\begin{tabular}{|c|c|c|}
\hline Constituent & $\begin{array}{l}\text { Salt Spring, } \\
\text { August 6, 1965 }\end{array}$ & $\begin{array}{c}\text { Weeki Wachee } \\
\text { Springs, } \\
\text { May 13, } 1969\end{array}$ \\
\hline $\begin{array}{l}\text { Calcium (Ca) } \\
\text { Magnesium (Mg) } \\
\text { Sodium }(\mathrm{Na}) \\
\text { Potassium }(\mathrm{K}) \\
\text { Silica }\left(\mathrm{SiO}_{2}\right)\end{array}$ & $\begin{array}{c}56 \\
43 \\
260 \\
9.8 \\
6.6\end{array}$ & $\begin{array}{c}48 \\
5.0 \\
3.2 \\
5.0 \\
9.0\end{array}$ \\
\hline $\begin{array}{l}\text { Bicarbonate }\left(\mathrm{HCO}_{3}\right) \\
\text { Carbonate }\left(\mathrm{CO}_{3}\right) \\
\text { Sulfate }\left(\mathrm{SO}_{4}\right) \\
\text { Chloride }(\mathrm{Cl}) \\
\text { Fluoride }(\mathrm{F})\end{array}$ & $\begin{array}{r}160 \\
0 \\
73 \\
490 \\
.1\end{array}$ & $\begin{array}{r}160 \\
0 \\
9.6 \\
8.0 \\
.1\end{array}$ \\
\hline $\begin{array}{l}\text { Nitrate }\left(\mathrm{NO}_{3}\right) \\
\text { Dissolved solids }\end{array}$ & .50 & .10 \\
\hline $\begin{array}{l}\text { Calculated } \\
\text { Residue on evaporation } \\
\text { at } 180^{\circ} \mathrm{C}\end{array}$ & $\begin{array}{r}1,020 \\
-\end{array}$ & $\begin{array}{l}167 \\
180\end{array}$ \\
\hline Hardness as $\mathrm{CaCO}_{3}$ & 320 & 140 \\
\hline $\begin{array}{l}\text { Noncarbonate hardness } \\
\text { as } \mathrm{CaCO}_{3}\end{array}$ & 190 & 130 \\
\hline Alkalinity as $\mathrm{CaCO}_{3}$ & 130 & - \\
\hline $\begin{array}{l}\text { Specific conductance } \\
(\mu \mathrm{S} / \mathrm{cm})\end{array}$ & 1,800 & 275 \\
\hline $\begin{array}{l}\text { pH (units) } \\
\text { Discharge }\left(\mathrm{ft}^{3} / \mathrm{s}\right)\end{array}$ & $\begin{array}{r}7.3 \\
32.4\end{array}$ & $\begin{aligned} 8.0 \\
181\end{aligned}$ \\
\hline
\end{tabular}

Water in the Weeki Wachee River Estuary is characterized by vertical and longitudinal salinities that vary with tides and streamflow. Salinity distributions in a longitudinal section measured near the center of the river for various high-tide and streamflow conditions are shown in figure 11. Streamflows shown are the average daily discharge for the day of sampling. The tide stage is the high-tide stage recorded at river mile 0.05. Approximate locations of the lines of equal salinity were determined by linear interpolation between sampling points. The salinity profiles show salinity gradients becoming steeper with increasing distance upstream from the river mouth. The transition between gulf and river waters is narrow, and the waters are stratified vertically near the upstream extent of saltwater intrusion and more mixed away from the upstream extent of saltwater intrusion. Most stratification at high tide occurs within 0.5 mile of the upstream extent of saltwater intrusion. In this region, top-to-bottom ratios range from 0.90 at 0.5 mile from the upstream end of the saltwater intrusion to about 0.1 at 0.10 mile from the end (fig. 12). At distances greater than about 0.5 mile downstream from the edge of the salt front, ratios are generally greater than 0.95 , and salinity is virtually uniform from top to bottom.

Salinity in the Gulf of Mexico and along the Weeki Wachee River Estuary increases gulfward and varies considerably at a given location. Longitudinal variations in salinity recorded at high tide are shown in figure 13. Salinities varied from 17.5 to $29.1 \mathrm{ppt}$ about 3.7 miles offshore of the river mouth, from 5.0 to $17.9 \mathrm{ppt}$ at the river mouth, from 0.5 to $15.7 \mathrm{ppt}$ at river mile 1.2 , and from 0.3 to $5.0 \mathrm{ppt}$ at river mile 1.74 . The largest variation in salinity was observed in the reach between river miles 1.0 and 1.3. The data show a wide mixing zone and flat horizontal gradients from the gulf to about 1 mile inside the river mouth. Above mile 1.2, salinity gradients steepen, indicating a narrow transition between saltwater and freshwater.

The range in salinity location at high tide in the Weeki Wachee River Estuary varied and decreased with decreasing concentration. The location of low-concentration salinities appeared to be less sensitive to changes in flow and tide stage than high-concentration salinities. The range in the observed maximum upstream extent of selected salinities during the period of study is listed below:

\begin{tabular}{cccc}
\hline $\begin{array}{c}\text { Salinity, } \\
\text { in parts per } \\
\text { thousand }\end{array}$ & \multicolumn{3}{c}{$\begin{array}{c}\text { Maximum upstream extent of salinity, } \\
\text { in miles upstream or downstream (-) of the river mouth }\end{array}$} \\
\cline { 2 - 4 } Minimum & Maximum & Range \\
\hline 0.5 & 1.3 & 1.9 & 0.6 \\
5.0 & .0 & 1.7 & 1.7 \\
10.0 & -1.1 & 1.6 & 2.7 \\
15.0 & -2.5 & 1.2 & 3.7 \\
18.0 & -3.9 & .0 & 3.9 \\
20.0 & -4.8 & -.6 & 4.2 \\
\hline
\end{tabular}



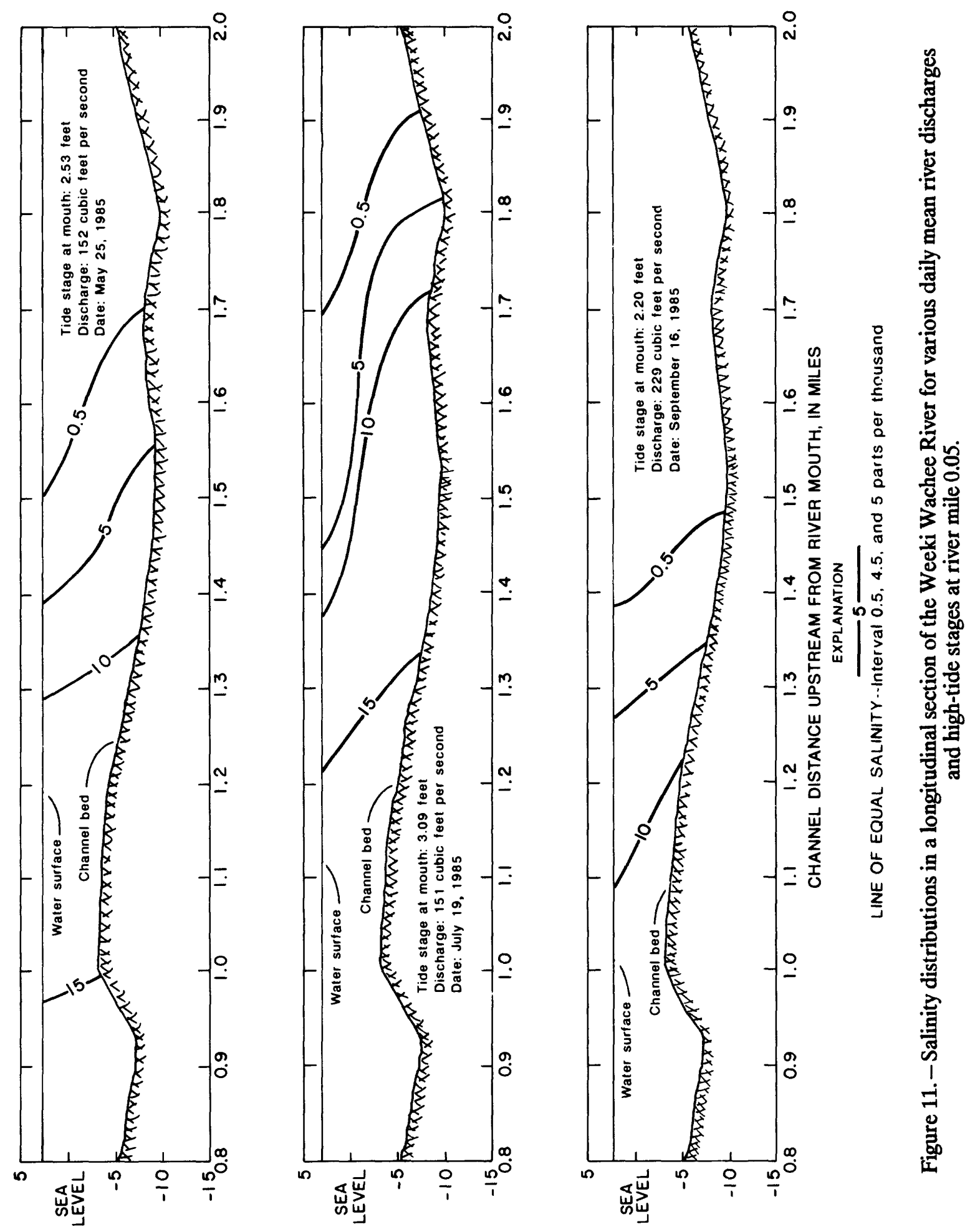

1 


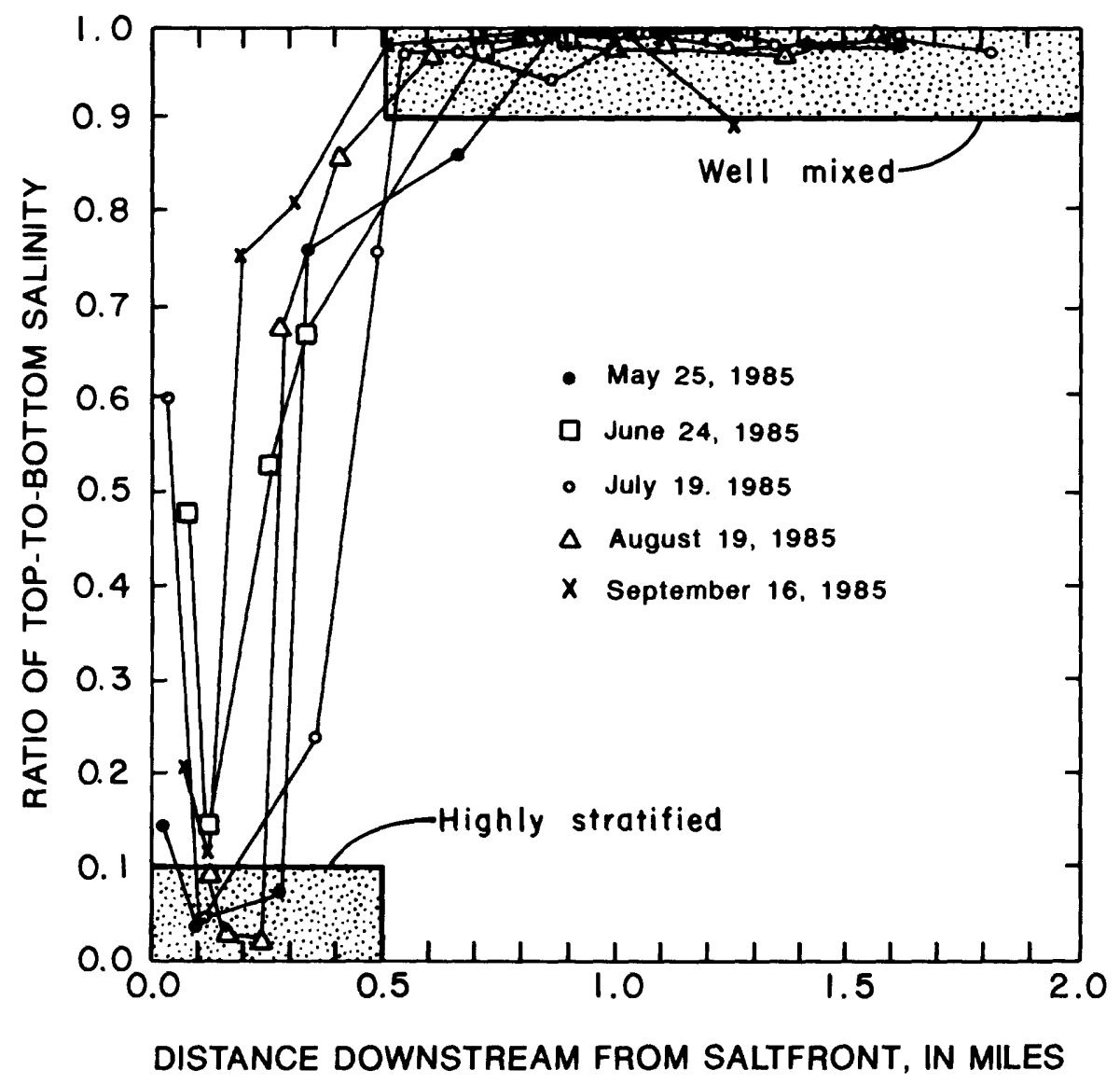

Figure 12.-Relation between ratio of top-to-bottom salinity to distance downstream from salt front at high-tide stages in the Weeki Wachee River.

The 20-ppt salinity had a range in movement that was about seven times as great as the range in movement of the 0.5 -ppt salinity.

The maximum saltwater intrusion (0.5-ppt salinity) at high tide was observed at river mile 1.91 at a discharge of $152 \mathrm{ft}^{3} / \mathrm{s}$ and a high-tide stage of 3.09 feet. The minimum saltwater intrusion was observed at river mile 1.25 at a streamflow of $209 \mathrm{ft}^{3} / \mathrm{s}$ and a high-tide stage of 2.33 feet. At streamflows of less than $190 \mathrm{ft}^{3} / \mathrm{s}$ and high-tide stages above 2.1 feet, the 0.5 -ppt salinity was found upstream of mile 1.5. At streamflows greater than $190 \mathrm{ft}^{3} / \mathrm{s}$ and high-tide stage of less than 2.7 feet, the 0.5 -ppt salinity did not reach mile 1.5. The range in location of the vertically averaged 0.5 -ppt salinity was smaller than expected considering the differences in discharge and tide stages.
Although it was expected that high streamflow and lower high tides would push saltwater gulfward, a consistent correlation was not observed between salinity in the lower section of the river and in the Gulf of Mexico with river discharge or high-tide stage. Figure 13 shows that, at comparable discharge rates in September 1983 and October 1984, salinities in October 1984 are considerably higher on a specific lower high tide than in September 1983 on a much higher high tide. One would expect that salinity concentration would be much higher on the higher high tide.

Salinity duration curves, computed from data of the continuous-monitoring sites at river miles 0.05 and 1.37 , are shown in figure 14. Salinity above $0.5 \mathrm{ppt}$ was detectable about 17 percent of the time at the upper station and was always present at the lower station. 


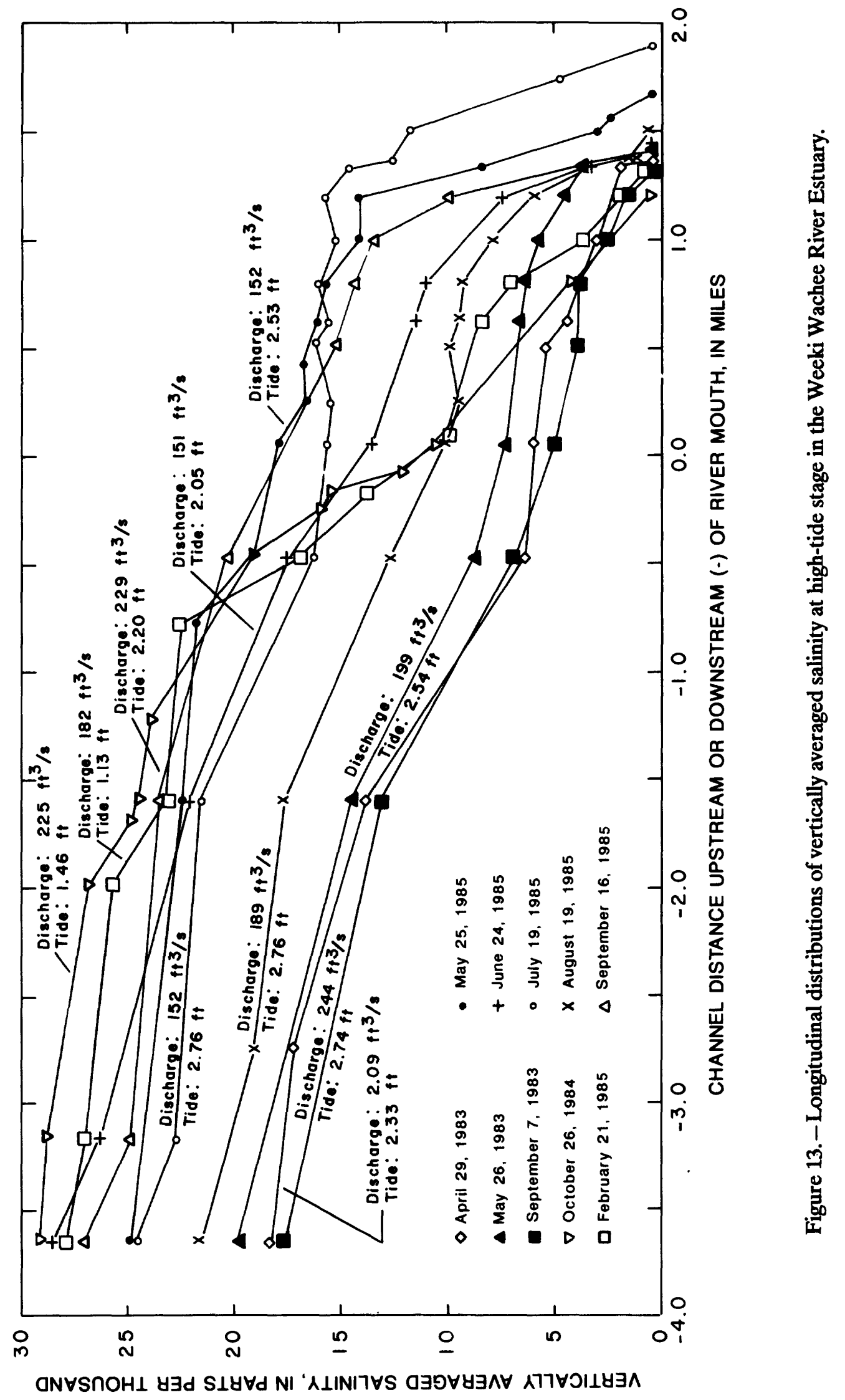




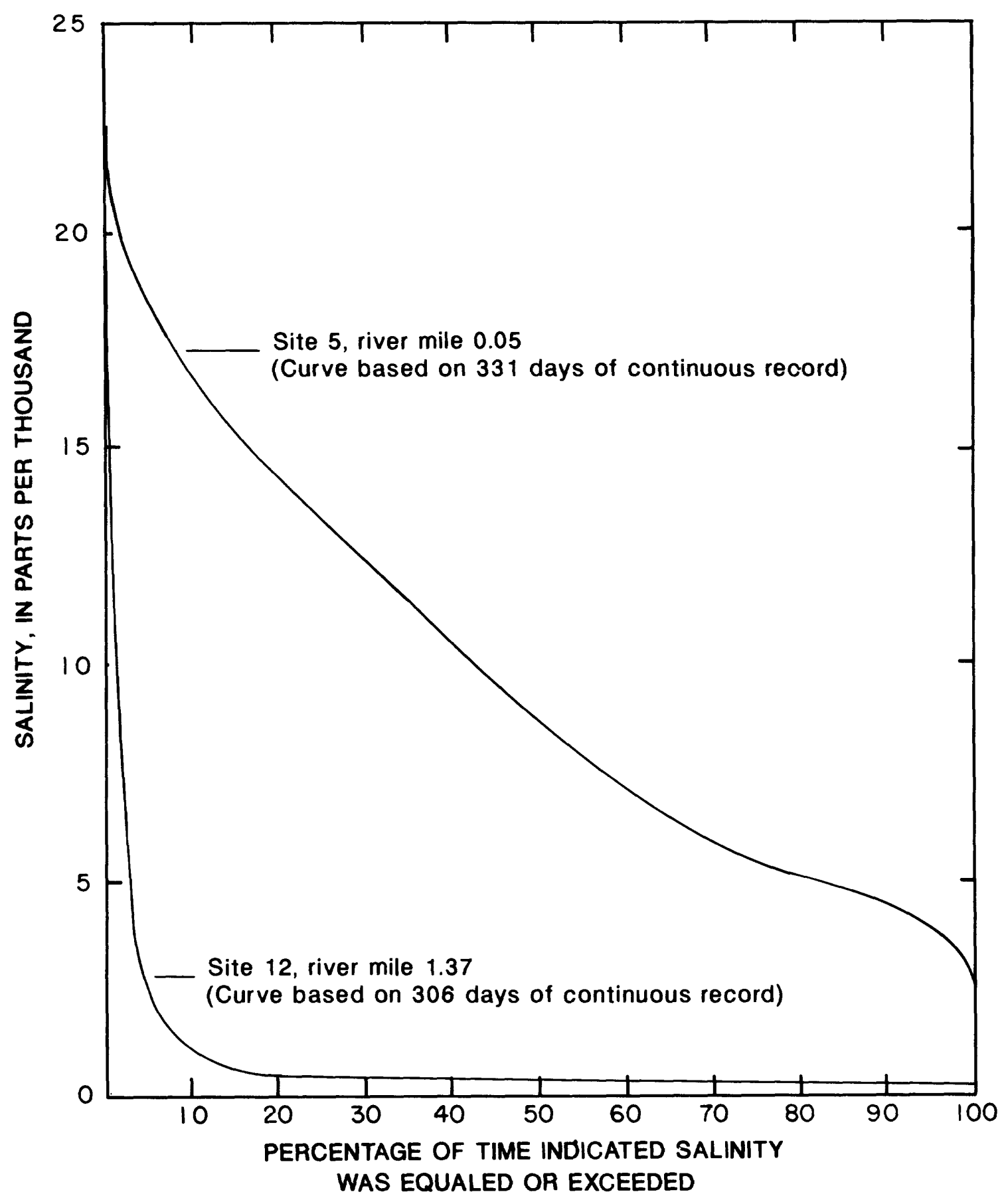

Figure 14. - Salinity duration curves for monitors at river miles 0.05 and 1.37 on the Weeki Wachee River, October 1984 through September 1985. 


\section{Crystal River}

Crystal River is in northwestern Citrus County near the town of Crystal River and flows northwesterly about 7 miles to the Gulf of Mexico. Headwaters of the river are in and around Kings Bay where flow originates from ground-water discharge from numerous springs and seeps that discharge into the river or into canals cut into the limestone bedrock (fig. 6). The headwater springs are topographically low and tidally affected, and spring vents are near the saltwater-freshwater transition zone of the Upper Floridan aquifer.

The channel of the Crystal River is about 400 to 2,000 feet wide and about 3 to 10 feet deep in Kings Bay and about 1,500 feet wide and 6 to 20 feet deep near the gulf. The river is full of submerged aquatic vegetation at its head, but aquatic plant growth diminishes gulfward. Land along much of the river is low lying and flat. Limestone and dolomite strata are present near land surface and generally are covered by a thin layer of sandy soil. Rock outcrops are prevalent along much of the river's course.

The average discharge of Crystal River, measured about 3 miles downstream from Kings Bay, was $975 \mathrm{ft}^{3} / \mathrm{s}$ for the 13-year period from 1965-77 and represents total spring discharge. Streamflow at this site is tidally affected, and water levels normally fluctuate 1.5 to 2.0 feet. Instantaneous discharge at a few individual springs in the headwaters has been measured, but most have not been measured because of their submarine nature (Rosenau and others, 1977). No significant inflows occur downstream of Salt River (Cherry and others, 1970).

Discharge records for Crystal River are rated poor. Stream-gaging conditions are less than ideal because of the effects of tides, aquatic vegetation, and the wide channel. Variation in mean monthly streamflow of Crystal River for the period 1965-77 is shown in figure 15. During summer and fall months, when rainfall and tides are high, river flow is low; and during winter and spring months, when rainfall and tides are low, flow is high. The anomalous timing of the flow of Crystal River is probably caused by seasonal tide (Mann and Cherry, 1969). The flow-duration curve of daily discharge for 1965-77 is shown in figure 16. The mean daily discharges exceeded 5 , 50 , and 95 percent of the time were $2,100,928$, and $38 \mathrm{ft}^{3} / \mathrm{s}$, respectively.

The magnitude and frequency of the estimated annual low flow of Crystal River are shown in table 6. Negative discharges occur due to tides. Negative flows could not be used in the usual log Pearson frequency distribution; therefore, the recurrence intervals were determined from a Gumbel frequency distribution plot. For periods greater than 14 days, when all discharges were positive, the log Pearson distribution was used to compute the recurrence-interval discharges.

The mineral content of water discharging from springs to Crystal River is variable but usually high. An analysis of water discharging from Tarpon Spring in the headwater of Kings Bay (table 7) indicates that the water is a mixture of two chemical types, calcium bicarbonate and sodium chloride. It reflects solution of carbonate rocks of the Upper Floridan aquifer and seawater from the Gulf of Mexico. The mineral content of water from the main spring at the head of Crystal River varied from 200 to $1,100 \mathrm{mg} / \mathrm{L}$, whereas the observed range of dissolved solids at the gaging station below the main spring in Crystal River (fig. 6, site 36 ) was 300 to 15,000 $\mathrm{mg} / \mathrm{L}$ during January 1964 through June 1976 (Mann and Cherry, 1969).

Table 6. - Low-flow frequencies of Crystal River at Cystal River, October 1964 to September 1977

\begin{tabular}{crrrr}
\hline $\begin{array}{c}\text { Period of } \\
\text { consecutive } \\
\text { days }\end{array}$ & \multicolumn{4}{c}{$\begin{array}{c}\text { Lowest average discharge, in cubic feet per second, for } \\
\text { indicated recurrence interval, in years }\end{array}$} \\
\cline { 2 - 5 } & 2 & 5 & 10 & 20 \\
\hline 1 & -670 & $-1,100$ & $-1,450$ & $-1,640$ \\
3 & -320 & -480 & -560 & -630 \\
7 & 50 & -200 & -270 & -300 \\
14 & 300 & 50 & 0 & -40 \\
30 & 470 & 330 & 270 & 230 \\
60 & 580 & 440 & 370 & 330 \\
90 & 630 & 480 & 420 & 380 \\
120 & 700 & 550 & 490 & 440 \\
183 & 820 & 660 & 590 & 540 \\
\hline
\end{tabular}




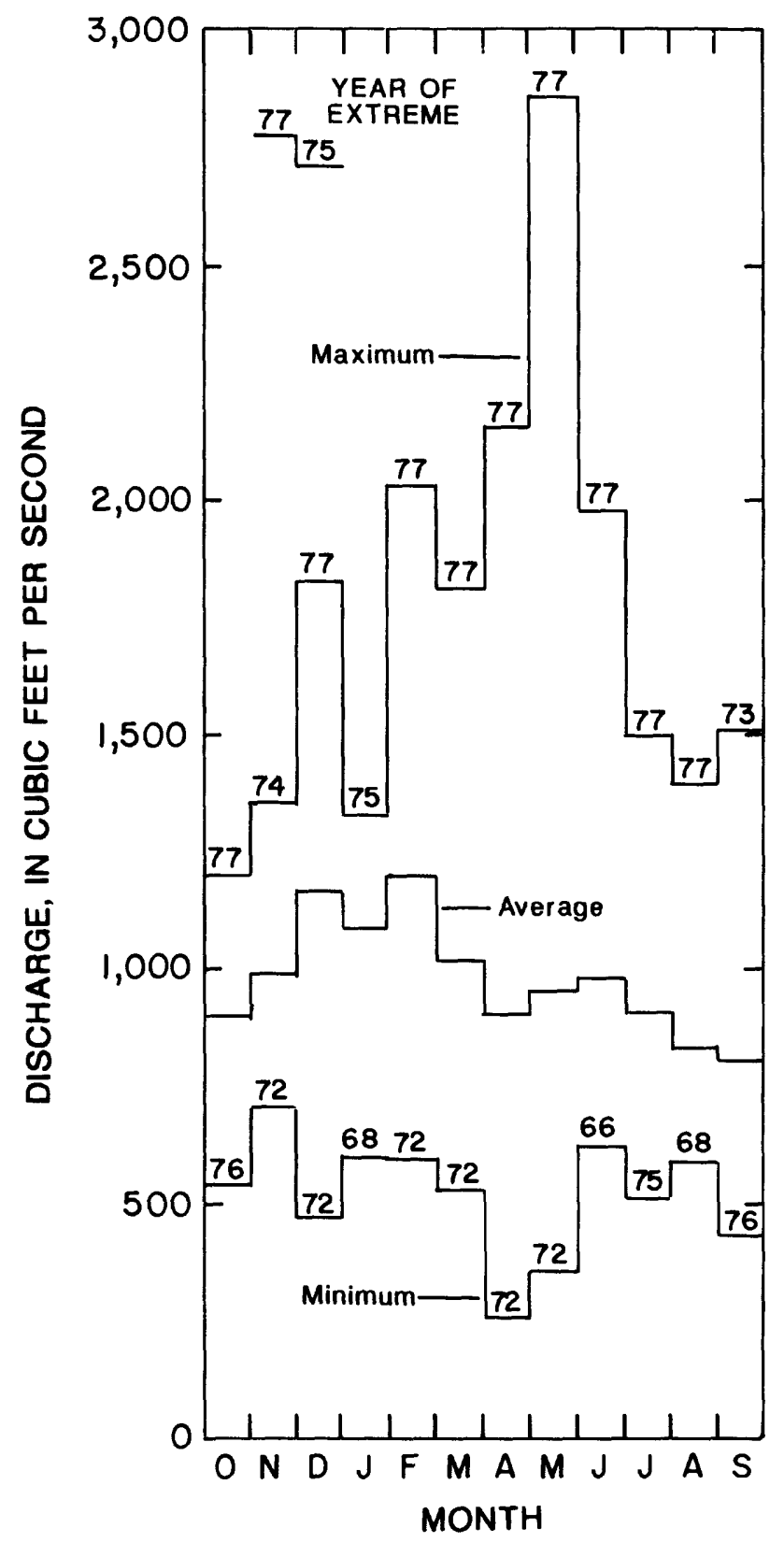

Figure 15. - Average, minimum, and maximum mean monthly discharges of the Crystal River (site 36), 1965 through 1977.

Longitudinal salinity profiles observed in Crystal River during different streamflow and high-tide stages are shown in figure 17. Daily streamflows shown are for the day prior to the sampling day to allow for a 1-day lag. The tide stage is the high-tide stage recorded at river mile 3.92. Data show a well-mixed estuary with some vertical stratification observed near the river mouth. The salinity in most verticals is virtually uniform from top to bottom and the transition between gulf and river waters is wide.

Vertical differences in salinity tend to increase as high-tide stage decreases. A comparison between high-tide stage and the ratio of top-tobottom salinity is shown in figure 18 . Lower ratios indicate increased stratification. Despite the scatter of points, the trend toward increased stratification with decreasing high-tide stage is evident. 


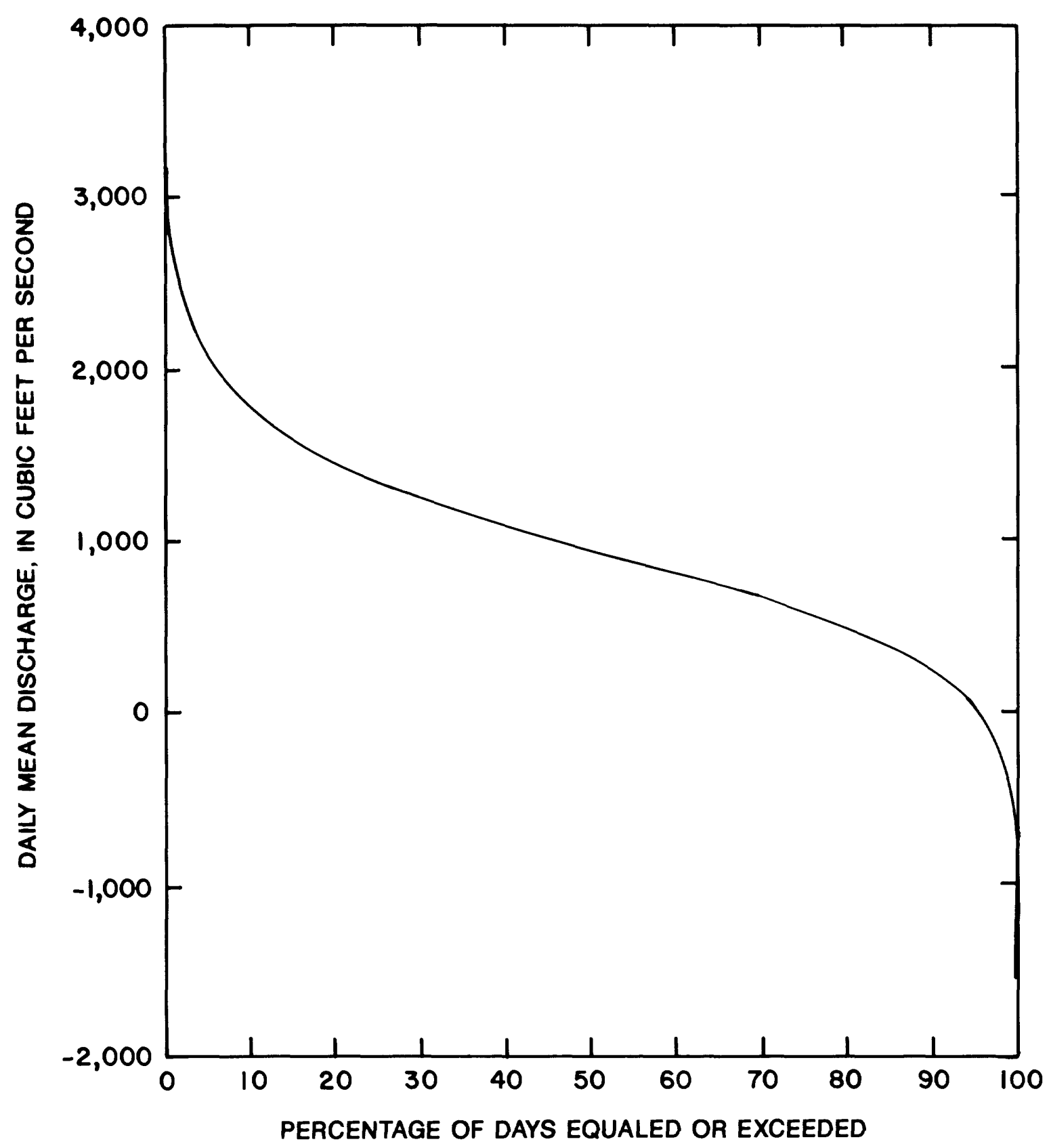

Figure 16. - Duration curve of daily mean discharges of Crystal River (site 36) for 1965 through 1977. 
Table 7. - Chemical analysis of water from Tarpon Spring in Kings Bay near Crystal River, January \&, 1975

[All values are in milligrams per liter except as noted. $\mu \mathrm{g} / \mathrm{L}$, micrograms per liter; $\mu \mathrm{S} / \mathrm{cm}$, microsiemens per centimeter. Modified from Rosenau and others, 1977]

\begin{tabular}{lc}
\hline \multicolumn{1}{c}{ Constituent } & Value \\
\hline Silica $\left(\mathrm{SiO}_{2}\right)$ & 7.2 \\
Iron $(\mu \mathrm{g} / \mathrm{L}$ as $\mathrm{Fe})$ & 10 \\
Calcium $(\mathrm{Ca})$ & 41 \\
Magnesium $(\mathrm{Mg})$ & 14 \\
Sodium $(\mathrm{Na})$ & 110 \\
Potassium $(\mathrm{K})$ & 3.9 \\
Sulfate $\left(\mathrm{SO}_{4}\right)$ & 29 \\
Chloride $(\mathrm{Cl})$ & 180 \\
Fluoride $(\mathrm{F})$ & 0.1 \\
Solids, sum of constituents & 447 \\
Hardness $(\mathrm{CaCO} 3)$ & 160 \\
Hardness, noncarbonate $(\mathrm{CaCO} 3)$ & 58 \\
Specific conductance $(\mu \mathrm{S} / \mathrm{cm})$ & 555 \\
Strontium, dissolved $(\mu \mathrm{g} / \mathrm{L}$ as Sr) & 290 \\
\hline
\end{tabular}

Salinity along the Crystal River Estuary decreased upstream and varied considerably at a given location. Longitudinal distributions of the vertically averaged salinity at high tide are shown in figure 19. Salinities ranged from 21 to $29 \mathrm{ppt}$ about 2 miles outside the river mouth, from 5 to $19 \mathrm{ppt}$ at river mile 1.0 , from 1 to $18 \mathrm{ppt}$ at river mile 2.92, and from 1 to 3 ppt at river mile 6.16. The largest variation in salinity was observed in the reach between river miles 1 and 4 .

The range in observed maximum upstream locations of selected salinities at high tide during the period of study is listed below:
The ranges are nearly the same for all but the 20-ppt salinity.

The maximum saltwater intrusion (2.0-ppt salinity) was observed at the head of the river in Kings Bay on numerous occasions. At flows of less than $640 \mathrm{ft}^{3} / \mathrm{s}$ and tide stages above $1.39 \mathrm{feet}$, the 2-ppt salinity was found upstream of river mile 5.3. At flows greater than $725 \mathrm{ft}^{3} / \mathrm{s}$ and hightide stages of less than 2.52 feet, the 2-ppt salinity did not reach river mile 4.0 and was at mile 2.18 at a flow of $1,399 \mathrm{ft}^{3} / \mathrm{s}$ and a tide stage of 0.82 foot. Minimum saltwater intrusion was observed on May 9, 1984, by Mote Marine Laboratory, Inc. ${ }^{1}$ (Southwest Florida Water Management District, written commun., 1985), at river mile 0.60 at a high-tide stage of 0.61 foot.

No consistent relation was observed between salinity in the gulf and daily streamflow or hightide stage. A comparison between the maximum upstream extent of the vertically averaged 25 - and 18-ppt salinities with discharge and high-tide stage of Crystal River for the period October 1984 through September 1985 is shown in figure 20. At times, the vertically averaged 25 -ppt salinity is located nearshore when discharge is high and tide stage low, whereas this salinity is sometimes located farther offshore when discharge is low and tide stage high.

Salinity duration curves for continuous-record sites at river miles 3.92 and 5.92 are shown in figure 21. Salinity above 2 ppt was present about 39 percent of the time at river mile 3.92 and about 6 percent of the time at river mile 5.92. The salinity, equaled or exceeded 10 percent of the time at river mile $3.92(6.1 \mathrm{ppt})$, was almost four times as great as the salinity at river mile $5.92(1.6 \mathrm{ppt})$.

\footnotetext{
${ }^{1}$ The use of firm names is for identification purposes only and does not constitute endorsement by the U.S. Geological Survey.
}

\begin{tabular}{cccc}
\hline $\begin{array}{c}\text { Salinity, } \\
\text { in parts per } \\
\text { thousand }\end{array}$ & \multicolumn{3}{c}{$\begin{array}{c}\text { Maximum upstream extent of salinity, } \\
\text { in miles upstream or downstream (-) of the river mouth }\end{array}$} \\
\cline { 2 - 4 } Minimum & Maximum & Range \\
\hline 2 & 0.6 & 6.2 & 5.6 \\
5 & -.1 & 5.5 & 5.6 \\
10 & -1.1 & 4.8 & 5.9 \\
15 & -2.1 & 3.9 & 6.0 \\
18 & -3.0 & 2.8 & 5.8 \\
20 & -3.5 & -.3 & 3.2 \\
\hline
\end{tabular}




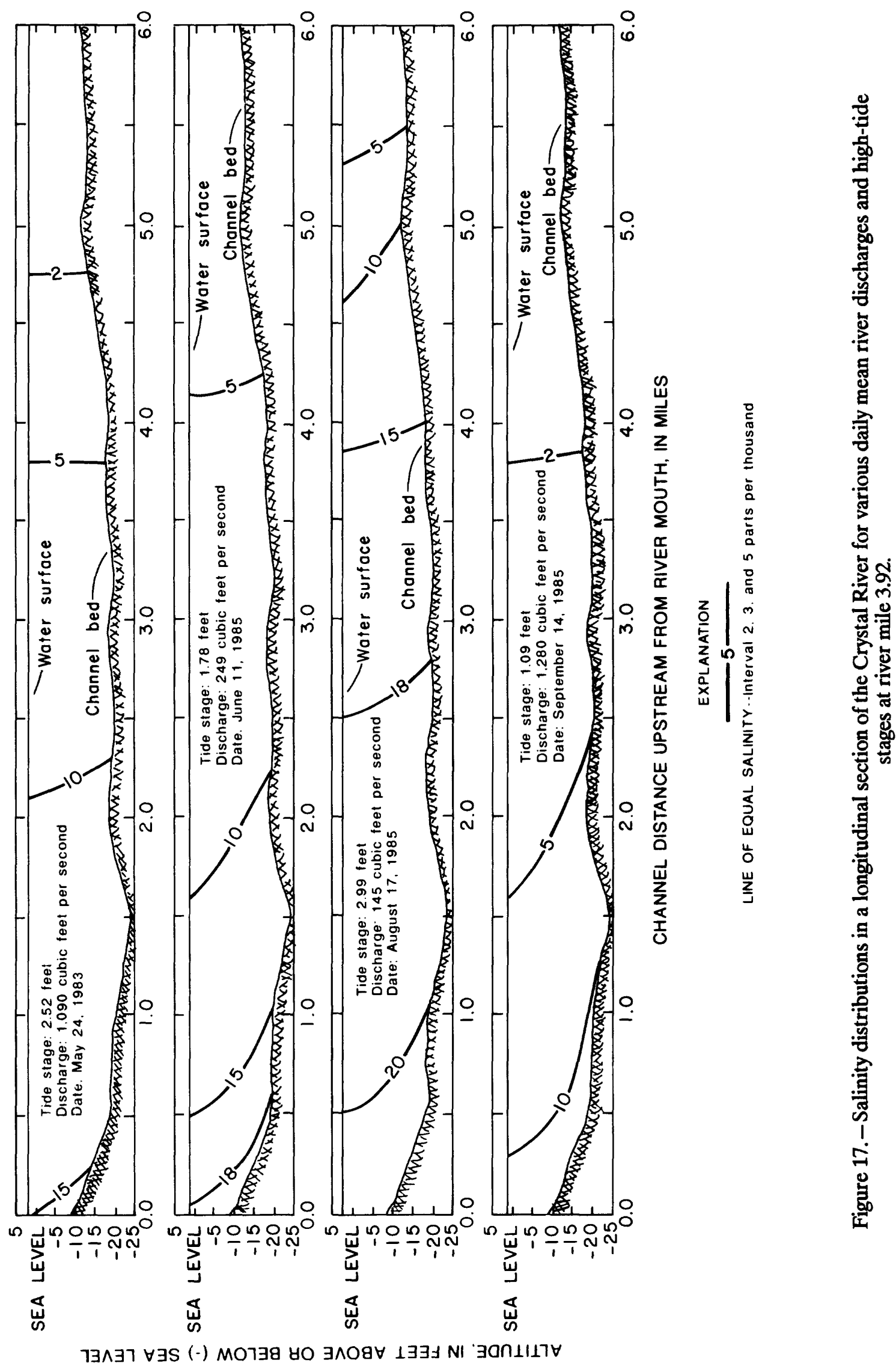




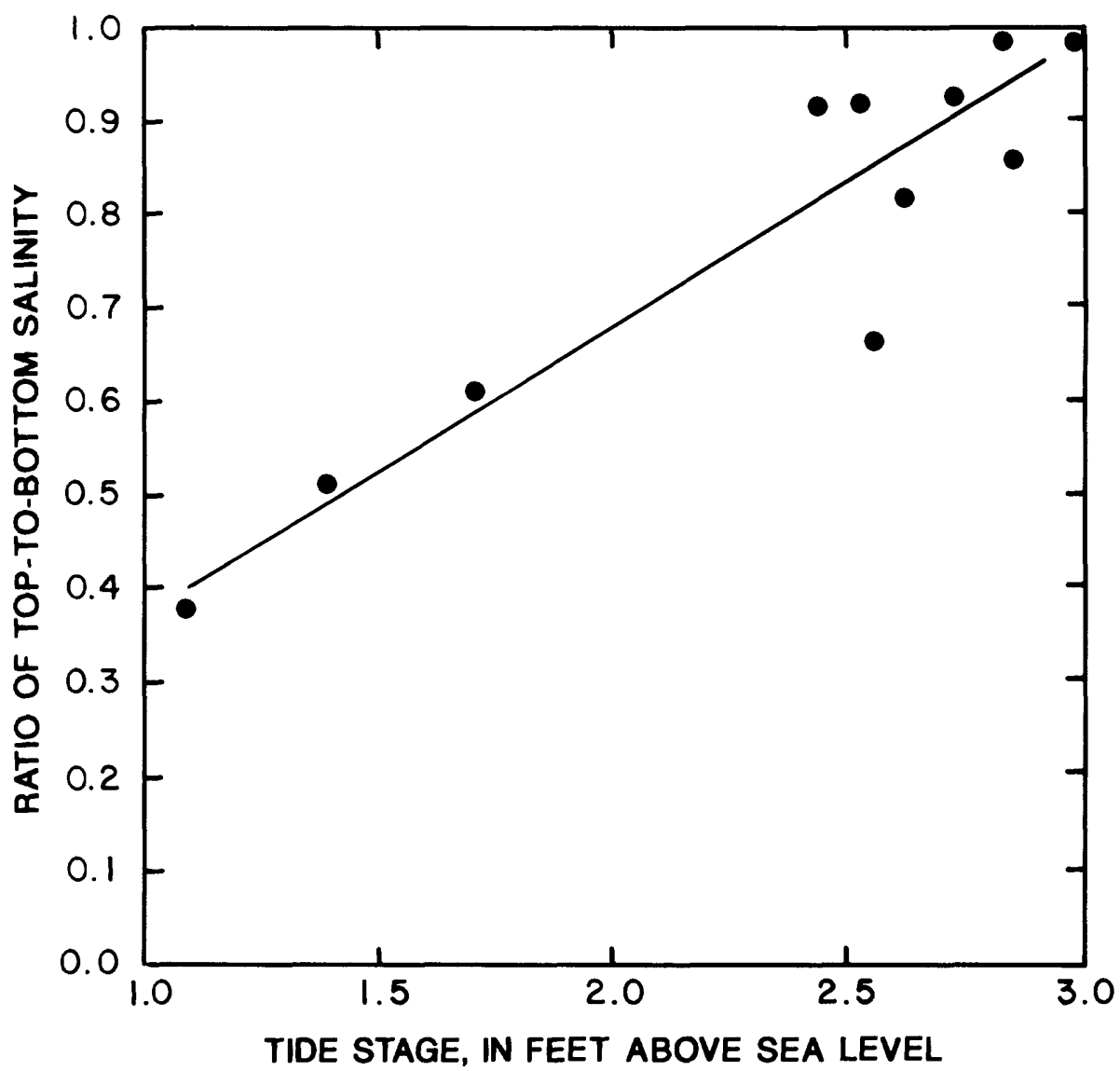

Figure 18. - Relation between ratio of top-to-bottom salinity at site 29 (river mile 0.90) and high-tide stage at Crystal River (site 36).

\section{Withlacoochee River}

The Withlacoochee River heads in the Green Swamp and flows northwesterly along the CitrusHernando County line to the Gulf of Mexico (fig. 1). Between the towns of Dunnellon and Inglis, about 11 miles upstream from the Gulf of Mexico, Inglis Dam forms Lake Rousseau (fig. 7). The dam was constructed in the early 1900's to impound water for electrical generation, but power generation was discontinued in 1965 when other facilities became available. The dam presently functions as a control structure that regulates the water level in Lake Rousseau and the discharge through Inglis Lock and a bypass channel. The lower reach of the river is further divided by the Cross Florida Barge Canal. This arrangement has existed since 1969 when Inglis Lock and the bypass channel were completed to provide freshwater in the lower section of the river between the canal and the gulf. The dam, the lock, and the spillway of the downstream end of the bypass channel control structures (fig. 7) effectively mark the practical upland extent of the river's estuarine zone.

Although water is discharged from Inglis Dam, from Inglis Lock, and from the bypass channel, most outflow passes through the bypass channel, except during flood flows. About 70 $\mathrm{ft}^{3} / \mathrm{s}$ of seepage occurs past Inglis Dam and the water used to operate the lock (German, 1978). At a lake-surface altitude of 27.5 feet above sea level, the bypass channel capacity is $1,540 \mathrm{ft}^{3} / \mathrm{s}$. Water is discharged through gates on the Inglis Dam to a channel that discharges to the Cross Florida Barge Canal, which, in turn, discharges to the gulf. As a result, all river flow to the Gulf of Mexico passes through control structures.

The channel of the lower Withlacoochee River is narrow, varying in width from about $\mathbf{5 0}$ to 350 feet, and cuts 15 to 20 feet into the limestone of the underlying Upper Floridan aquifer. The river is in hydrologic contact with the Upper Floridan aquifer, and depending on the relative stage of the river, water flows into or from the river (Sinclair, 1978). 


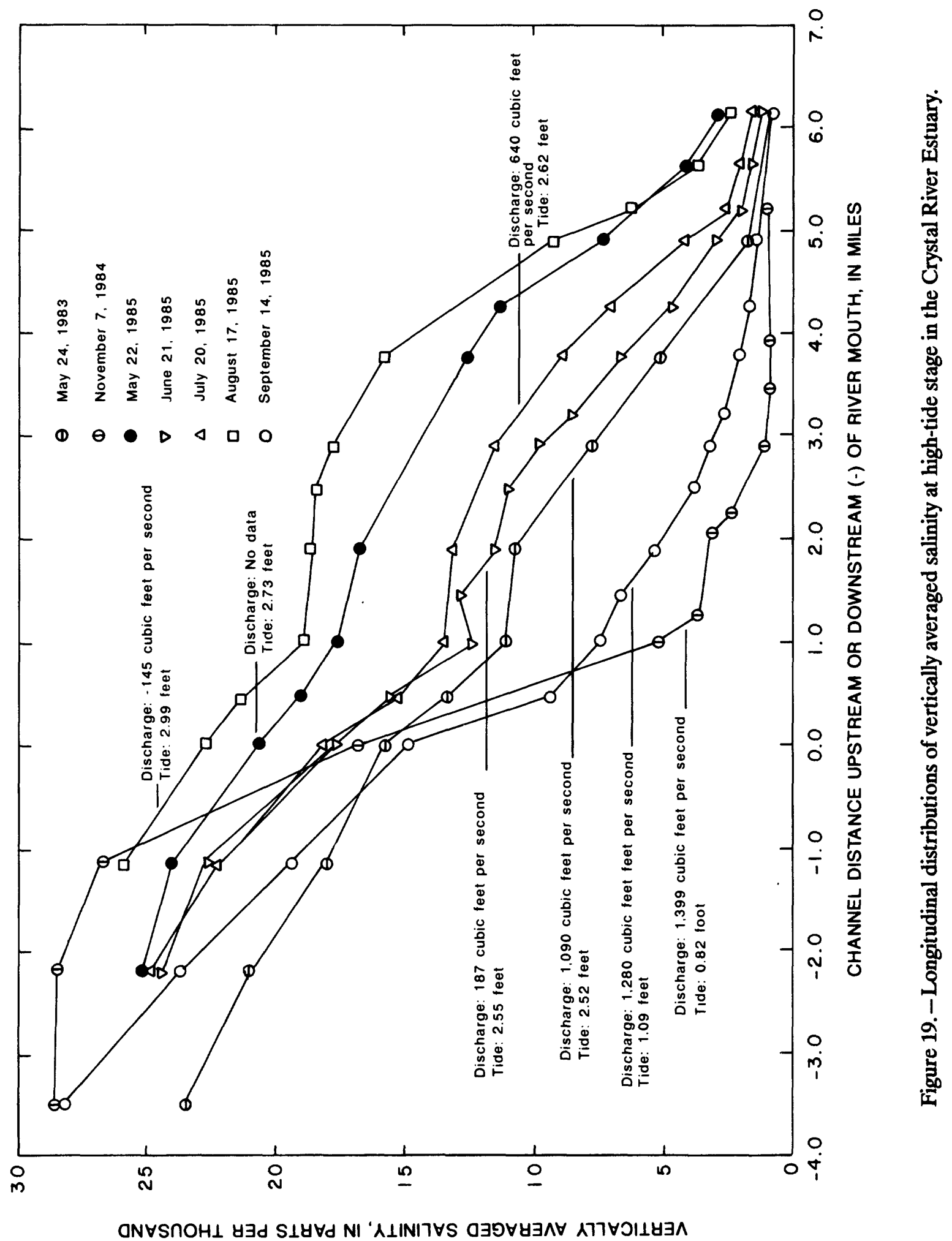



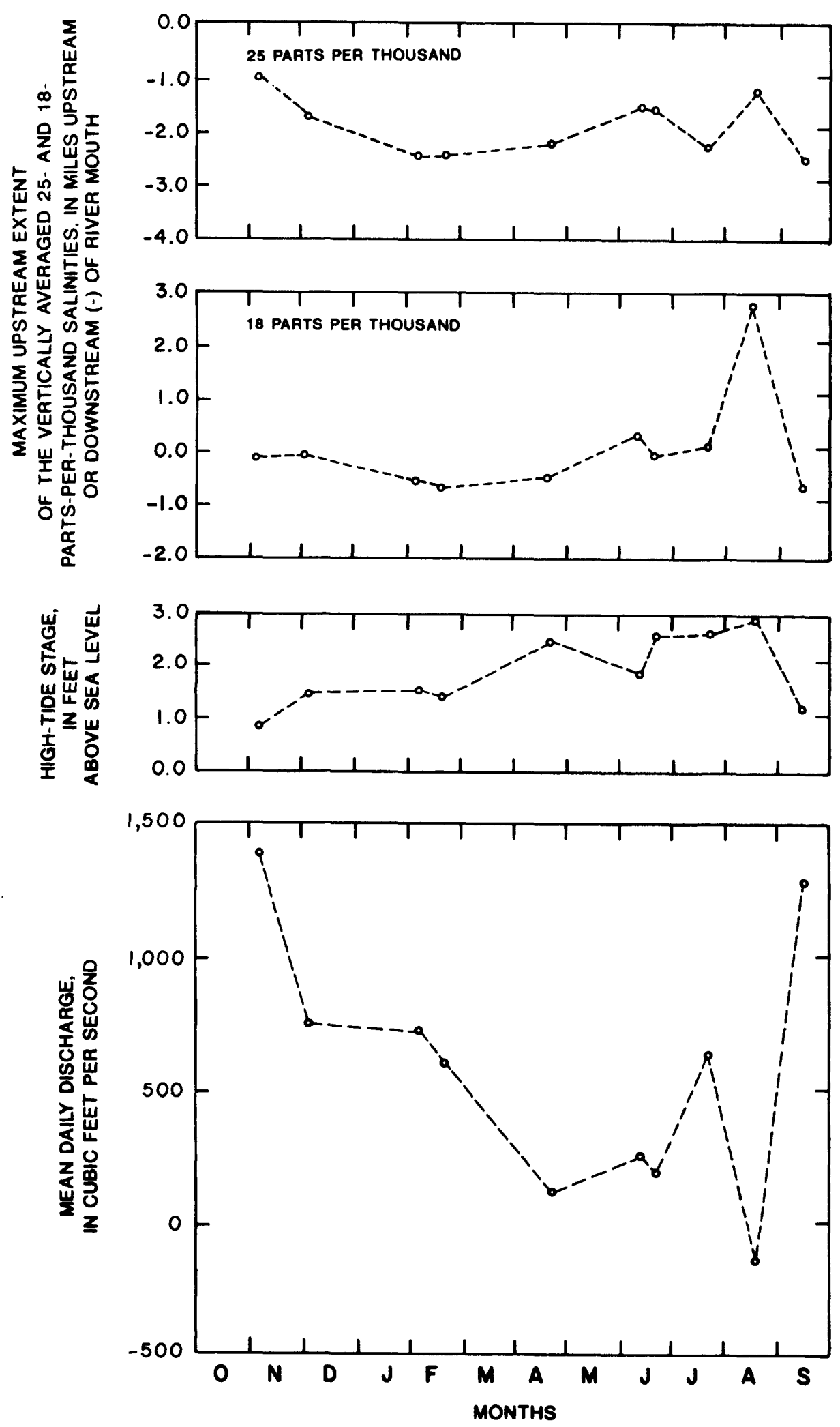

Figure 20.-Comparison between maximum upstream extent of the vertically averaged 25- and 18-parts-per-thousand salinities in the Crystal River Estuary and daily mean discharge and high-tide stage of Crystal River, October 1984 through September 1985. 


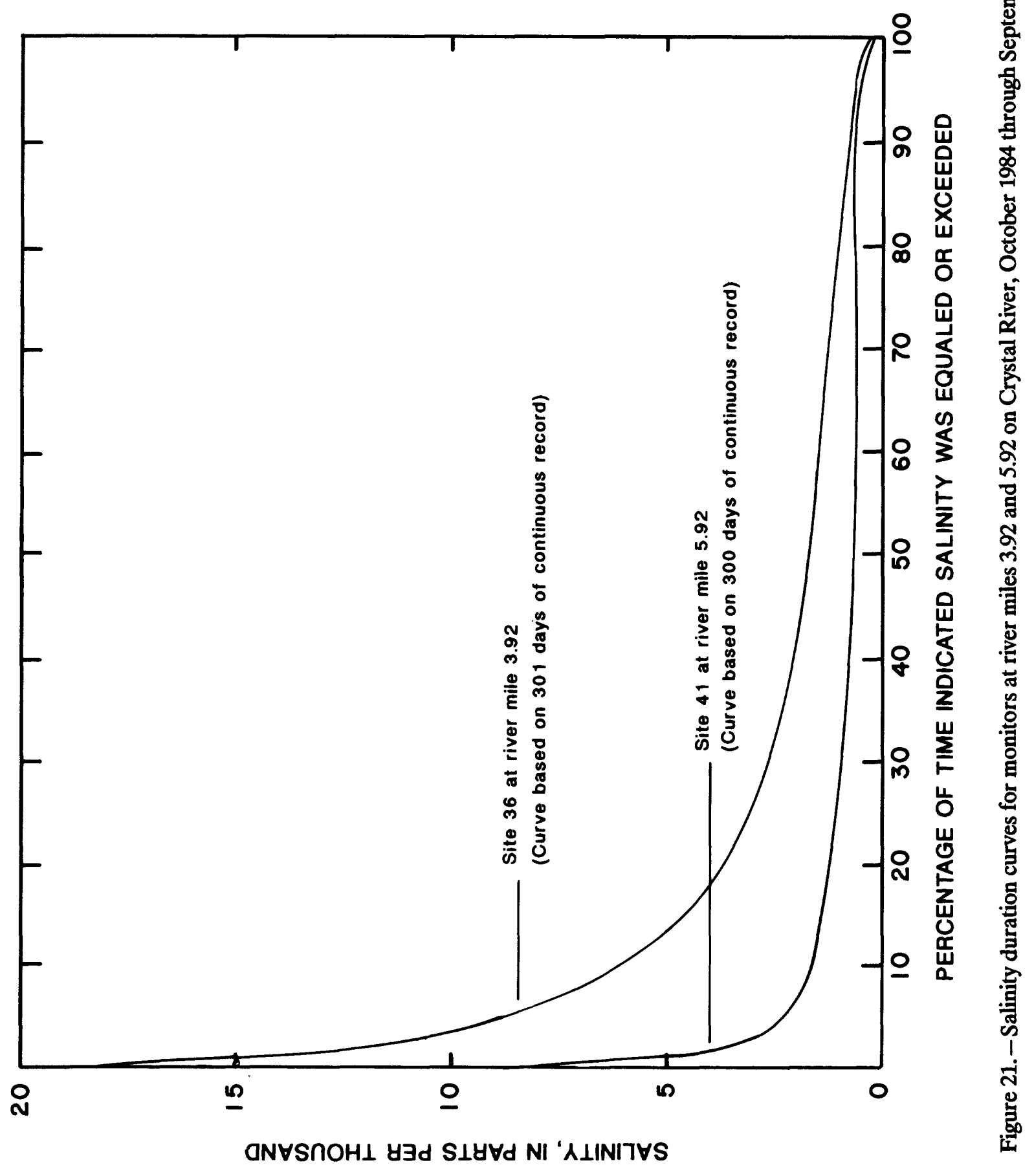


The lower Withlacoochee River is tidally affected along its entire length. Water levels in the river vary between 2 feet below and 4 feet above sea level, and the level is affected by tides and manipulation of flow through the bypass channel. The mean water surface slopes from about 0.5 to 1.5 feet above sea level in the vicinity of the bypass channel to about 0.1 to 1.0 foot above sea level at the river mouth. Since the opening of the bypass channel, a slight increase in the range of tidal elevation has occurred and is probably the result of shortening the lower (tidally affected) reach of the river (Bush, 1973).

The average discharge of the lower Withlacoochee River, measured at the bypass channel control structure between 1970 and 1984, is 1,140 $\mathrm{ft}^{3} / \mathrm{s}$. Daily mean discharge ranged from a maximum of $1,800 \mathrm{ft}^{3} / \mathrm{s}$ on June 19,1982 , to a minimum of $53 \mathrm{ft}^{3} / \mathrm{s}$ on October 11, 1972. Minimum recorded discharges are due to reservoir manipulations and do not represent natural low flows to the lower river. Prior to construction of the barge-canal complex, average daily discharge into the lower Withlacoochee River was 1,900 $\mathrm{ft}^{3} / \mathrm{s}$ for the period 1931 through 1969 (Bush, 1973). Because the approximate capacity of the bypass channel with a high backwater stage elevation is about $1,540 \mathrm{ft}^{3} / \mathrm{s}$, seasonal high discharge to the lower section of the river no longer occurs. The excess passes through the barge canal.

The monthly mean flow of the Withlacoochee River during the study period was compared with minimum, average, and maximum monthly discharge for the 14-year period of record, 1970-83 (fig. 22). The graph shows that streamflow for the majority of the study period (1984-85) was well below normal. Monthly flows were above average during October and November 1984 and August 1985 but were below average during the remaining months. During April and May, flows dropped below the previously recorded monthly minimum values. Flow-duration curves of daily discharge for the study period and 1970-83 are shown in figure 23.

The magnitude and frequency of estimated annual low flow of the Withlacoochee River are shown in table 8. The table shows that on the average, once every 2 years, the 90 -day average daily discharge will be less than $830 \mathrm{ft}^{3} / \mathrm{s}$. Average daily discharge for a 90 -day period will decline to $400 \mathrm{ft}^{3} / \mathrm{s}$ on the average of once every 20 years.

The chemical characteristics of water discharging to the lower Withlacoochee River from Lake Rousseau are summarized in table 9. The water is low in mineral content and is a calcium bicarbonate type with calcium the major constituent, which reflects the inflow of water from the Upper Floridan aquifer.

Longitudinal salinity profiles in the Withlacoochee River, measured under various streamflow and high-tide stages, are shown in figure 24. Daily discharges shown are for the day prior to the sampling day. The tide stage is the high-tide stage recorded at the river mouth. The profiles show salinity gradients becoming steeper with increasing distance upstream from the river mouth. Near the upstream extent of the saltwater intrusion, saltwater is found only in the bottom few feet. As in the Weeki Wachee River, lines of equal salinity are compressed near the salt front, indicating a narrow transition zone between gulf and river waters.

To examine the extent of vertical salinity stratification, ratios of top-to-bottom salinities were plotted for selected high-tide salinity measurements (fig. 25). Lower values indicate a more stratified vertical at the sampling site. The graphs show that vertical salinity stratification generally increases upstream to the end of the salt-front toe. The ratio of top-to-bottom salinity ranges from about 0.9 near the river mouth to about 0.1 near the toe of the salt front.

The range of salinity location at high tide in the Withlacoochee River Estuary varied and decreased upstream. As in the Weeki Wachee River Estuary, the upstream extent of lower concentration salinities appears to be less sensitive to changes in flow and tide stage than those of higher concentration salinities. The range in observed maximum upstream extent of selected salinities during the period of study is listed below:

\begin{tabular}{cccc}
\hline $\begin{array}{c}\text { Salinity, } \\
\text { in parts per } \\
\text { thousand }\end{array}$ & \multicolumn{3}{c}{$\begin{array}{c}\text { Maximum upstream extent of salinity, } \\
\text { in miles upstream or downstream }(-) \text { of the river mouth }\end{array}$} \\
\cline { 2 - 4 } Minimum & Maximum & Range \\
\hline 0.5 & 1.3 & 4.4 & 2.2 \\
5.0 & 1.8 & 4.1 & 2.3 \\
10.0 & .0 & 3.5 & 3.5 \\
15.0 & -1.9 & 2.4 & 4.3 \\
18.0 & -3.8 & 1.4 & 5.2 \\
20.0 & -4.8 & .6 & 5.4 \\
\hline
\end{tabular}




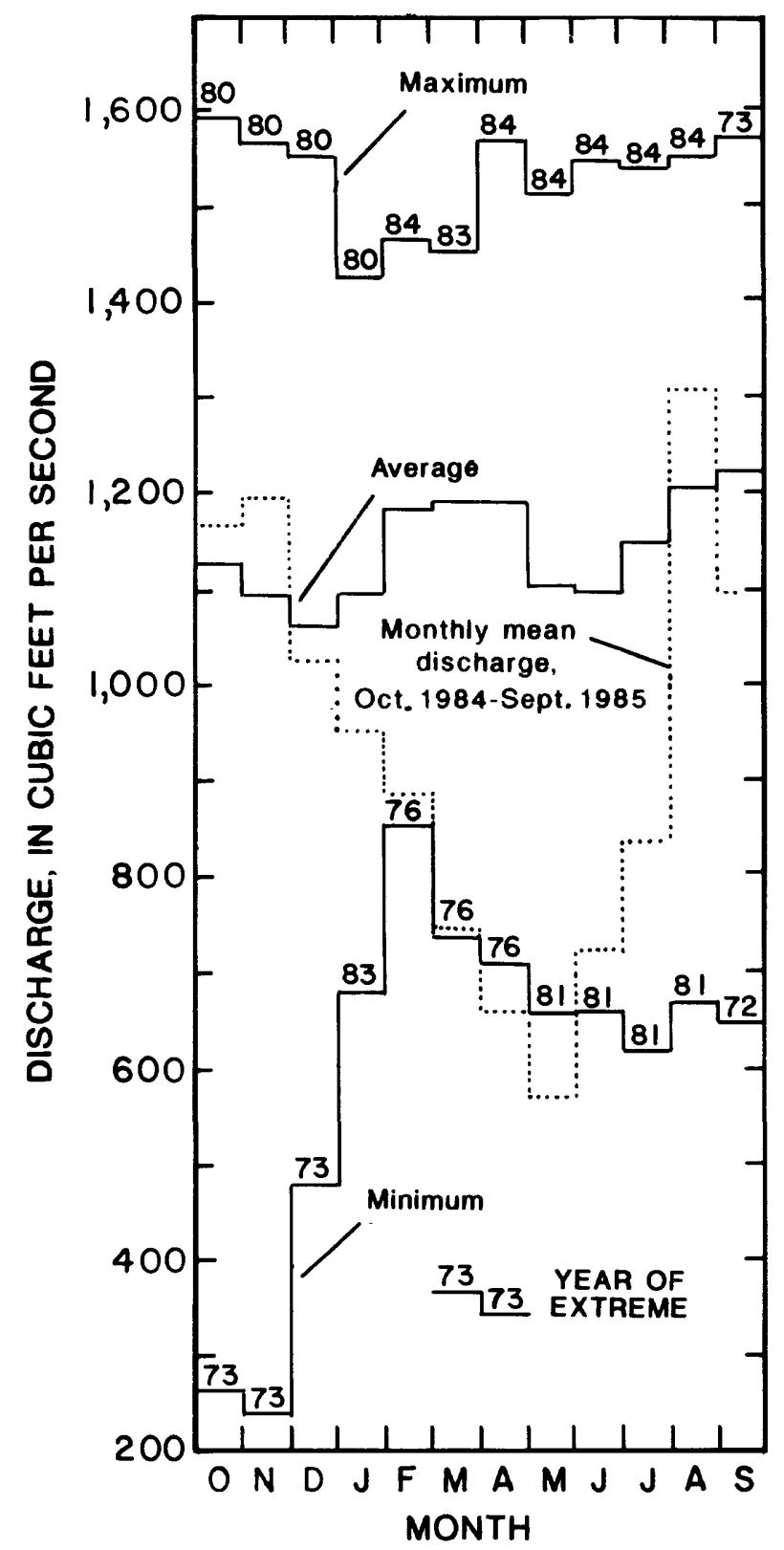

Figure 22. - Average, minimum, and maximum mean monthly discharges, 1970 through 1984 , and monthly mean discharges, October 1984 through September 1985, of the Withlacoochee River at the bypass channel.

The 20-ppt salinity had a range in location that was more than twice as large as the range in location of the 0.5 -ppt salinity.

The change in salinity along the Withlacoochee River Estuary was found to be highly variable. Variations in surface and bottom longitudinal salinities are shown in figures 26 and 27. The graphs show that salinities in surface and bottom waters decreased upstream with the longitudinal gradients at the upstream end being steeper at the surface than at the bottom. Longitudinal salinity gradients in surface and bottom waters are flat from the gulf to about 1 mile inside the river mouth. Upstream of river mile 1.0, salinity gradients steepen in both surface and bottom waters. Observed salinities at high tide at the bottom ranged from 20 to $31 \mathrm{ppt} 4.8$ miles offshore of the river mouth, from 9.9 to 22 ppt at the river mouth, from 5.6 to $19 \mathrm{ppt}$ at river mile 1.1, and from 0.3 to $8.6 \mathrm{ppt}$ at river mile 3.8 . 


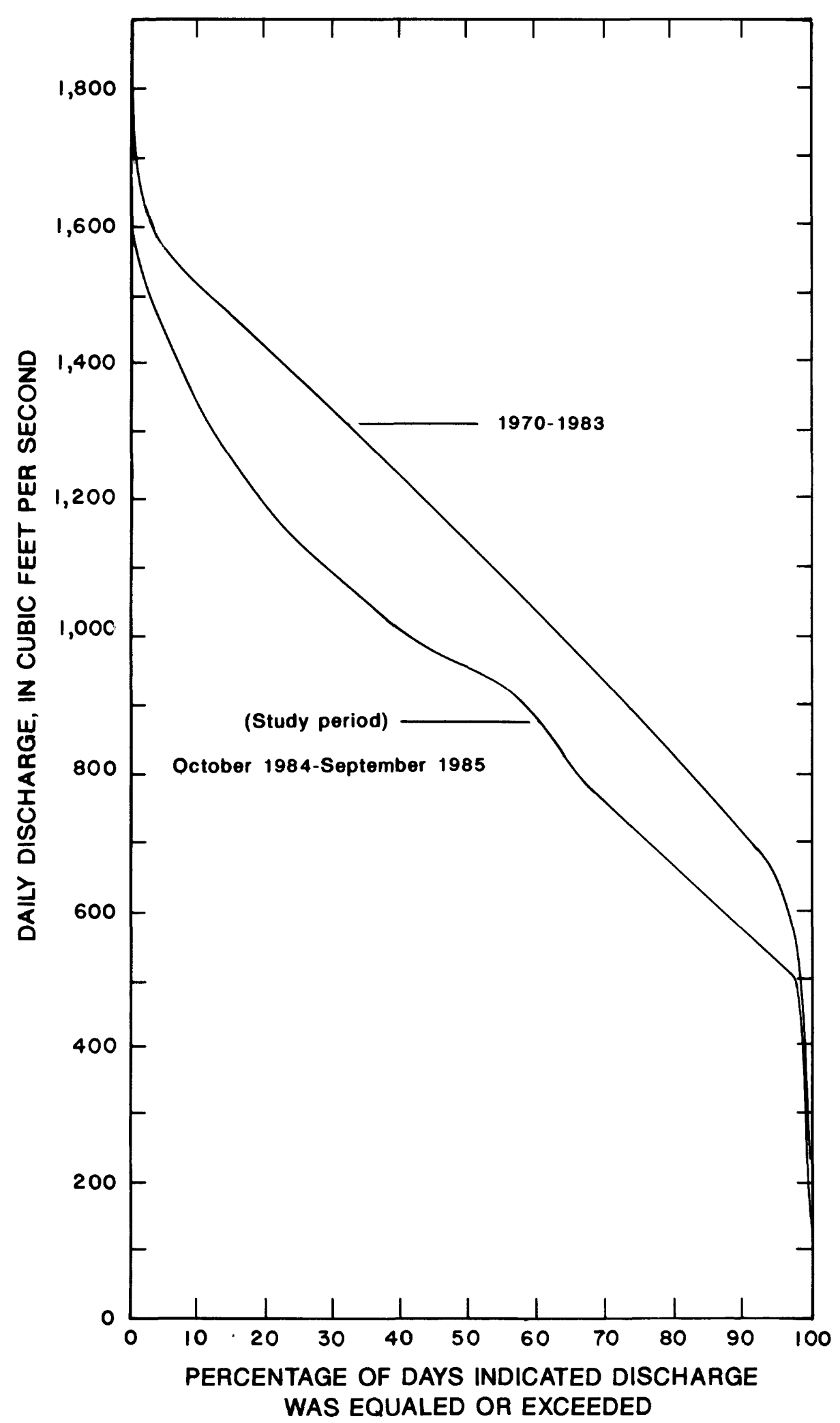

Figure 23. - Duration curves of daily mean discharge for the Withlacoochee River at the bypass channel for 1970 through 1983 and October 1984 through September 1985. 
Table 8. - Low-flow frequencies of Withlacoochee River bypass channel near Inglis, October 1970 to September 1981

[From Hammett, 1985]

\begin{tabular}{ccccc}
\hline $\begin{array}{c}\text { Period of } \\
\text { consecutive } \\
\text { days }\end{array}$ & \multicolumn{5}{c}{$\begin{array}{c}\text { Lowest average discharge, in cubic feet per second, for } \\
\text { indicated recurrence interval, in years }\end{array}$} \\
\cline { 2 - 5 } & 2 & 5 & 10 & 20 \\
\hline 1 & 600 & 330 & 190 & 100 \\
3 & 630 & 350 & 200 & 110 \\
7 & 670 & 400 & 250 & 150 \\
14 & 700 & 480 & 340 & 240 \\
30 & 760 & 540 & 400 & 290 \\
60 & 820 & 570 & 420 & 310 \\
90 & 830 & 620 & 490 & 400 \\
120 & 850 & 680 & 590 & 520 \\
183 & 930 & 800 & 730 & 680 \\
\hline
\end{tabular}

Table 9. - Chemical analysis of water from Lake Rousseau

[Concentrations are in milligrams per liter unless otherwise indicated. $\mu \mathrm{g} / \mathrm{L}$, micrograms per liter, $\mu \mathrm{S} / \mathrm{cm}$, microsiemens per centimeter. Sampling site L-2 is located about 5.5 miles above Inglis Dam. From German, 1978]

\begin{tabular}{|c|c|c|c|}
\hline \multirow[t]{2}{*}{ Constituent } & \multicolumn{2}{|c|}{ Concentration } & \multirow{2}{*}{$\begin{array}{c}\text { Number } \\
\text { of } \\
\text { samples }\end{array}$} \\
\hline & Minimum & Maximum & \\
\hline Silica $\left(\mathrm{SiO}_{2}\right)$ & 5.4 & 7.3 & 2 \\
\hline Iron, total $(\mu \mathrm{g} / \mathrm{L}$ as $\mathrm{Fe})$ & 20 & 100 & 2 \\
\hline Calcium, dissolved (Ca) & 40 & 46 & 7 \\
\hline Magnesium, dissolved (Mg) & 3.7 & 5.3 & 7 \\
\hline Sodium, dissolved (Na) & 3.4 & 3.5 & 2 \\
\hline Potassium, dissolved (K) & .1 & .2 & 2 \\
\hline Sulfate, dissolved $\left(\mathrm{SO}_{4}\right)$ & 17 & 21 & 2 \\
\hline Chloride, dissolved (Cl) & 3.2 & 7.8 & 17 \\
\hline Fluoride, dissolved (F) & .2 & .3 & 2 \\
\hline Nitrogen, total (N) & .26 & .71 & 20 \\
\hline Phosphorus, total (P) & .02 & .06 & 21 \\
\hline Dissolved solids & 154 & 169 & 2 \\
\hline Hardness (as $\mathrm{CaCO}_{3}$ ) & 120 & 140 & 17 \\
\hline Hardness, noncarbonate (as $\mathrm{CaCO}_{3}$ ) & 13 & 42 & 12 \\
\hline Bicarbonate (as $\mathrm{CaCO}_{3}$ ) & 120 & 140 & 12 \\
\hline Carbonate & 0 & 0 & 18 \\
\hline Specific conductance $(\mu \mathrm{S} / \mathrm{cm})$ & 237 & 295 & 20 \\
\hline
\end{tabular}

The observed maximum upstream extent of the vertically averaged 0.5 -ppt salinity was at river mile 4.36 at a discharge of $511 \mathrm{ft}^{3} / \mathrm{s}$ and a hightide stage of 3.21 feet. At flows of less than 1,000 $\mathrm{ft}^{3} / \mathrm{s}$ and high-tide stages above 1.9 feet, the vertically averaged 0.5 -ppt salinity was found upstream of river mile 2.9. At flows of more than $1,000 \mathrm{ft}^{3} / \mathrm{s}$ and tide stages of less than 2.7 feet, the upstream extent of the vertically averaged 0.5 -ppt salinity did not reach river mile 2.7 and was found downstream of river mile 1.29 at a streamflow of $1,160 \mathrm{ft}^{3} / \mathrm{s}$ and a high-tide stage of 1.85 feet. 


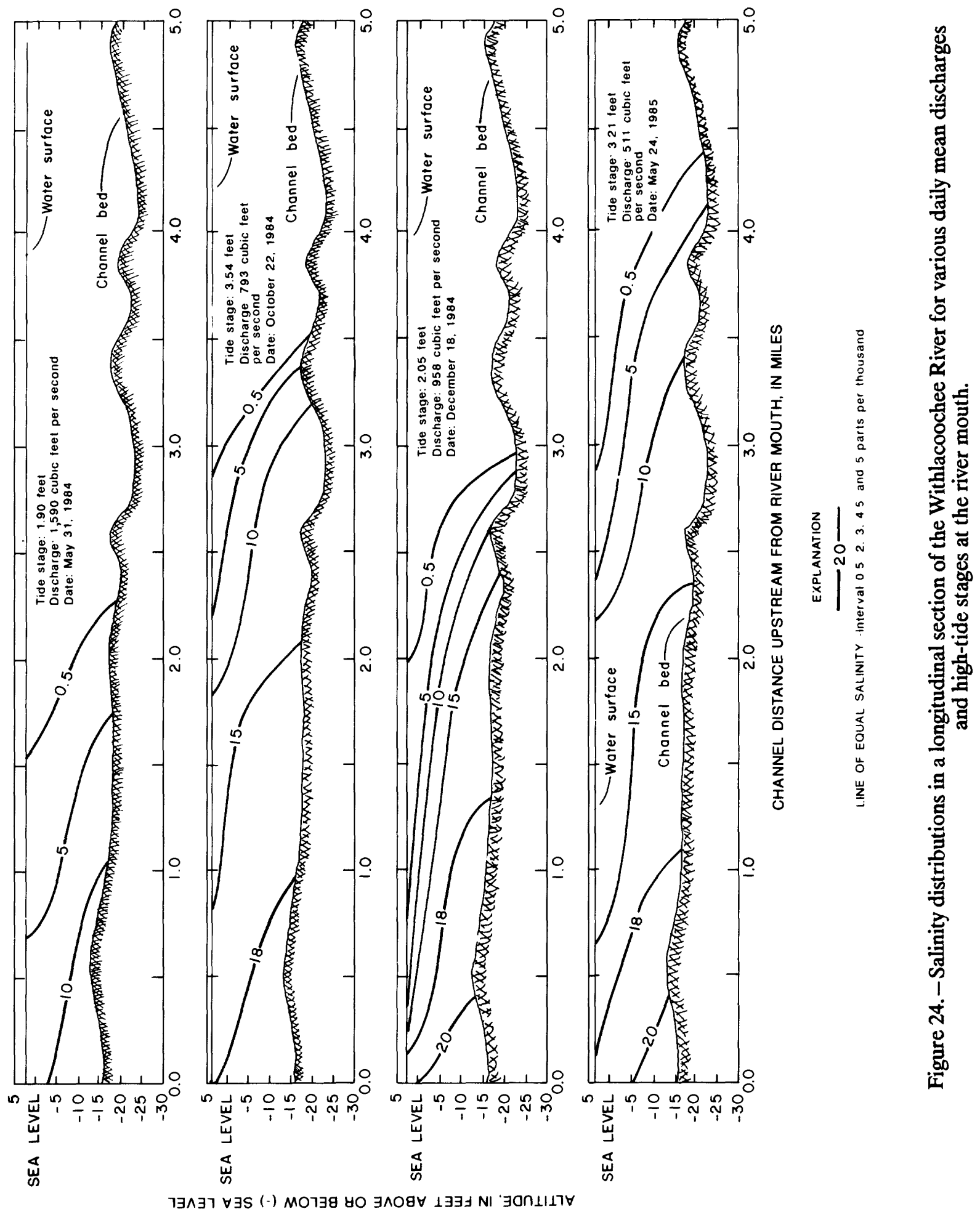




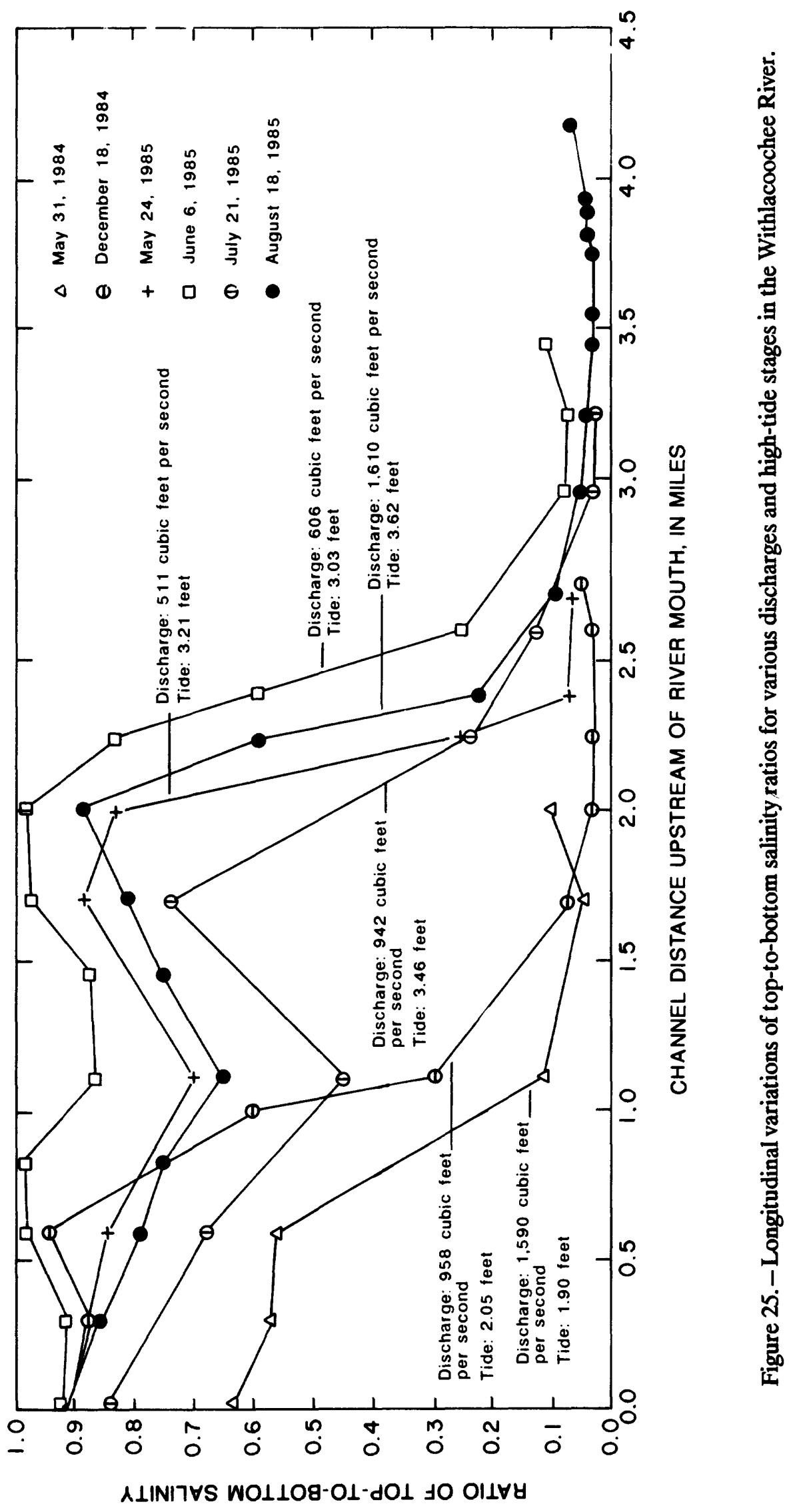



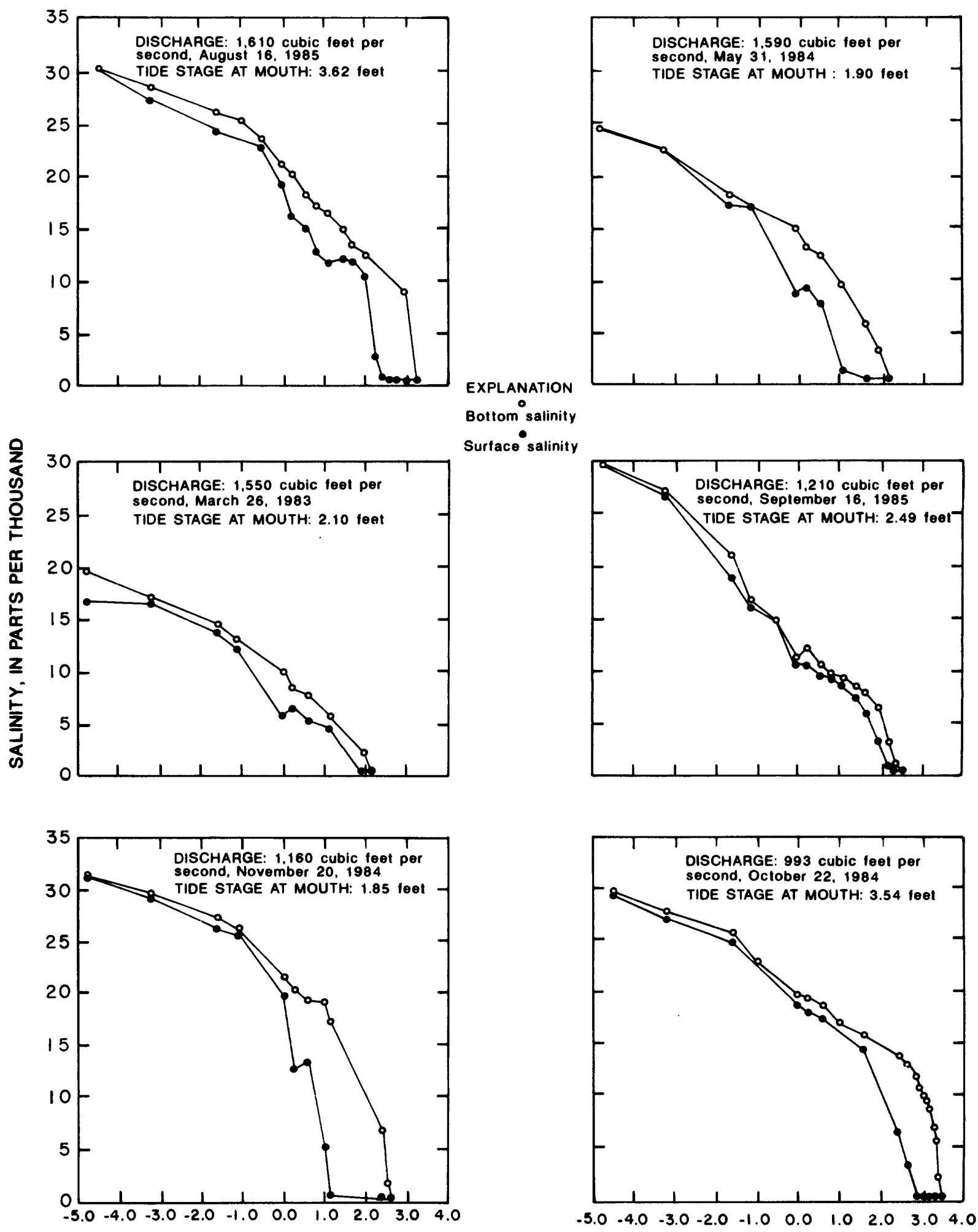

CHANNEL DISTANCE UPSTREAM OR DOWNSTREAM (-) OF RIVER MOUTH, IN MILES

Figure 26. - Longitudinal variations of surface and bottom salinities at high-tide stages in the Withlacoochee River Estuary for discharges of 993 to 1,610 cubic feet per second. 

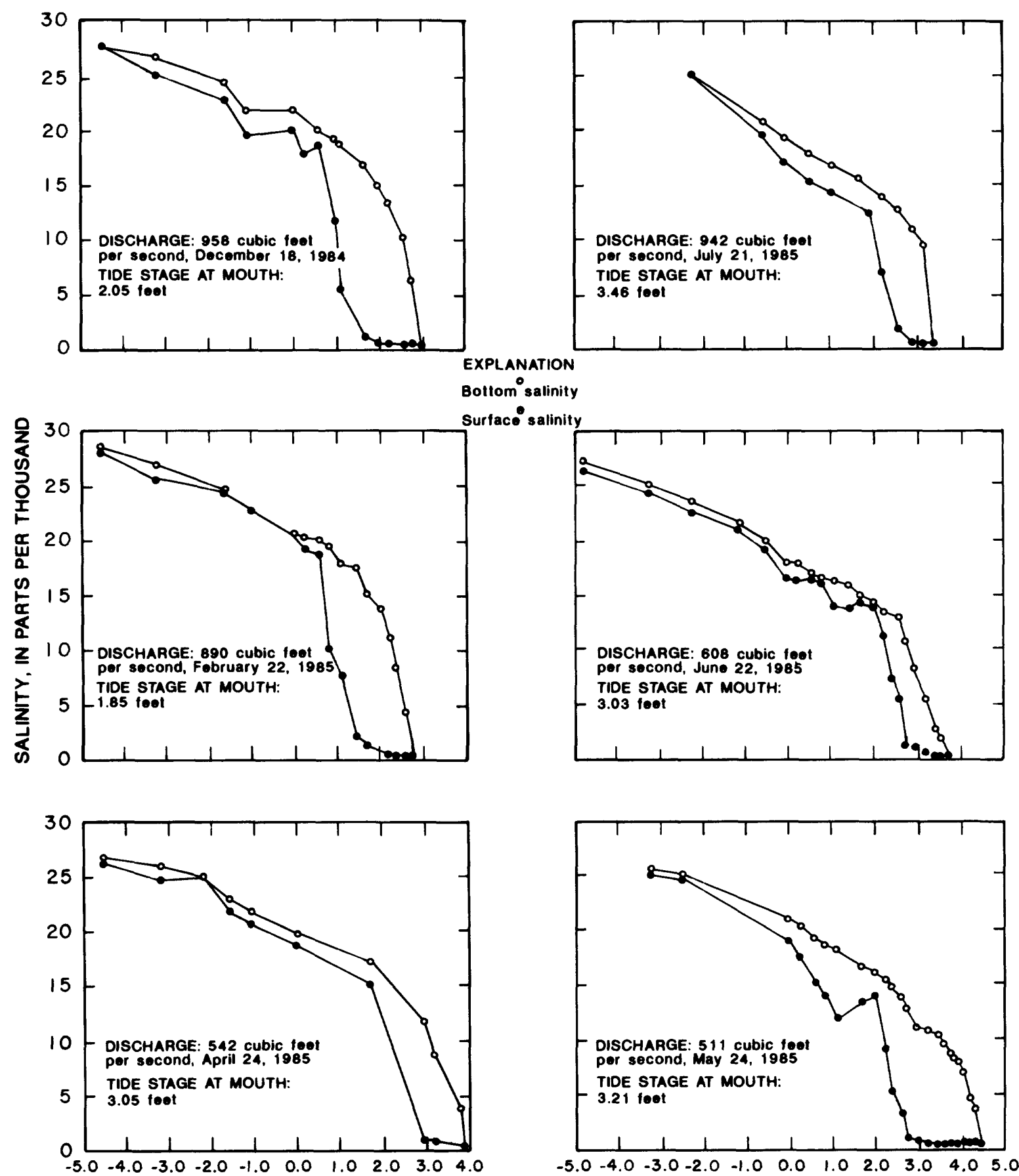

CHANNEL DISTANCE UPSTREAM OR DOWNSTREAM (-) OF RIVER MOUTH, IN MILES

Figure 27. - Longitudinal variations of surface and bottom salinities at high-tide stages in the Withlacoochee River Estuary for discharges of 511 to 958 cubic feet per second. 
A consistent correlation was not observed between streamflow and salinity variations in the gulf. A comparison of month-to-month salinity in the gulf at site 49 (fig. 7) and discharge of the Withlacoochee River at the bypass channel (fig. 7, site 77) and Inglis Dam for the period April 1983 through September 1985 is shown in figure 28. As in the Weeki Wachee River and Crystal River Estuaries, a simple relation is not apparent, and at times, contradictory trends occur in the data.

Salinity duration curves for the continuousrecord sites at river miles $0.00,1.70$, and 2.96 are

\section{EFFECTS OF RIVER DISCHARGE AND HIGH-TIDE STAGE ON SALINITY INTRUSION}

\section{Weeki Wachee River}

Multiple linear-regression analysis was used to relate the observed maximum upstream extent of the vertically averaged 5- and 0.5 -ppt salinities to calculated daily mean discharge at river mile 6.8 (fig. 5, site 18) and observed high-tide stage at river mile 0.05 (fig. 5 , site 5). Observed values used for development of regression equations are as follows:

\begin{tabular}{ccccc}
\hline & \multirow{2}{*}{$\begin{array}{c}\text { Discharge } \\
\left(\mathrm{ft}^{3} / \mathrm{s}\right)\end{array}$} & $\begin{array}{c}\text { High } \\
\text { tide } \\
\text { (feet) }\end{array}$ & $\begin{array}{c}\text { Maximum upstream extent of salinity, in miles upstream or } \\
\text { downstream }(-) \text { of the river mouth }\end{array}$ \\
\cline { 4 - 6 } & & 2.05 & $\begin{array}{c}\text { 5 parts } \\
\text { per thousand }\end{array}$ & $\begin{array}{c}\text { 0.5 part } \\
\text { per thousand }\end{array}$ \\
\hline 1 & 151 & 2.53 & 1.26 & 1.43 \\
2 & 152 & 3.09 & 1.54 & 1.62 \\
3 & 152 & 1.74 & 1.51 \\
4 & 162 & 1.13 & 1.44 & 1.31 \\
5 & 182 & 1.13 & 1.01 & 1.51 \\
6 & 189 & 2.76 & 1.43 & 1.25 \\
7 & 199 & 2.54 & 1.16 & 1.39 \\
8 & 209 & 2.33 & .54 & 1.37 \\
9 & 211 & 2.35 & .96 & 1.42 \\
10 & 225 & 1.46 & 1.00 & 1.45 \\
11 & 229 & 2.20 & 1.30 & \\
12 & 244 & 2.74 & -.04 & \\
\hline
\end{tabular}

shown in figure 29. From October 1984 through September 1985 , salinity greater than $0.5 \mathrm{ppt}$ was present 27 percent of the time at river mile 2.96, 72 percent of the time at river mile 1.70 , and about 99 percent of the time at river mile 0.00 from October 1984 through September 1985. The salinity that was equaled or exceeded 10 percent of the time at the mouth $(19.2 \mathrm{ppt})$ was about two times (8.6 ppt) and nine times ( $2.1 \mathrm{ppt})$ as great as the salinity at the middle and upper monitors, respectively.
Daily discharge data used in the regression analysis ranged from 151 to $244 \mathrm{ft}^{3} / \mathrm{s}$, which were exceeded 80 and 1 percent of the days, respectively, for 1975-84 and 94 and 0 percent of the days, respectively, for October 1984 through September 1985. High-tide stages ranged from 1.13 to 3.09 feet, which were exceeded 97 and 5 percent of the days, respectively, for October 1984 through September 1985.

Various combinations of the data set were evaluated to develop the best equations for predicting the maximum upstream location of the vertically averaged 5 - and 0.5 -ppt salinities.

\begin{tabular}{|c|c|c|c|c|c|c|c|c|}
\hline \multirow{2}{*}{$\begin{array}{l}\text { Equa- } \\
\text { tion } \\
\text { No. }\end{array}$} & \multirow[b]{2}{*}{$\begin{array}{l}\text { Salinity } \\
\text { (ppt) }\end{array}$} & \multirow[b]{2}{*}{$\begin{array}{c}\text { Discharge } \\
\left(\mathrm{ft}^{3} / \mathrm{s}\right)\end{array}$} & \multirow[b]{2}{*}{$\mathbf{N}$} & \multirow[b]{2}{*}{ Predictive equation } & \multicolumn{4}{|c|}{ Statistics } \\
\hline & & & & & $\mathbf{R}^{2}$ & RMSE & $\mathbf{Q}$ & HT \\
\hline 2 & 5.0 & $151-244$ & 12 & $L=0.035(H T)-0.011(Q)+3.10$ & 0.54 & 0.36 & 0.0106 & 0.8663 \\
\hline 3 & & $151-199$ & 7 & $L=0.284(\mathrm{HT})-0.006(\mathrm{Q})+1.73$ & .88 & .10 & .0496 & .0141 \\
\hline 4 & 0.5 & $151-244$ & 12 & $L=0.176(H T)-0.003(Q)+1.56$ & .62 & 12 & 0417 & 0237 \\
\hline 5 & & $151-199$ & 7 & $L=0.212(H T)-0.005(Q)+1.85$ & .79 & .11 & .1000 & .0414 \\
\hline
\end{tabular}

where

L = location of the maximum upstream extent of the vertically averaged 5- and 0.5-ppt salinities, in miles upstream of the river mouth;

HT = high-tide stage, in feet above sea level;

$\mathrm{Q} \quad=$ calculated daily mean discharge, in cubic feet per second;

$\mathbf{R}^{2} \quad=$ square of the correlation coefficient;

RMSE = root mean square error, in \pm miles;

PR = probability that the regression coefficient of $Q$ or HT equals zero; and

$\mathbf{N}=$ number of observations. 


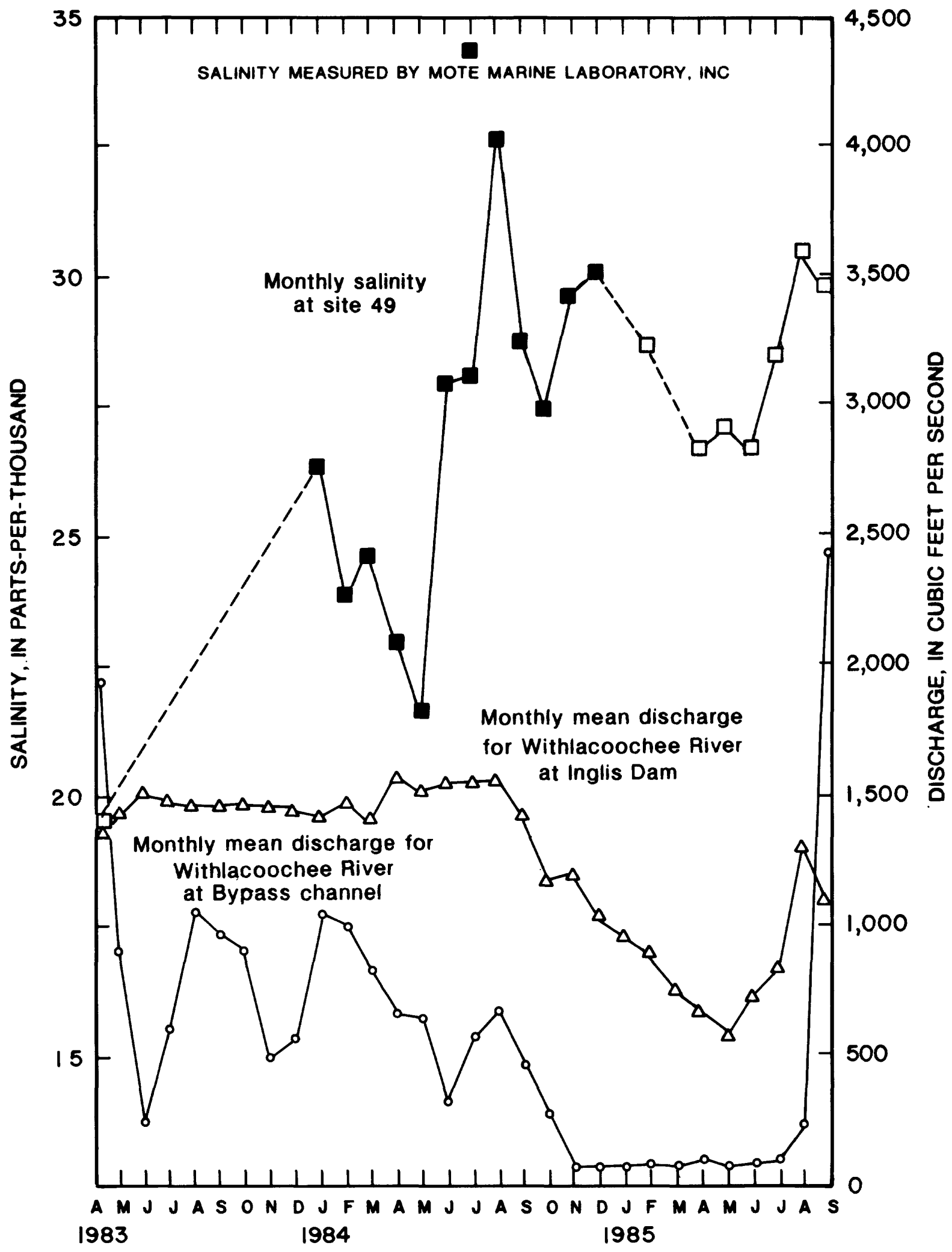

Figure 28. - Variation in monthly salinity in Gulf of Mexico at site 49 and monthly mean discharge of Withlacoochee River at the bypass channel and Withlacoochee River at Inglis Dam, April 1983 through September 1985. 


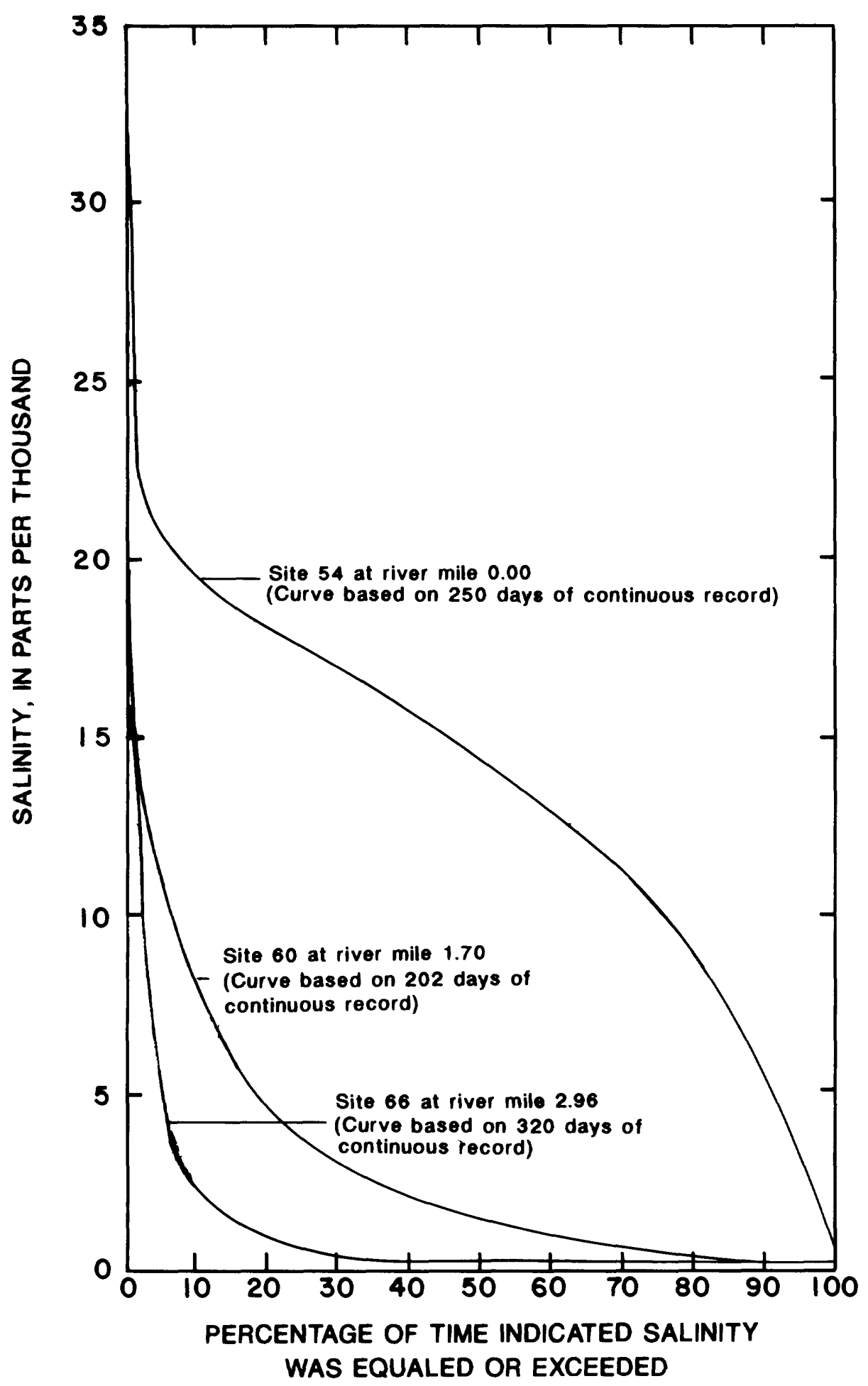

Figure 29. - Salinity duration curves for monitors at river miles 0.00 , 1.70 , and 2.96 on the Withlacoochee River, October 1984 through September 1985. 
The equations are based on different ranges of discharge. Equations 3 and 5 are for discharges less than $200 \mathrm{ft}^{3} / \mathrm{s}$ and equations 2 and 4 are for discharges less than $245 \mathrm{ft}^{3} / \mathrm{s}$.

For equations 2 and 4, discharge was determined to be more sensitive than tide stage in predicting the salinity location. A 25-percent reduction in discharge from 199 to $150 \mathrm{ft}^{3} / \mathrm{s}$ results in a 0.3-mile increase in the upstream location of the vertically averaged 5-ppt salinity (from river mile 1.16 to 1.46 ) and a 0.25 -mile increase in upstream location of the vertically averaged 0.5 -ppt salinity (from river mile 1.32 to 1.57). A 25-percent increase in tide stage (from 2.23 to 2.79 feet) results in a 0.16 -mile increase in the maximum upstream location of the vertically averaged 5-ppt salinity (from river mile 1.16 to 1.32) and a 0.12-mile increase in the maximum upstream location of the vertically averaged 0.5 -ppt salinity (from river mile 1.32 to 1.44 ). For equations 3 and 5, streamflow also was determined to be more sensitive than tide stage in predicting the upstream locations of the vertically averaged 5- and 0.5-ppt salinities.

The salinity locations upstream from Mud River (river mile 0.8 ) are generally better defined by equations 3 and 5 than by equations 2 and 4 . The salinity locations using all data include two observations downstream from Mud River where the relation is not as well defined. The data set also includes three observations upstream of Mud River for discharges above $200 \mathrm{ft}^{3} / \mathrm{s}$ where the relation also is not well defined.

Predictive equations describing the location of the daily maximum upstream extent of the vertically averaged 25 - and 18-ppt salinities were developed in a simple linear-regression analysis using the salinity locations as the dependent variable and recorded salinity at river mile 0.05 (fig. 5, site 5) as the independent variable (fig. 30). The relations show a good correlation; the $\mathrm{R}^{2}$ for the regression equations is 0.96 , and the RMSE's are 0.32 and 0.35 mile.

Distance duration curves for the vertically averaged 25-, 18-, 5-, and 0.5-ppt salinities (fig. 31) at higher high tide were computed for the period of record (October 1984 through September 1985). Equations 2 through 5 were used to compute the curves for the vertically averaged 0.5 - and 5-ppt salinities and the relation shown in figure $\mathbf{3 0}$ was used for the vertically averaged 18 - and 25 -ppt salinities. The curves show that the vertically averaged 0.5 -ppt salinity can be expected to be found between about 1 and 2 miles upstream of the river mouth; the vertically averaged 5-ppt salinity can be expected to be found between the river mouth and 2 miles upstream of the river mouth; the vertically averaged 18-ppt salinity goes no farther than about 1 mile upstream of the river mouth; and the vertically averaged $25-\mathrm{ppt}$ salinity can be expected to be found between 0 and 6 miles offshore. Locations and duration of the vertically averaged 5- and 0.5-ppt salinities in the Weeki Wachee River for October 1984 through September 1985 are shown in figure 32.

Because streamflow affects salinity, which, in turn, affects estuarine fauna and flora, withdrawals or reductions of flow, especially during low-flow periods, are of particular concern to ecologists and water managers. Therefore, equations 3 and 5 with higher high-tide stages of known duration (fig. 3) and various constant low-flow discharges were used to estimate the frequency of the upstream extent of the vertically averaged 0.5- and 5-ppt salinities (fig. 33). The curves of this type can be used to estimate the effects of reductions in river discharge. At a discharge of $199 \mathrm{ft}^{3} / \mathrm{s}$, the vertically averaged 5- and 0.5 -ppt salinities will be at or upstream of miles 1.18 and 1.31, respectively, about 50 percent of the days. At a discharge of $151 \mathrm{ft}^{3} / \mathrm{s}$, the vertically averaged 5- and 0.5-ppt salinities will be at or upstream of miles 1.47 and 1.57 , respectively, about 50 percent of the days. For discharges below $151 \mathrm{ft}^{3} / \mathrm{s}$, the validity of using equations 3 and 5 for estimating locations of the vertically averaged 5- and 0.5-ppt salinities is uncertain.

The flow of the Weeki Wachee River may be affected by either direct surface withdrawals from the river or by ground-water pumpage from the Upper Floridan aquifer. The effect of withdrawals made from the aquifer, however, would be less than if the withdrawal was made directly from the river or springs. To estimate the effect of ground-water development on spring flows that discharge to the rivers in coastal Citrus and Hernando Counties, a digital ground-water flow model was developed to approximate the steadystate ground-water flow system (Yobbi, 1989). The model was used to estimate the maximum effect on spring flow. Sixteen computer runs were made, one at a time, with a total pumpage of $40 \mathrm{Mgal} / \mathrm{d}\left(61.9 \mathrm{ft}^{3} / \mathrm{s}\right)$ during each run from a single well in the center of the grid block of the 


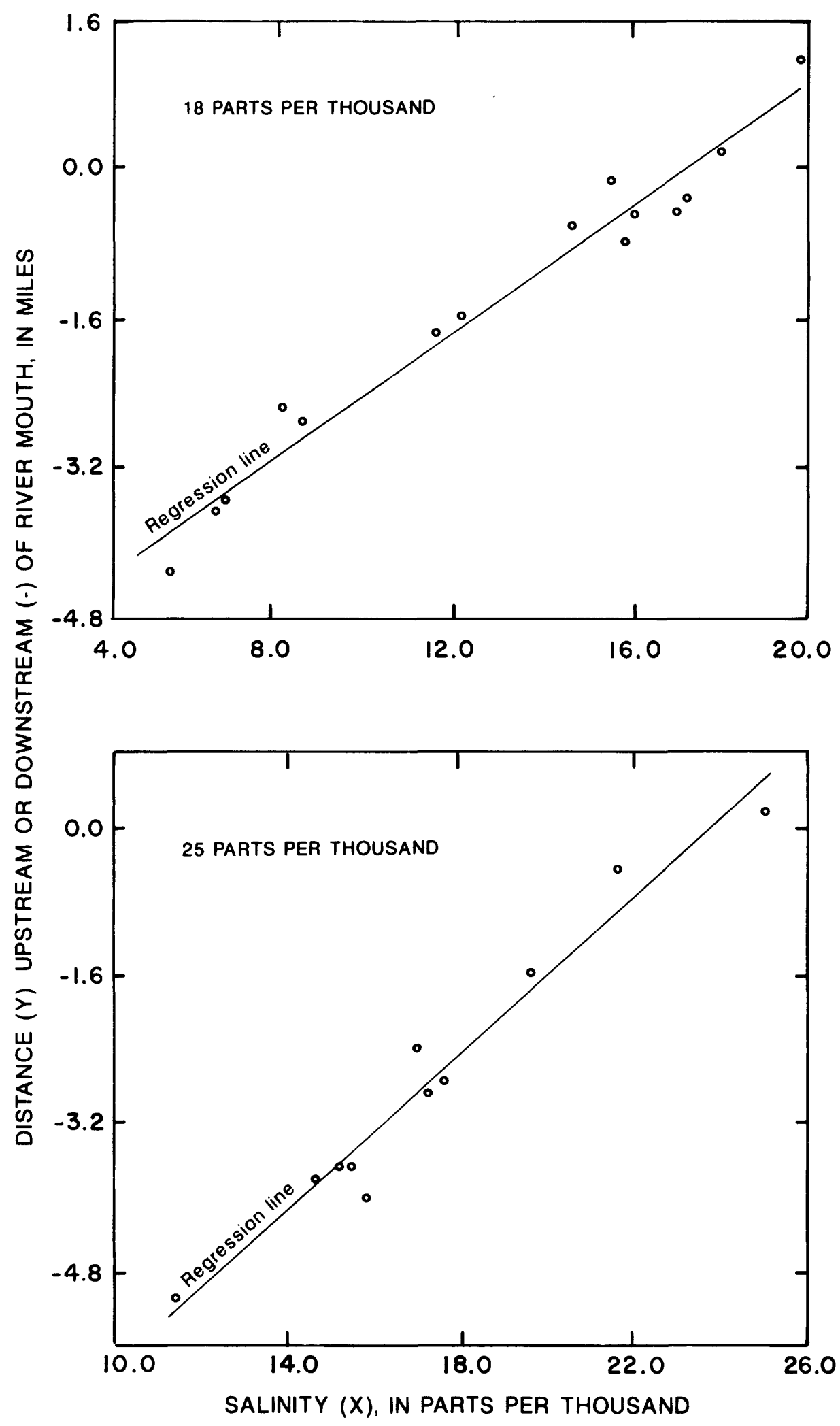

Figure 30. - Relation between salinity at river mile 0.05 and location of the maximum upstream extent of the vertically averaged 18- and 25-parts-per-thousand salinities in the Weeki Wachee River Estuary. 


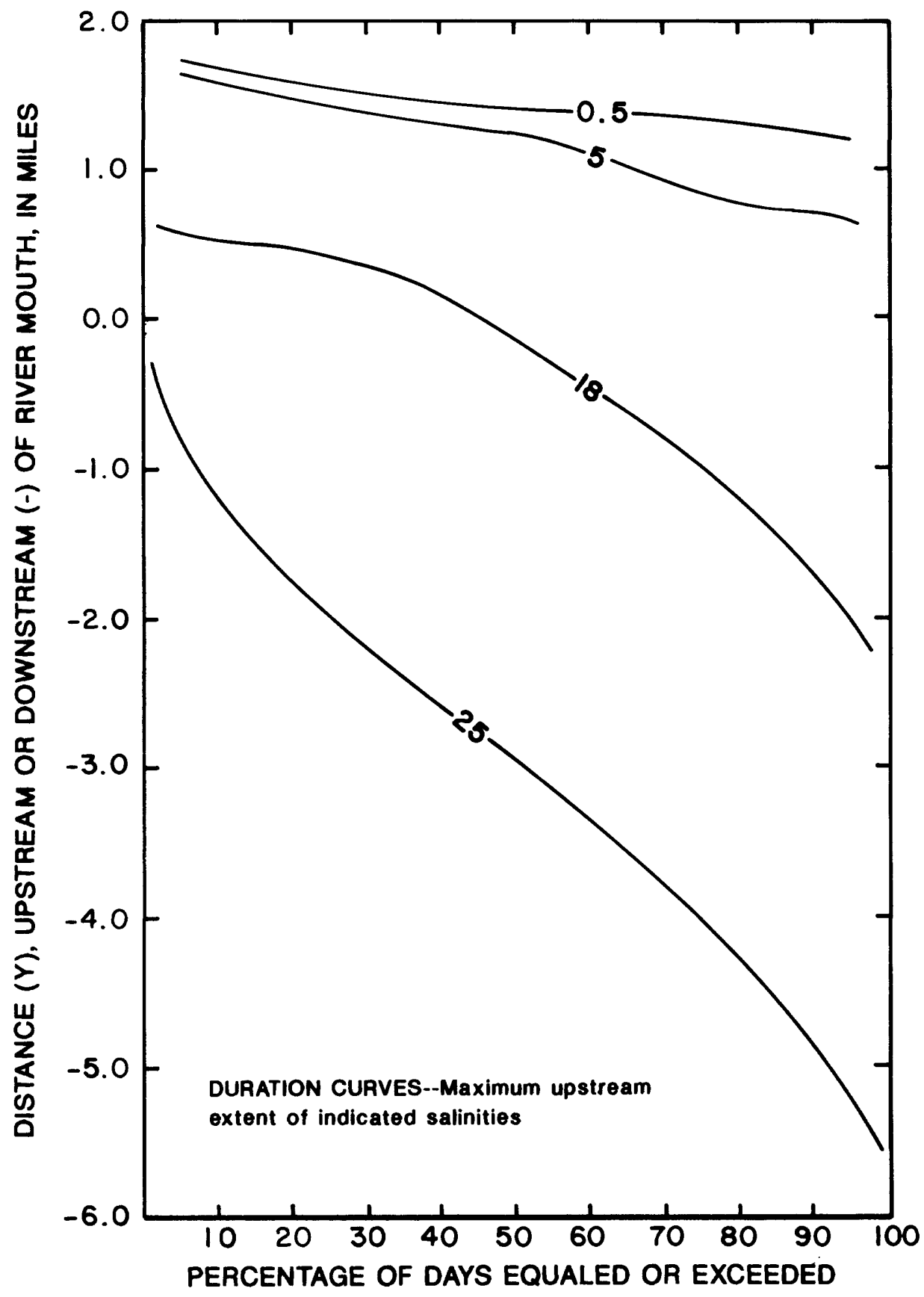

Figure 31.-Duration curves for computed locations of the daily maximum upstream extent of the vertically averaged $0.5-, 5-, 18-$, and 25-parts-per-thousand salinities in the Weeki Wachee River Estuary, October 1984 through September 1985. 

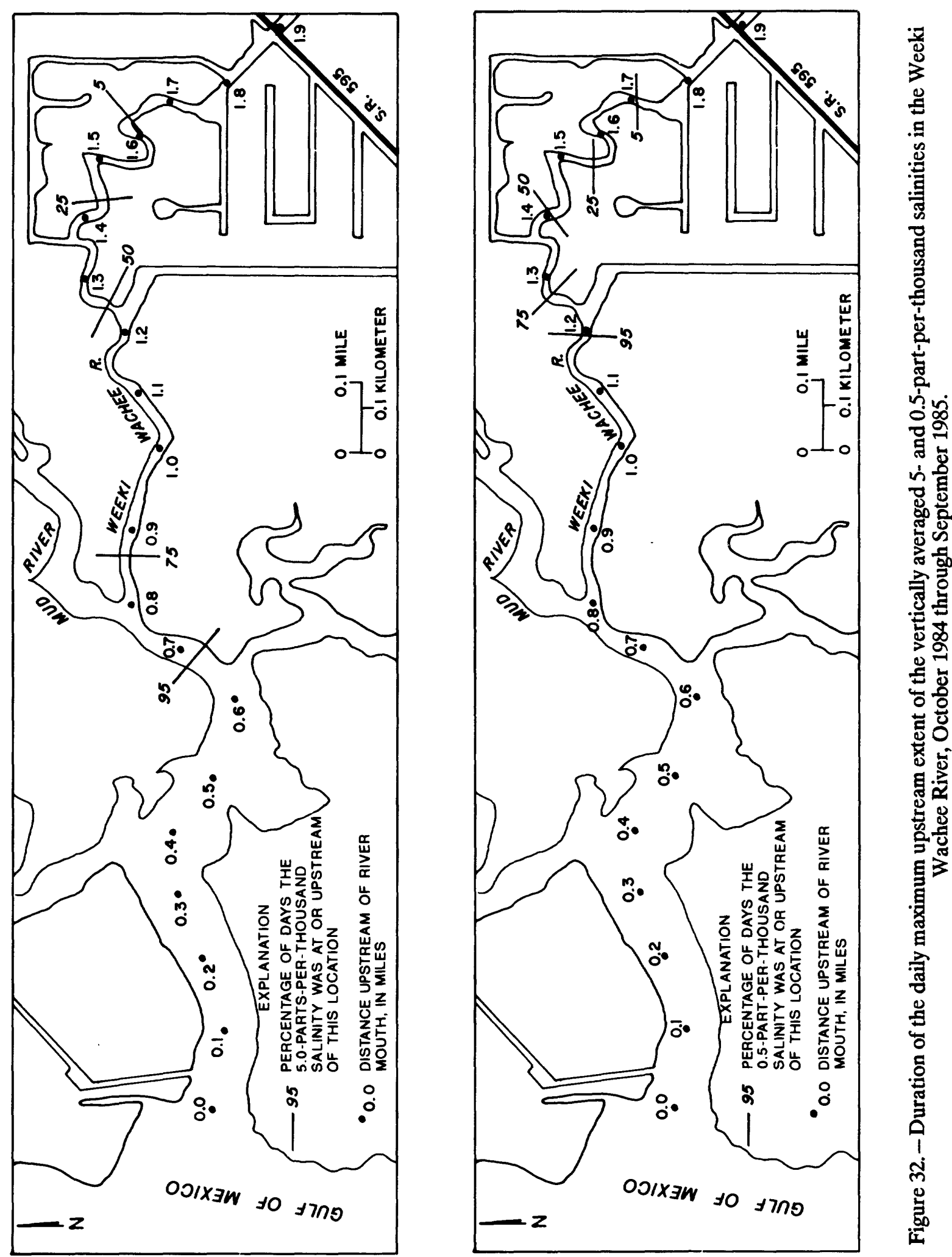


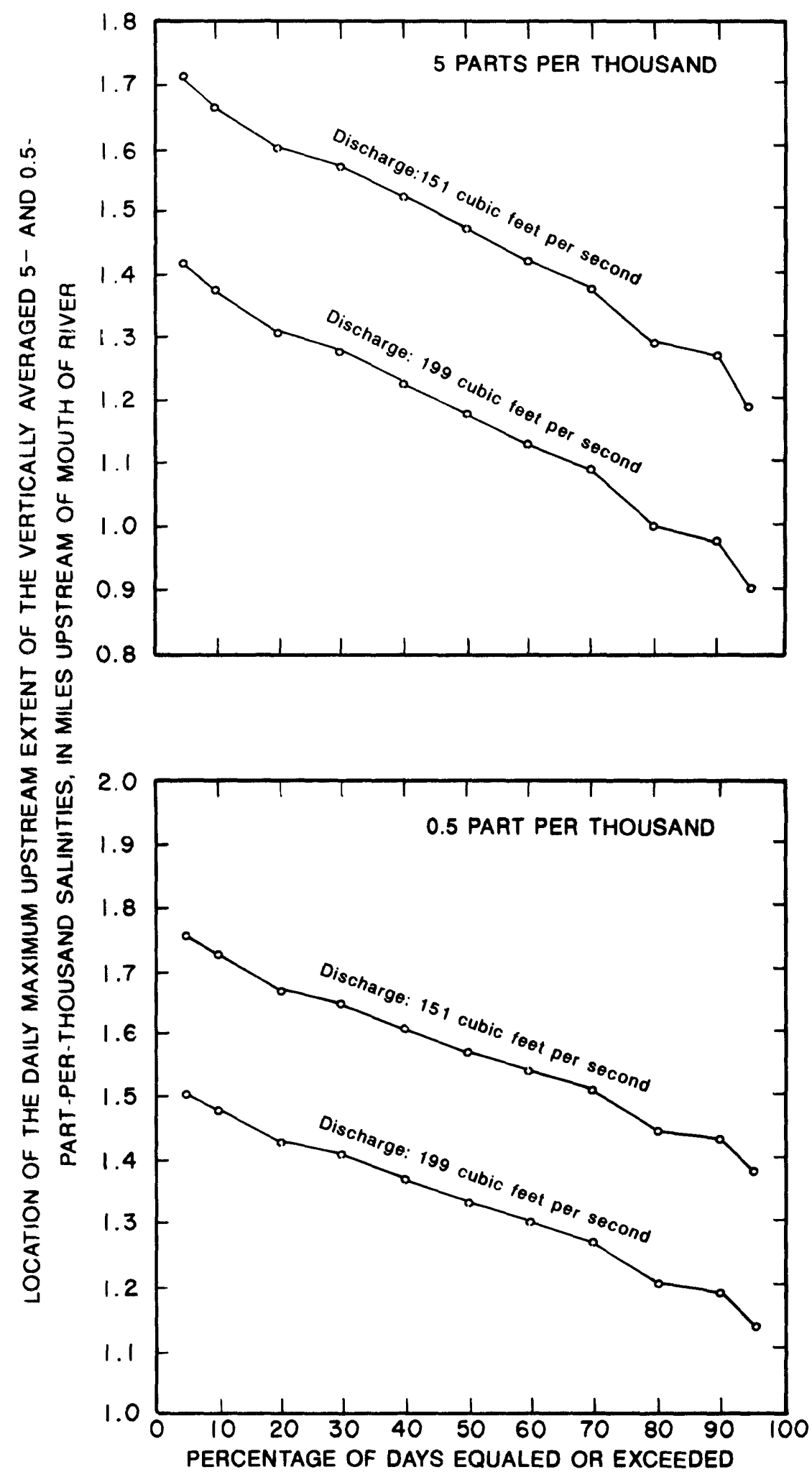

Figure 33. - Duration curves of the daily maximum upstream extent of the vertically averaged 5- and 0.5-part-perthousand salinities in the Weeki Wachee River for variable higher high tides and discharge. 
spring groups. A pumping rate of $40 \mathrm{Mgal} / \mathrm{d}$ was selected because it is generally the maximum permitted average daily pumpage from a well field within the Southwest Florida Water Management District (Fretwell, 1983). The springs considered and the results of the simulations are summarized in table 10. The impacts would be less if pumping were distributed over a wider area, as is the common practice in west-central Florida.

Table 10 shows that a $40-\mathrm{Mgal} / \mathrm{d}\left(61.9 \mathrm{ft}^{3} / \mathrm{s}\right)$ ground-water withdrawal from the aquifer within 2 miles of Weeki Wachee Springs would cause a $43-\mathrm{ft}^{3} / \mathrm{s}$ reduction in spring flow. To show the effect of a $43-\mathrm{ft}^{3} / \mathrm{s}$ reduction of discharge in the Weeki Wachee River, flow-duration data for the 25-percent interval $\left(199 \mathrm{ft}^{3} / \mathrm{s}\right)$ and a mean higher high-tide stage of 2.5 feet were used with equations 3 and 5 to estimate changes in daily maximum upstream extent of the vertically averaged 5- and 0.5-ppt salinities. Reducing discharge from 199 to $156 \mathrm{ft}^{3} / \mathrm{s}$ would result in an upstream movement of the vertically averaged 5-ppt salinity of about 0.26 mile (mile 1.24 to 1.50 ) and an upstream movement of the vertically averaged 0.5 -ppt salinity of 0.2 mile (mile 1.4 to 1.6). Although river discharge is reduced by 22 percent, the net change in upstream extent of saltwater intrusion is less than 0.3 mile.

The effect of reducing discharge on salinity intrusion for certain sections of the river also can be estimated by applying figure 33. A $43-\mathrm{ft}^{3} / \mathrm{s}$ reduction of flow, from 199 to $156 \mathrm{ft}^{3} / \mathrm{s}$, would increase the frequency of salinity intrusion (0.5-ppt salinity) at mile 1.5 from about 6 to 65 percent. This would allow salinity above $0.5 \mathrm{ppt}$ to reach this point of the river at high tide on an additional 215 days per year. Effects of other reductions in discharge at these and other river discharges and high-tide stages can be computed using equations 3 and 5 .

Table 10. - Simulated reduction of spring flow due to withdrawing 40 million gallons per day within 2 miles of springs

[ $\mathrm{ft}^{3} / \mathrm{s}$, cubic feet per second; Mgal/d, million gallons per day. Modified from Yobbi, 1989]

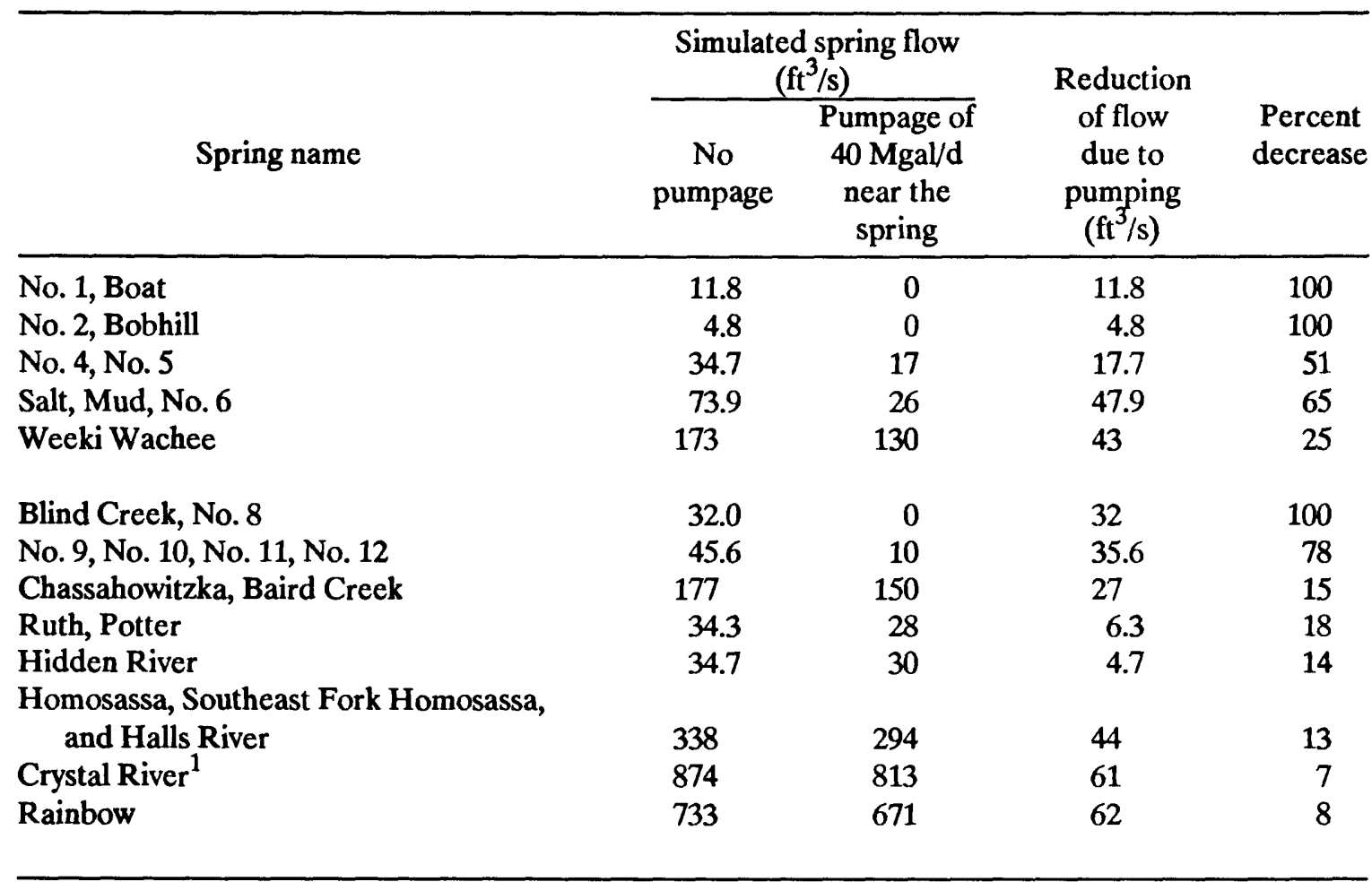

${ }^{1}$ Well located in grid block 9,15 . Simulated flows for grid blocks $10,14-15$ and 9,15 are 816,814 , and $816 \mathrm{ft}^{3} / \mathrm{s}$, respectively. 


\section{Crystal River}

Predictive equations describing the maximum upstream extent of the vertically averaged 5- and 2-ppt salinities were developed in a regression analysis using daily discharge at river mile $\mathbf{3 . 9 2}$ and observed high-tide stage recorded at river mile 3.92. Observed values used for development of regression equations are:
In both equations, tide stage was determined to be more significant than discharge in predicting the salinity locations. A 25-percent increase in tide stage, from 2.22 to 2.78 feet, results in a 0.75 - and 0.60 -mile increase in the distance the vertically averaged 5- and 2-ppt salinities move upstream, respectively, whereas a 25 -percent reduction in streamflow, from 975 to $731 \mathrm{ft}^{3} / \mathrm{s}$,

\begin{tabular}{crcccc}
\hline Observation & Date & $\begin{array}{c}\text { Discharge } \\
\left(\mathrm{ft}^{3} / \mathrm{s}\right)\end{array}$ & $\begin{array}{c}\text { High tide } \\
\text { (feet) }\end{array}$ & $\begin{array}{c}\text { Maximum upstream extent of salinity, } \\
\text { in miles upstream of river mouth }\end{array}$ \\
\hline 1 & $5-24-83$ & 1,090 & 2.52 & $\begin{array}{c}\text { 5 parts } \\
\text { per thousand }\end{array}$ & $\begin{array}{c}\text { 2 parts } \\
\text { per thousand }\end{array}$ \\
\hline 2 & $2-20-85$ & 604 & 1.39 & 3.83 & 4.83 \\
3 & $4-23-85$ & 112 & 2.43 & 2.76 & 3.69 \\
4 & $6-21-85$ & 187 & 2.55 & 5.40 & 6.08 \\
5 & $7-20-85$ & 640 & 2.62 & 4.32 & 5.27 \\
6 & $8-17-85$ & 145 & 2.99 & 5.45 & 6.28 \\
& & & & & \\
7 & $9-14-85$ & 1,280 & 1.09 & 1.85 & 4.00 \\
8 & $11-07-84$ & 1,399 & 7.82 & 1.16 & 2.58 \\
9 & $12-04-84$ & 745 & 1.45 & 2.83 & 4.90 \\
10 & $2-06-85$ & 725 & 1.50 & 2.08 & 5.27 \\
11 & $6-11-85$ & 249 & 1.76 & 4.10 & \\
\hline
\end{tabular}

Salinity data in observations 8 through 11 were collected by Mote Marine Laboratory, Inc. Streamflow was lagged 1 day and was based upon various lag times tested in the regression analysis. Salinity collected on the day of negative discharge does not represent salinity conditions that would exist if spring flow ceased for an extended period. If this occurred, the entire river would eventually contain gulf water.

Daily discharges used in the regression analysis ranged from $-145 \mathrm{ft}^{3} / \mathrm{s}$ to $1,399 \mathrm{ft}^{3} / \mathrm{s}$. These flows were exceeded 97 and 23 percent of the time, respectively, for the period 1964-77. High-tide stages at site 36 ranged from 0.82 to 2.99 feet and were exceeded 99 and 6 percent of the time, respectively, for October 1984 through September 1985.

A summary of the predictive equations and statistics of the regression analysis are as follows: results in a 0.27 - and 0.19 -mile increase in the distance the vertically averaged 5- and 2-ppt salinities move upstream, respectively.

A comparison between high-tide stage and the maximum upstream extent of the vertically averaged 5- and 2-ppt salinities further illustrates the effect of tide stage on salinity location (fig. 34). Despite the scatter of points, the upstream position of the salinities is found farther upstream with increasing tide stage. At the mean higher high-tide stage of 2.0 feet, the vertically averaged 2-ppt salinity is estimated to be about 4.8 miles upstream of the river mouth.

To estimate the percentage of time the vertically averaged 5- and 2-ppt salinities would be at various points in the stream for normal higher high-tide conditions, a high-tide stage of 2.0 feet and historic discharge of known duration (fig. 16) were used with equations 6 and 7 to

\begin{tabular}{|c|c|c|c|c|c|c|}
\hline \multirow[b]{2}{*}{$\begin{array}{c}\text { Equation } \\
\text { No. }\end{array}$} & \multirow[b]{2}{*}{$\begin{array}{l}\text { Salinity } \\
\text { (ppt) }\end{array}$} & \multirow[b]{2}{*}{ Predictive equation } & \multicolumn{4}{|c|}{ Statistics } \\
\hline & & & $\mathbf{R}^{2}$ & RMSE & $\bar{Q}$ & $\overline{\mathrm{HT}}$ \\
\hline 6 & 5.0 & $L=1.34(H T)-0.0011(Q)+1.59$ & 0.92 & 0.45 & 0.0266 & 0.0011 \\
\hline 7 & 2.0 & $L=1.07(H T)-0.0008(Q)+3.12$ & .88 & .44 & .0850 & .0041 \\
\hline
\end{tabular}




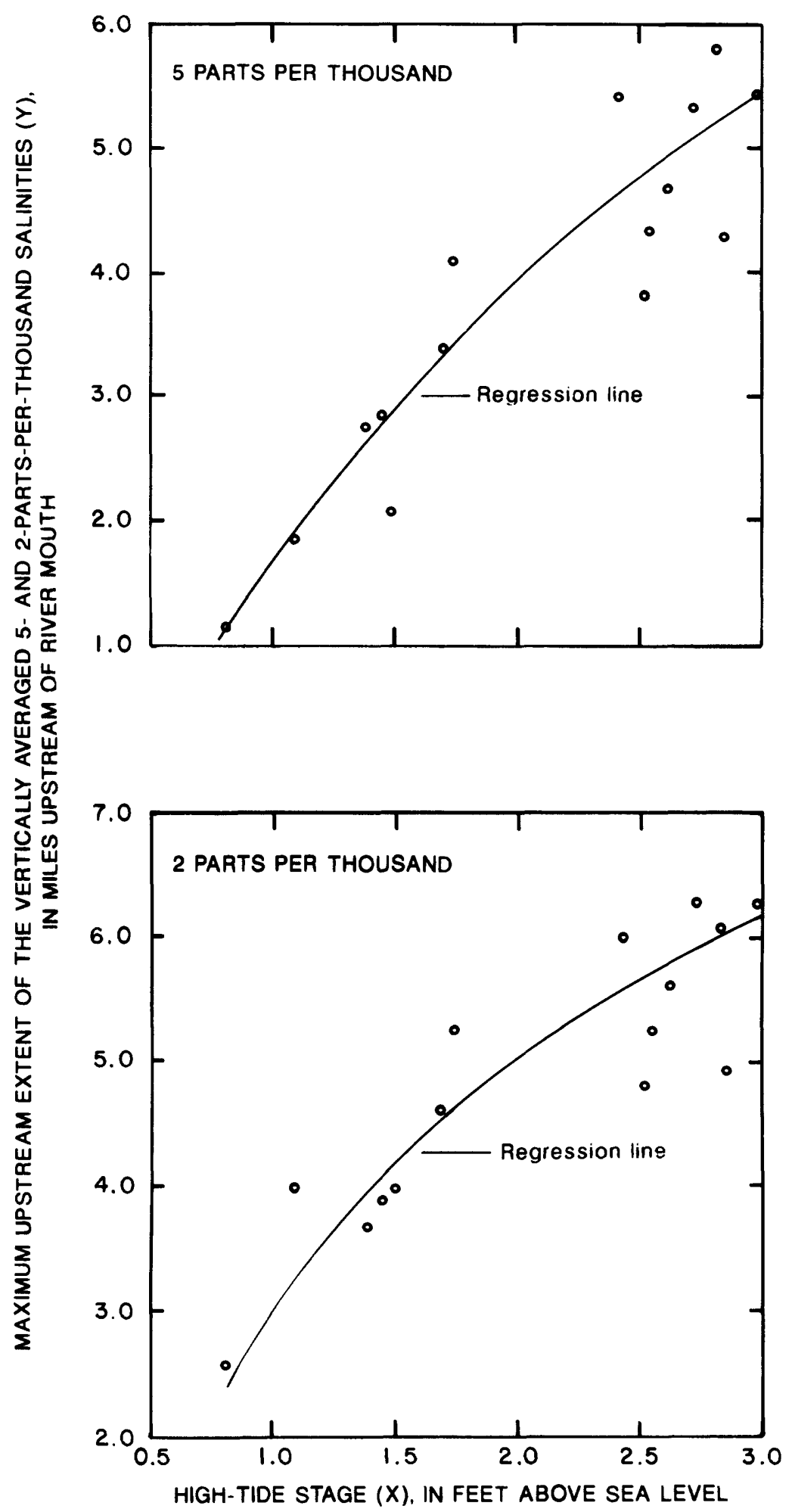

Figure 34. - Relations between high-tide stage of Crystal River at river mile 3.92 and the maximum upstream extent of the vertically averaged 5- and 2-parts-perthousand salinities. 
estimate salinity locations. Daily maximum upstream locations of the vertically averaged 5- and 2-ppt salinities are shown in figure 35. Seventy-five percent of the days, the daily upstream extent of the vertically averaged 2-and 5-ppt salinities will be 4.18 and 2.79 miles or greater upstream of the river mouth, respectively; 25 percent of the days, the daily upstream extent of the vertically averaged 2- and 5-ppt salinities will be 4.78 and 3.65 miles or greater upstream of the river mouth, respectively.

Surface-water withdrawals from the Crystal River for water use may be unlikely because of the river's brackish conditions. The most probable impact on the flow of Crystal River would be from ground water withdrawn from the Upper Floridan aquifer. Table 10 shows that a 40-Mgal/d $\left(61.9 \mathrm{ft}^{3} / \mathrm{s}\right)$ ground-water withdrawal at the Crystal River Springs head would result in a $61-\mathrm{ft}^{3} / \mathrm{s}$ reduction in spring flow and, consequently, in river flow. The reduction of spring flow would be most critical at high-tide and low-flow conditions.

To illustrate the effect of a $61-\mathrm{ft}^{3} / \mathrm{s}$ reduction of discharge on the salinity distribution, a daily mean discharge that corresponds to the 90-day, 20-year recurrence-interval low flow $\left(380 \mathrm{ft}^{3} / \mathrm{s}\right)$ and a mean higher high-tide stage of 2.00 feet were used with equations 6 and 7 to estimate changes in the daily maximum upstream extent of the vertically averaged 5- and 2-ppt salinities. Reducing discharge from 380 to $319 \mathrm{ft}^{3} / \mathrm{s}$ would cause the vertically averaged 5- and 2-ppt salinities to move upstream from river mile 3.85 to 3.92 and from river mile 4.96 to 5.00 , respectively. Although river discharge was reduced by about 16 percent, the net change in upstream extent of saltwater intrusion is within the range of predicted error and not statistically different. Under these low-flow conditions, the main effect on locations of the vertically averaged 5- and 2-ppt salinities is higher high tide. If discharge is decreased, the extent of salinity intrusion will increase.

To estimate possible changes in the frequency of salinity intrusion caused by reduced streamflow, equations 6 and 7 and higher hightide stages of known duration (fig. 3 ) and various constant low-flow discharges were used to estimate salinity locations. The computed daily maximum upstream extent of the vertically averaged 5- and 2-ppt salinities and duration percentage are presented in figure 36 . At a daily discharge of $1,000 \mathrm{ft}^{3} / \mathrm{s}$, the vertically averaged 5- and 2-ppt salinities will be at or upstream of miles 3.5 and 4.7 about 50 percent of the time, respectively. At a daily discharge of $500 \mathrm{ft}^{3} / \mathrm{s}$, the vertically averaged 5- and 2-ppt salinities will be at or upstream of miles 4.0 and 5.1 about 50 percent of the time.

\section{Withlacoochee River}

Salinity data show large differences between surface and bottom salinities near the upstream extent of the saltwater intrusion at high tide. Therefore, predictive equations were developed for locations of the maximum upstream extent of the surface, bottom, and vertically averaged 5- and 0.5-ppt salinities. The discharge recorded on the day prior to each of the salinity runs was used in the regression analysis. Observed values for regression analysis are as follows:

\begin{tabular}{|c|c|c|c|c|c|c|c|c|c|}
\hline \multirow{3}{*}{ Observation } & \multirow{3}{*}{ Date } & \multirow{3}{*}{$\begin{array}{c}\text { Discharge } \\
\left(\mathrm{ft}^{3} / \mathrm{s}\right)\end{array}$} & \multirow{3}{*}{$\begin{array}{l}\text { High tide } \\
\text { (feet) }\end{array}$} & \multicolumn{6}{|c|}{$\begin{array}{l}\text { Maximum upstream extent of salinity, } \\
\text { in miles upstream of river mouth }\end{array}$} \\
\hline & & & & \multicolumn{3}{|c|}{$\begin{array}{l}5 \text { parts } \\
\text { per thousand }\end{array}$} & \multicolumn{3}{|c|}{$\begin{array}{c}0.5 \text { part } \\
\text { per thousand }\end{array}$} \\
\hline & & & & $\begin{array}{l}\text { Sur- } \\
\text { face }\end{array}$ & Bottom & Mean & $\begin{array}{l}\text { Sur- } \\
\text { face }\end{array}$ & Bottom & Mean \\
\hline $\begin{array}{l}1 \\
2 \\
3 \\
4 \\
5 \\
6\end{array}$ & $\begin{array}{r}5-31-84 \\
10-22-84 \\
11-20-84 \\
12-18-84 \\
2-22-85 \\
4-24-85\end{array}$ & $\begin{array}{r}1,590 \\
993 \\
1,160 \\
958 \\
890 \\
542\end{array}$ & $\begin{array}{l}1.90 \\
3.54 \\
1.85 \\
2.05 \\
1.85 \\
3.05\end{array}$ & $\begin{array}{l}0.70 \\
2.48 \\
1.04 \\
1.18 \\
1.28 \\
2.50\end{array}$ & $\begin{array}{l}1.77 \\
3.40 \\
2.42 \\
2.78 \\
2.56 \\
3.42\end{array}$ & $\begin{array}{l}1.24 \\
2.94 \\
1.72 \\
2.32 \\
1.99 \\
2.97\end{array}$ & $\begin{array}{l}1.53 \\
2.85 \\
1.29 \\
1.96 \\
2.18 \\
3.21\end{array}$ & $\begin{array}{l}2.22 \\
3.45 \\
2.51 \\
2.96 \\
2.89 \\
3.73\end{array}$ & $\begin{array}{l}1.88 \\
3.15 \\
1.90 \\
2.56 \\
2.46 \\
3.51\end{array}$ \\
\hline $\begin{array}{r}7 \\
8 \\
9 \\
10 \\
11\end{array}$ & $\begin{array}{l}5-24-85 \\
6-22-85 \\
7-21-85 \\
8-18-85 \\
9-15-85\end{array}$ & $\begin{array}{r}511 \\
606 \\
942 \\
1,610 \\
1,210\end{array}$ & $\begin{array}{l}3.21 \\
3.03 \\
3.46 \\
3.62 \\
2.49\end{array}$ & $\begin{array}{l}2.41 \\
2.61 \\
2.29 \\
2.19 \\
1.80\end{array}$ & $\begin{array}{l}4.13 \\
3.07 \\
3.32 \\
2.65 \\
2.12\end{array}$ & $\begin{array}{l}3.48 \\
2.85 \\
2.81 \\
2.41 \\
1.96\end{array}$ & $\begin{array}{l}2.96 \\
3.38 \\
2.91 \\
2.53 \\
2.36\end{array}$ & $\begin{array}{l}4.36 \\
3.72 \\
3.45 \\
2.74 \\
2.54\end{array}$ & $\begin{array}{l}3.75 \\
3.55 \\
3.18 \\
2.66 \\
2.45\end{array}$ \\
\hline
\end{tabular}



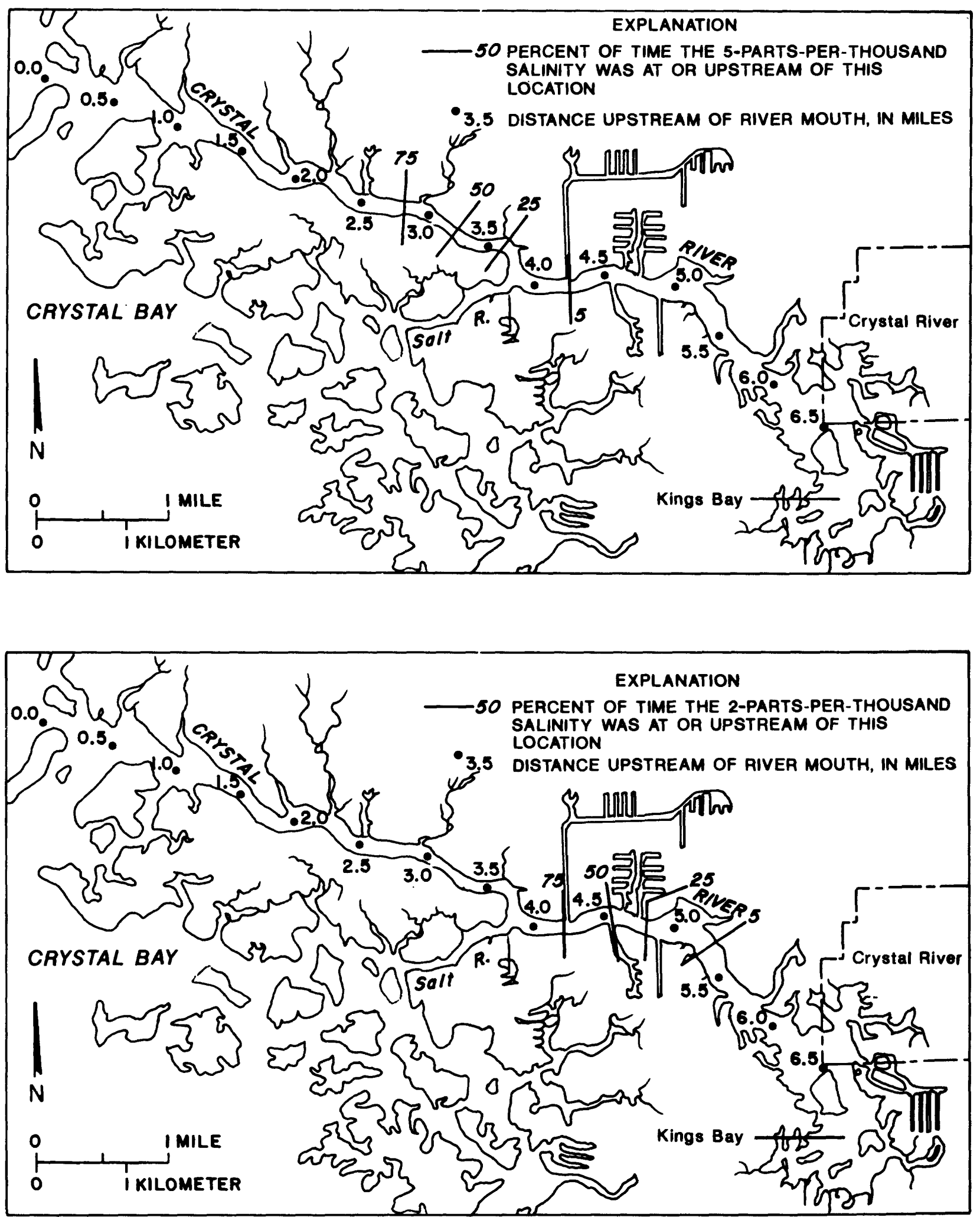

Figure 35.-Duration of the daily maximum upstream extent of the vertically averaged 5- and 2-partsper-thousand salinities in Crystal River for mean higher high-tide stage and variable discharge, October 1984 through September 1985. 


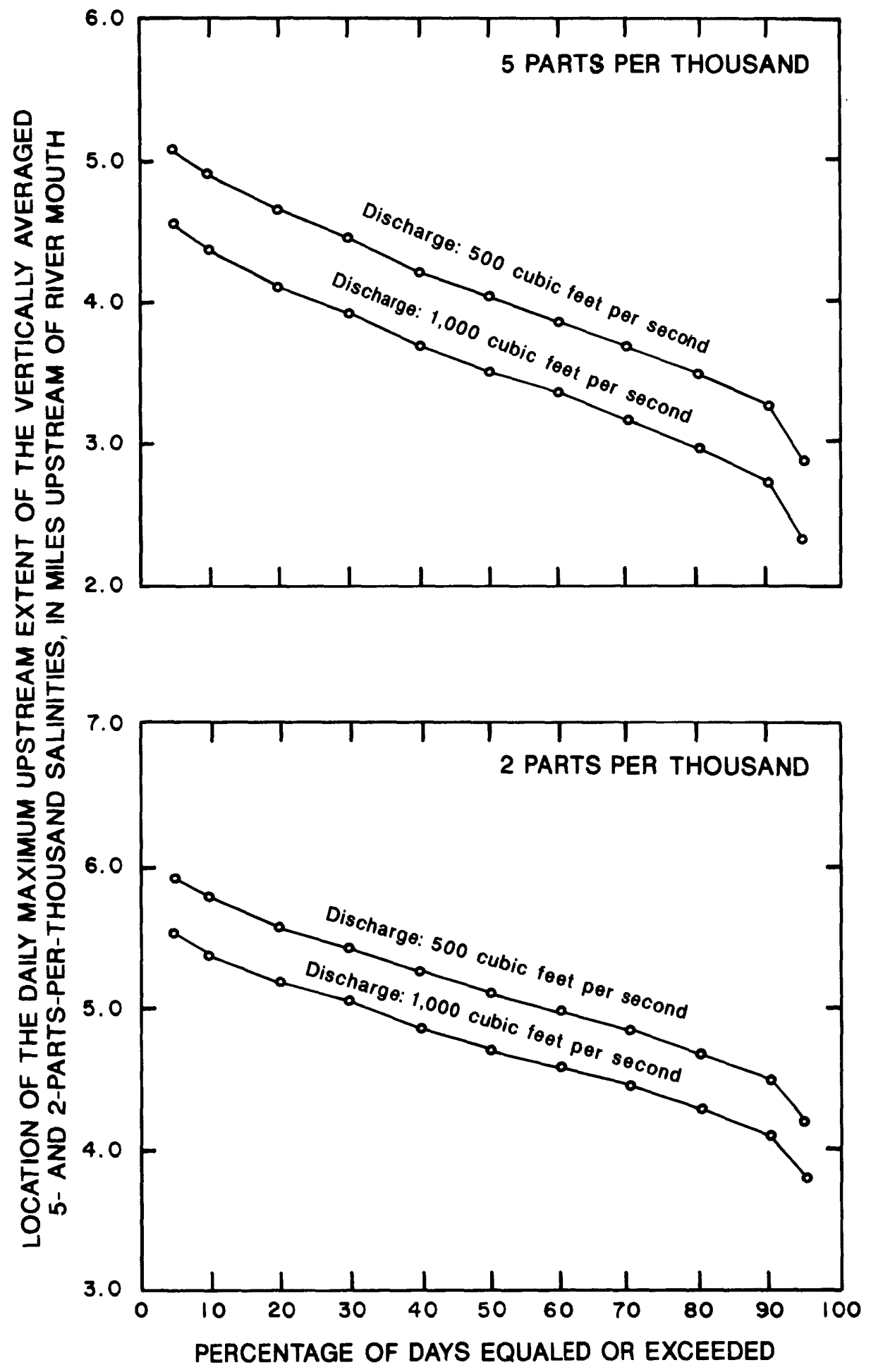

Figure 36. - Duration curves for the daily maximum upstream extent of the vertically averaged 5- and 2-parts-per-thousand salinities in Crystal River for variable higher high tides and discharge, October 1984 through September 1985. 
Discharges used in the regression analysis ranged from 511 to $1,610 \mathrm{ft}^{3} / \mathrm{s}$, which were equaled or exceeded 94 and 2 percent of the time, respectively, for the 14 years of record. High-tide stage ranged from 1.85 to 3.62 feet, which were equaled or exceeded 85 percent and 4 percent of the time during October 1984 through September 1985. A summary of the predictive equations and statistics of the regression analysis are as follows: averaged 5- and 0.5 -ppt salinities cannot be determined using equations 8 through 13 unless a linear relation is assumed.

Predictive equations that describe the location of the daily maximum upstream extent of the vertically averaged 25 - and 18-ppt salinities were developed in a simple linear-regression analysis using observed salinity locations as the dependent variable and maximum recorded salinity for

\begin{tabular}{|c|c|c|c|c|c|c|c|}
\hline \multirow[b]{2}{*}{$\begin{array}{l}\text { Equation } \\
\text { No. }\end{array}$} & \multirow{2}{*}{\multicolumn{2}{|c|}{$\begin{array}{c}\text { Salinity } \\
\text { (ppt) }\end{array}$}} & \multirow[b]{2}{*}{ Predictive equation } & \multicolumn{4}{|c|}{ Statistics } \\
\hline & & & & $\mathbf{R}^{2}$ & RMSE & $\bar{Q}$ & $\overline{\mathrm{HT}}$ \\
\hline $\begin{array}{r}8 \\
9 \\
10\end{array}$ & 5.0 & $\begin{array}{l}\text { Bottom } \\
\text { Surface } \\
\text { Mean }\end{array}$ & $\begin{array}{l}L=0.50(H T)-0.00119(Q)+2.71 \\
L=0.79(H T)-0.00069(Q)+0.39 \\
L=0.59(H T)-0.00106(Q)+1.86\end{array}$ & $\begin{array}{r}0.86 \\
.95 \\
.95\end{array}$ & $\begin{array}{r}0.28 \\
.17 \\
.16\end{array}$ & $\begin{array}{r}0.0012 \\
.0017 \\
.0001\end{array}$ & $\begin{array}{r}0.0043 \\
.0001 \\
.0001\end{array}$ \\
\hline $\begin{array}{l}11 \\
12 \\
13\end{array}$ & 0.5 & $\begin{array}{l}\text { Bottom } \\
\text { Surface } \\
\text { Mean }\end{array}$ & $\begin{array}{l}\mathbf{L}=0.41(\mathrm{HT})-0.00132(\mathrm{Q})+3.33 \\
\mathbf{L}=0.65(\mathrm{HT})-0.00090(\mathrm{Q})+1.59 \\
\mathbf{L}=0.54(\mathrm{HT})-0.00114(\mathrm{Q})+2.47\end{array}$ & $\begin{array}{l}.93 \\
.87 \\
.96\end{array}$ & $\begin{array}{l}.18 \\
.27 \\
.14\end{array}$ & $\begin{array}{l}.0001 \\
.0045 \\
.0001\end{array}$ & $\begin{array}{l}.0001 \\
.0001 \\
.0001\end{array}$ \\
\hline
\end{tabular}

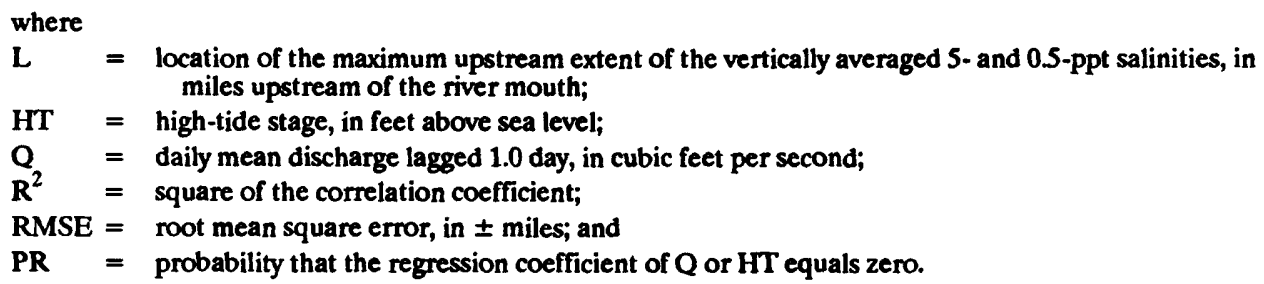

Estimated responses of the upstream extents of the vertically averaged 0.5 - and 5.0-ppt salinities to a 25-percent decrease in streamflow from 1,140 to $855 \mathrm{ft}^{3} / \mathrm{s}$ and to a 25 -percent increase in tide stage from 2.53 to 3.16 feet are shown in table 11. Discharge has a slightly greater effect than tide stage on the bottom position of the vertically averaged 5- and 0.5 -ppt salinities, whereas tide stage has a greater effect than discharge on the surface position of the vertically averaged 5 - and 0.5 -ppt salinities. Locations of the vertically averaged 5- and 0.5 -ppt salinities respond slightly more to changes in tide stage than to changes in discharge. For discharges below $511 \mathrm{ft}^{3} / \mathrm{s}$, estimates of the location of the vertically site 54 at river mile 0.00 as the independent variable. As indicated in figure 37 , there is a direct relation between the maximum upstream extent of the vertically averaged 25 - and 18-ppt salinities and maximum salinity at river mile 0.00 . $R^{2}$ for the equations ranged from 0.67 to 0.82 , and RMSE's ranged from 3.3 to 10.1 percent.

Computed distance-duration curves of the location of the daily maximum upstream extent of the vertically averaged $25-, 18-, 5-$, and $0.5-\mathrm{ppt}$ salinities for October 1984 through September 1985 are shown in figure 38 . Equations 10 and 13 and figure 37 were used in computing the duration curves. The curves show that the 0.5 -ppt salinity generally is found about 1 to 4 miles upstream of the mouth; the 5-ppt salinity

Table 11. - Effect of vanying discharge and high-tide stage on the daily maximum upstream extent of the vertically averaged 5-and 0.5-part-per-thousand salinities in the Withlacoochee River

$\left[\mathrm{ft}^{3} / \mathrm{s}\right.$, cubic feet per second]

\begin{tabular}{ccccccccc}
\hline \multirow{2}{*}{$\begin{array}{c}\text { Streamflow } \\
\left(\mathrm{ft}^{3} / \mathrm{s}\right)\end{array}$} & $\begin{array}{c}\text { High-tide } \\
\text { stage } \\
\end{array}$ & \multicolumn{5}{c}{$\begin{array}{c}\text { Daily maximum upstream extent of salinity, } \\
\text { in miles upstream of river mouth }\end{array}$} \\
\cline { 4 - 9 } & (feet) & Bottom & Surface & Average & & 05 part per thousand \\
\hline 1,140 & 2.53 & 2.62 & 1.60 & 2.14 & 2.86 & 2.21 & 2.54 \\
1,140 & 3.16 & 2.93 & 2.10 & 2.52 & 3.12 & 2.62 & 2.88 \\
855 & 2.53 & 2.96 & 1.80 & 2.45 & 3.24 & 2.46 & 2.86 \\
\hline
\end{tabular}




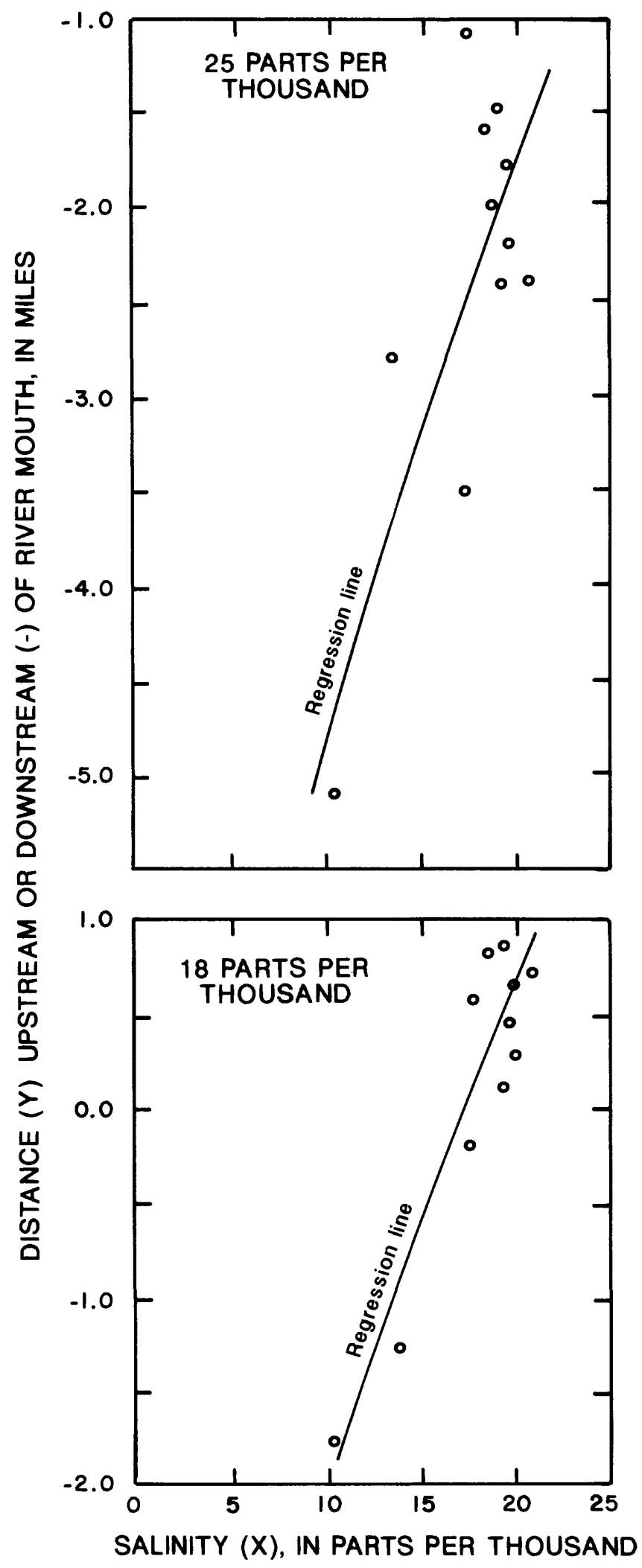

Figure 37. - Relation between salinity at river mile 0.00 and location of the maximum upstream extent of the vertically averaged 18- and 25-parts-per-thousand salinities in the Withlacoochee River Estuary. 


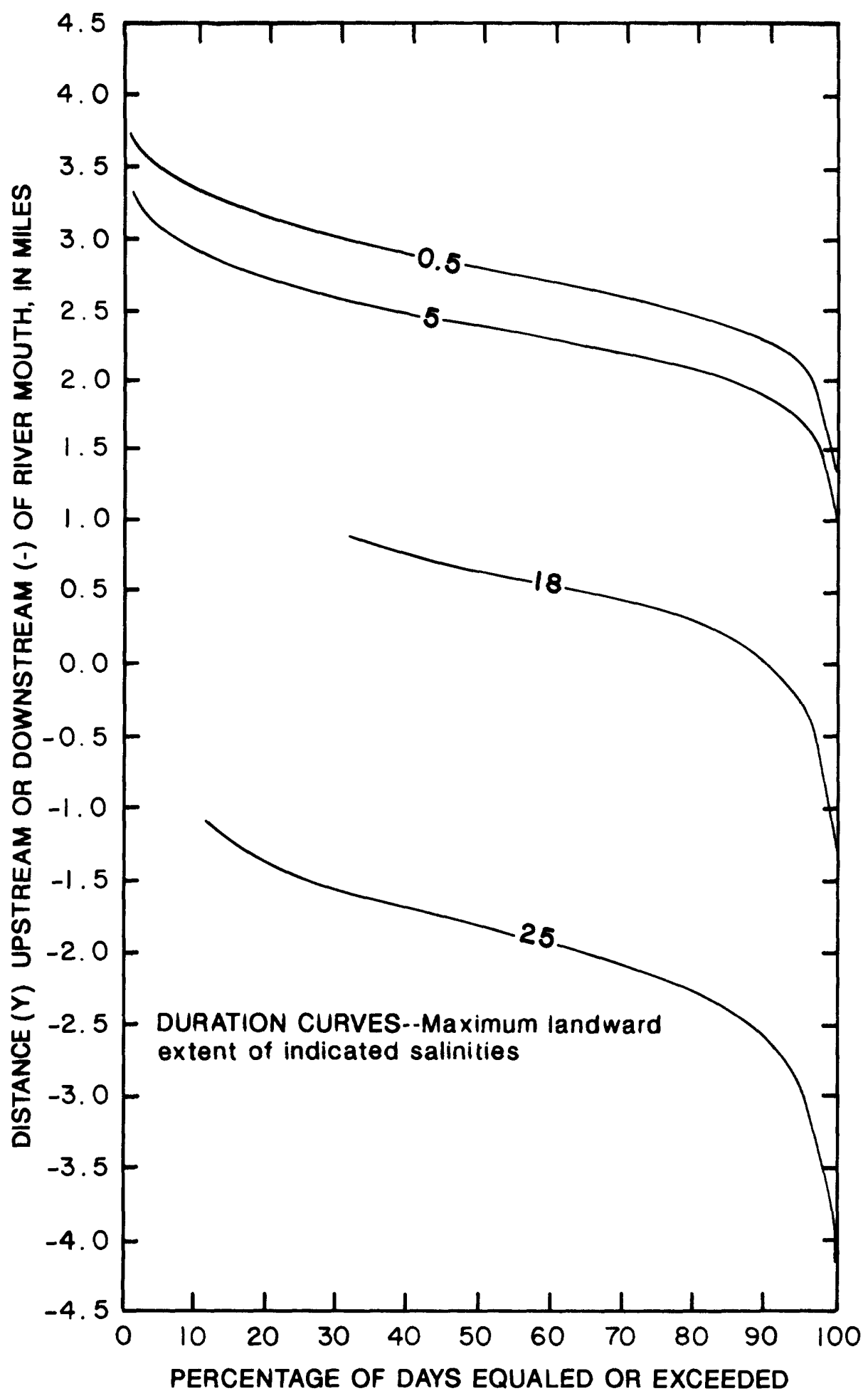

Figure 38. - Duration curves for computed location of the daily maximum upstream extent of the vertically averaged $0.5-, 5-, 18-$, and 25-parts-per-thousand salinities in the Withlacoochee River Estuary, October 1984 through September 1985. 
generally is found about 0.5 to 3.5 miles upstream of the mouth; the 18-ppt salinity can be expected to be found offshore of the river mouth about 10 percent of the days; and the 25-ppt salinity can be expected to be found offshore of the river mouth more than 90 percent of the days. Locations and durations of the upstream extent of the vertically averaged 5- and 0.5-ppt salinities in the Withlacoochee River for the period of study are shown in figure 39.

Low-flow characteristics of streams often determine their suitability as a source of water (Hammett, 1985). To illustrate the effects of withdrawal on the location of the daily maximum upstream extent of the vertically averaged 5- or 0.5 -ppt salinities, low-flow discharges and a mean higher high-tide stage of 2.52 feet were used with equations 10 and 13 to estimate changes in salinity locations. A 50-percent reduction in the 90-day, 2-year low flow (from 830 to $415 \mathrm{ft}^{3} / \mathrm{s}$ ) would cause an upstream movement of the vertically averaged 5-ppt salinity of about 0.4 mile (from mile 2.5 to 2.9) and an upstream movement of the vertically averaged 0.5 -ppt salinity of about 0.5 mile (from mile 2.9 to 3.4). For the 7-day, 2-year low flow $\left(670 \mathrm{ft}^{3} / \mathrm{s}\right)$, a 50 -percent reduction of discharge (from 670 to $335 \mathrm{ft}^{3} / \mathrm{s}$ ) would cause an upstream movement of the vertically averaged 5 -ppt salinity of about 0.4 mile (from mile 2.6 to 3.0) and an upstream movement of the vertically averaged 0.5 -ppt salinity of about $\mathbf{0 . 3}$ mile (from mile 3.1 to 3.4 ). The estimated change in upstream extent of saltwater intrusion is small considering the large reductions in discharge.

Changes in flow also affect the frequency of salinity intrusion. To estimate possible changes in the frequency of salinity intrusion caused by reduction in river discharge, higher high tides of known duration (fig. 3) and various constant low-flow discharges were used with equations 10 and 13 . The computed daily maximum upstream extent of the vertically averaged 5- and 0.5 -ppt salinities and duration percentages are presented in figure 40 . At a discharge of $500 \mathrm{ft}^{3} / \mathrm{s}$, the vertically averaged 5 - and 0.5 -ppt salinities will be at or upstream of river miles 2.8 and 3.3 about 50 percent of the year, respectively. At a discharge of $1,000 \mathrm{ft}^{3} / \mathrm{s}$, the vertically averaged 5- and 0.5-ppt salinities will be at or upstream of river miles 2.3 and 2.7 , respectively, about 50 percent of the year.

Figure 40 also can be used to estimate the required discharge needed to maintain upstream salinity at certain points in the stream for fixed durations. For instance, to restrict the vertically averaged 0.5 -ppt salinity from reaching river mile 3.0 on high tides for no more than $\mathbf{3 0}$ percent of the year would require a continuous discharge of about $910 \mathrm{ft}^{3} / \mathrm{s}$. To restrict the vertically averaged 5-ppt salinity downstream of river mile $\mathbf{3 . 0}$ for $\mathbf{3 0}$ percent of the year would require a continuous discharge of about $540 \mathrm{ft}^{3} / \mathrm{s}$.

The effect of reducing discharge on salinity intrusion for certain sections of the river can also be estimated. Applying figure 40, a 50-percent reduction of the 90-day, 20-year low flow, from 830 to $415 \mathrm{ft}^{3} / \mathrm{s}$, would increase the frequency of daily salinity intrusion (0.5-ppt salinity) at river mile 3.0 from 33 to 85 percent. This would allow the vertically averaged 0.5 -ppt salinity to reach this section of the river with high tides on an additional 190 days per year. At river mile 2.5, a 50-percent reduction of the 90-day, 20-year low flow would increase daily salinity intrusion from 83 to 100 percent of the days per year.

\section{SUMMARY}

The Weeki Wachee, Crystal, and Withlacoochee Rivers are coastal streams in Citrus and Hernando Counties that discharge about 2,300 $\mathrm{ft}^{3} / \mathrm{s}$ of water to the Gulf of Mexico. With the exception of the Withlacoochee River, each of the rivers originates from a group of springs that provide almost the entire flow of the river. Waters of the Weeki Wachee and Withlacoochee Rivers are characterized by a dilute, relatively constant mineral content, whereas waters of the Crystal River are characterized by a variable and relatively higher mineral content.

There is little surface drainage in the study area. With the exception of the Withlacoochee River, there are no streams that extend more than a few miles inland. Most water in the rivers is derived from water in the Upper Floridan aquifer. Discharge from the aquifer to springs and seeps along the coast is primarily through solution cavities in the limestone and dolomite strata of the Upper Floridan aquifer, which is at or near land surface in the area. Saltwater is present in the upper part of the aquifer along the coast, and springs may discharge either freshwater or saline water.

Salinity concentrations of the rivers decrease upstream, and differences between surface and bottom salinities vary from river to river. The 

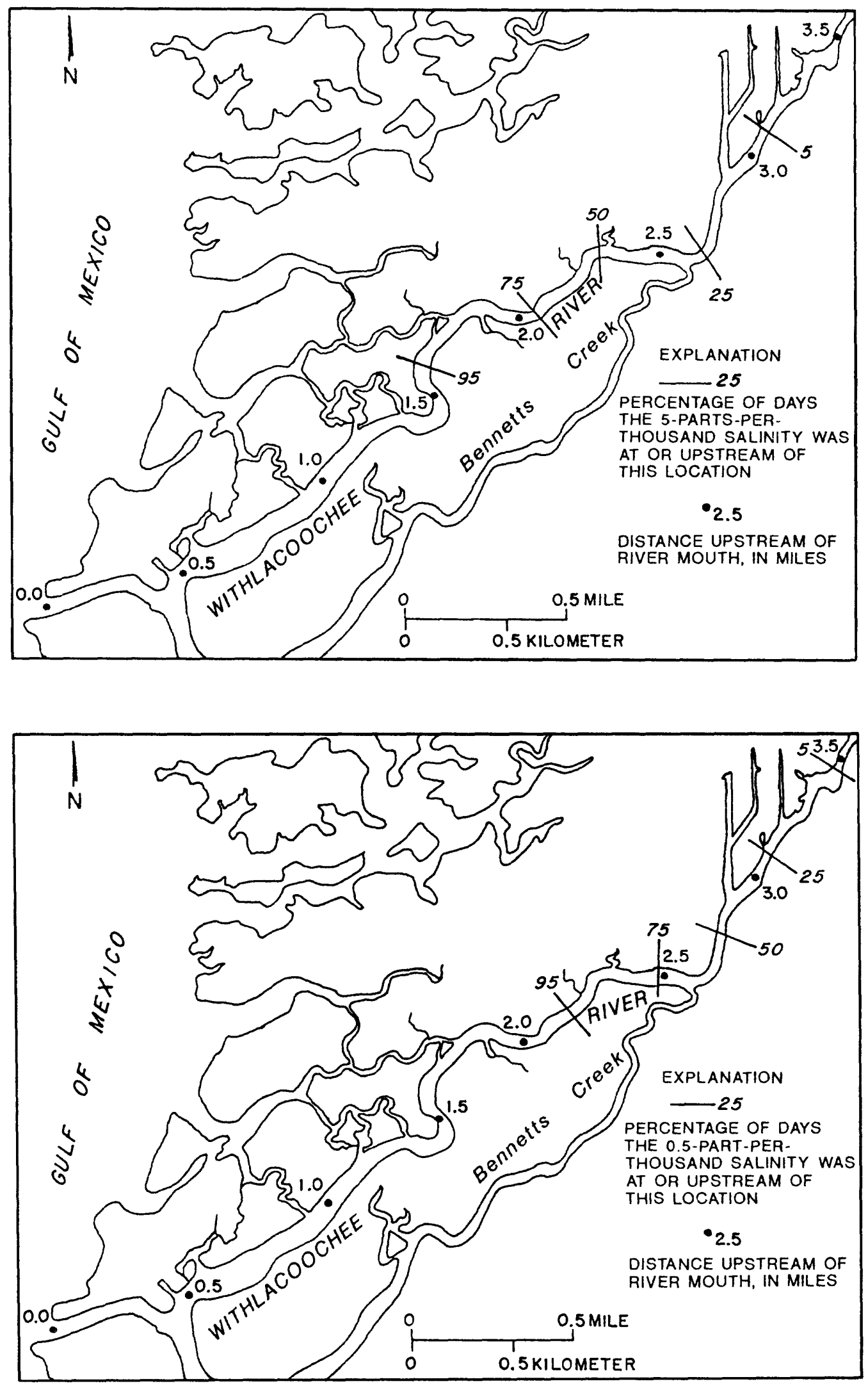

Figure 39. - Duration of the daily maximum upstream extent of the vertically averaged 5- and 0.5-part-per-thousand salinities in the Withlacoochee River, October 1984 through September 1985. 


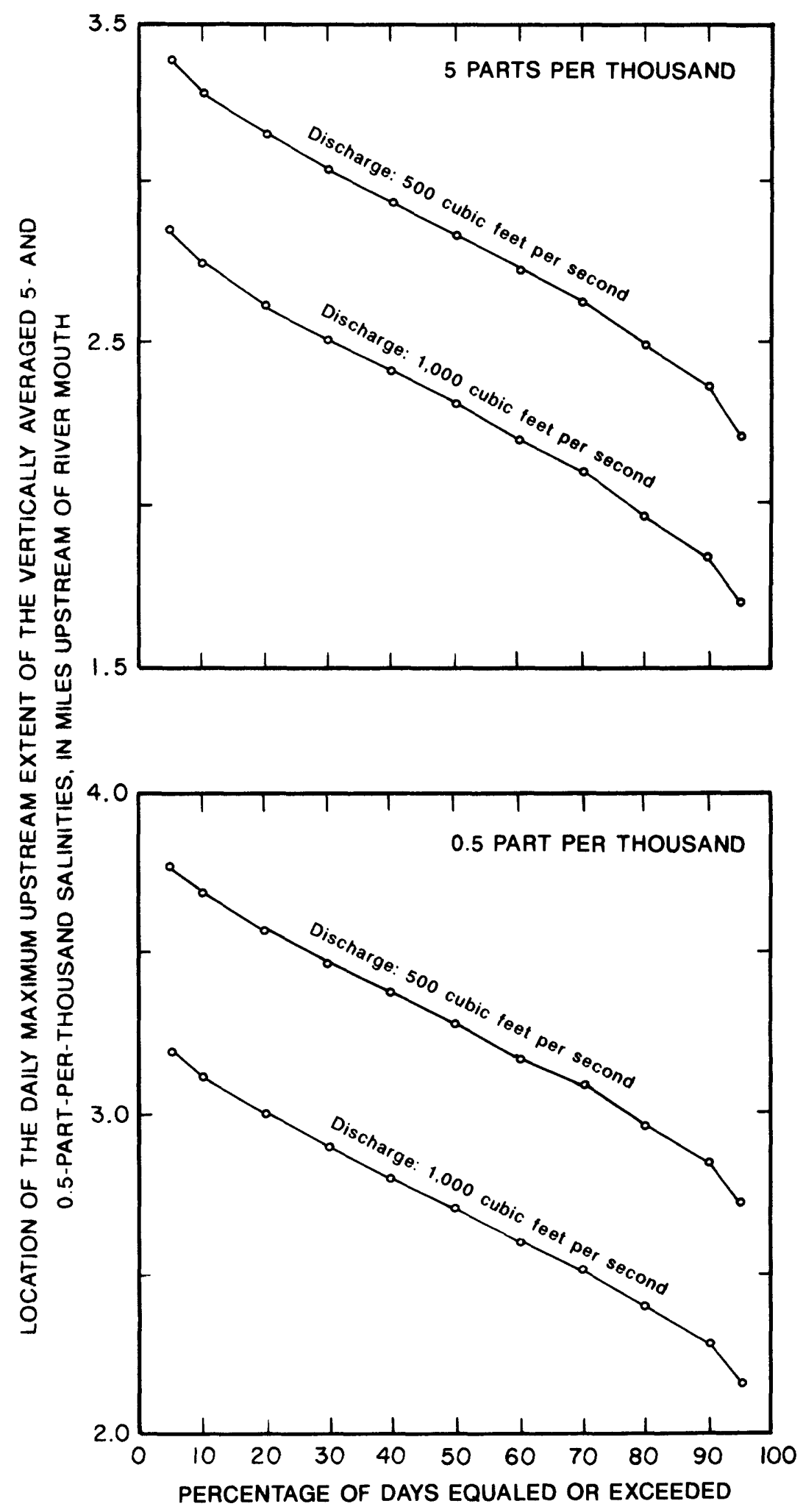

Figure 40.-Duration curves of the daily maximum upstream extent of the vertically averaged 5- and 0.5 -part-perthousand salinities in the Withlacoochee River for higher high tides and discharge, October 1984 through September 1985. 
Weeki Wachee River Estuary is the best mixed of the three. The Crystal River Estuary is the next best mixed, and the Withlacoochee River Estuary is the least vertically mixed of the three.

The extent of saltwater intrusion in these estuaries at high tide is a function of tide stage and river discharge. Maximum upstream intrusion of saltwater in the rivers occurs at low streamflow and higher high-tide stages, and minimum saltwater intrusion occurs at high streamflow and lower high-tide stages. In the Weeki Wachee and Withlacoochee Rivers, lowconcentration salinities appear to be less sensitive to changes in discharge and high-tide stage and migrate over a shorter distance than high-concentration salinities. In Crystal River, locations of high-concentration salinities appear to be less sensitive to changes in flow and hightide stage and migrate over a shorter distance than low-concentration salinities.

Salinity duration analysis indicates the percentage of time salinities exceed different levels at fixed points in the rivers. In the Weeki Wachee River, salinity above $0.5 \mathrm{ppt}$ was present about 17 percent of the time at river mile 1.37 and 100 percent of the time at river mile 0.05 . In Crystal River, salinity above 2 ppt was present about 39 percent of the time at river mile 3.92 and about 6 percent of the time at river mile 5.92. In the Withlacoochee River, salinities above $0.5 \mathrm{ppt}$ were present about 27 percent of the time at river mile 2.96 , about 72 percent of the time at river mile 1.70 , and about 99 percent of the time at river mile 0.00 .

Predictive equations that relate river discharge, high-tide stage, and the maximum upstream extent of salinity intrusion in each river were developed using regression techniques. For the Weeki Wachee River, two linear equations with different discharge ranges were developed for the locations of the vertically averaged 5- and 0.5 -ppt salinities. Streamflow was the most significant variable in each equation. Values of $\mathbf{R}^{2}$ ranged from 0.54 to 0.88 and the root mean square errors ranged from \pm 0.10 to \pm 0.36 mile. For Crystal River, one linear equation was developed for each salinity location. Tide stage was the most significant variable for each equation. Values of $R^{2}$ ranged from 0.88 to 0.92 and the root mean square errors ranged from \pm 0.44 to \pm 0.45 mile. For the Withlacoochee River, linear equations were developed for the location of the surface, bottom, and vertically averaged 5 - and 0.5 -ppt salinities. Streamflow was the most significant variable in locating the bottom salinity position, and tide stage was the most significant variable in locating the surface salinity position. The location of both salinities responded slightly more to tide stage than to streamflow. Values of $R^{2}$ ranged from 0.86 to 0.96 and the root mean square errors ranged from \pm 0.14 to \pm 0.28 mile.

$A$ duration analysis indicates the percentage of days the computed daily maximum upstream extent of different salinities were located at points in the Weeki Wachee and Withlacoochee River Estuaries during October 1984 through September 1985. In the Weeki Wachee River Estuary, the vertically averaged 0.5 -ppt salinity can be expected to be found between 1 and 2 miles upstream of the river mouth, whereas the vertically averaged 25 -ppt salinity can be expected to be found 0 to 6 miles offshore. In the Withlacoochee River Estuary, the vertically averaged 0.5 -ppt salinity is generally found 1 to 4 miles upstream of the river mouth, whereas the vertically averaged 25 -ppt salinity can be expected to be found offshore more than 90 percent of the days.

A duration analysis for Crystal River Estuary for normal higher high-tide stage (2.0 feet) indicates the daily maximum upstream extent of the vertically averaged 5- and 2-ppt salinities would be 2.79 and 4.18 miles, respectively, upstream of the river mouth 75 percent of the days and 3.65 and 4.78 miles, respectively, upstream of the river mouth 25 percent of the days.

The effects of pumping $40 \mathrm{Mgal} / \mathrm{d}\left(61.9 \mathrm{ft}^{3} / \mathrm{s}\right)$ from a well field near the springs on upstream salinity intrusion in the Weeki Wachee and Crystal Rivers were estimated. In the Weeki Wachee River, the resulting $43-\mathrm{ft}^{3} / \mathrm{s}$ reduction in spring flow, from 199 to $156 \mathrm{ft}^{3} / \mathrm{s}$, would cause an upstream movement of both the vertically averaged 5- and 0.5-ppt salinities of about 0.2 mile. In the Crystal River, a $61-\mathrm{ft}^{3} / \mathrm{s}$ reduction in spring flow, from 380 to $319 \mathrm{ft}^{3} / \mathrm{s}$, would cause an upstream movement of both the vertically averaged 5- and 2-ppt salinities of less than 0.1 mile.

Surface withdrawal of $415 \mathrm{ft}^{3} / \mathrm{s}$ ( 50 percent of the 90-day, 2-year low flow) from the Withlacoochee River is predicted to cause an upstream movement of both the vertically averaged 5- and 0.5 -ppt salinities of about 0.4 mile. It also would increase the frequency of salinity above $0.5 \mathrm{ppt}$ at river mile 3.0 from 33 to 85 percent. 
Reduction of river discharge will affect the upstream extent of saltwater intrusion in the rivers; however, under certain reduced low-flow discharges, the estimated change in upstream location of the saltwater intrusion is on the order of several tenths of a mile and often is within the range of predicted error. Under certain discharges, the main effect on upstream locations of saltwater intrusion is higher high tide.

\section{SELECTED REFERENCES}

Barr, G.L., 1985, Potentiometric surface of the Upper Floridan aquifer, west-central Florida, May 1985: U.S. Geological Survey Open-File Report 85-482, 1 sheet.

Beverage, J.P., and Swecker, M.N., 1969, Estuarine studies in upper Grays Harbor, Washington: U.S. Geological Survey WaterSupply Paper 1873-B, 87 p.

Brooks, H.K., 1973, Geological oceanography, in A summary of the knowledge of the eastern Gulf of Mexico: State University System of Florida Institute of Oceanography, March 1973.

Bush, P.W., 1973, Salt-water movement in the lower Withlacoochee River-Cross Florida Barge Canal complex: U.S. Geological Survey Water-Resources Investigations 5-72, $82 \mathrm{p}$.

Cherry, R.N., Stewart, J.W., and Mann, J.A., 1970, General hydrology of the Middle Gulf area, Florida: Florida Bureau of Geology Report of Investigations 56, $96 \mathrm{p}$.

Cohen, Bernard, and McCarthy, L.T., Jr., 1962, Salinity of the Delaware Estuary: U.S. Geological Survey Water-Supply Paper 1586-B, $47 \mathrm{p}$.

Cummings, T.R., 1968, Salt-water encroachment in the South Edisto River Estuary, South Carolina: U.S. Geological Survey WaterSupply Paper 1586-I, 19 p.

Faulkner, G.L., 1973, Ground-water conditions in the lower Withlacoochee River-Cross Florida Barge Canal complex area: U.S. Geological Survey Water-Resources Investigations 4-72, $31 \mathrm{p}$.

Fernandez, Mario, Jr., 1985, Salinity characteristics and distribution and effects of alternate plans for freshwater withdrawal, Little Manatee River Estuary and adjacent areas of Tampa Bay, Florida: U.S. Geological Survey Water-Resources Investigations Report 84-4301, 45 p.

Forch, C., Knudsen, Martin, and Sorenson, S.P.L., 1902, Berichte Uber die Konstantenbestimmungen Zur Aufstellung der hydrographischen Tabollen, D. Kgl. Danske Vidensk Selsk. Skrifter, 6. Raekke, Naturvidensk. OG Mathem, Afd. XII. 1, $151 \mathrm{p}$.

Fretwell, J.D., 1983, Ground-water resources of coastal Citrus, Hernando, and southwestern Levy Counties, Florida: U.S. Geological Survey Water-Resources Investigations Report 83-4079, 87 p.

German, E.R., 1978, The hydrology of Lake Rousseau, west-central Florida: U.S. Geological Survey Water-Resources Investigations 77-126, 1 sheet.

Giovannelli, R.F., 1981, Relation between freshwater flow and salinity distribution in the Alafia River, Bullfrog Creek, and Hillsborough Bay, Florida: U.S. Geological Survey Water-Resources Investigations 80-102, 68 p.

Hammett, K.M., 1985, Low-flow frequency analysis for streams in west-central Florida: U.S. Geological Survey Water-Resources Investigations Report 84-4299, 116 p.

Jones, J.I., 1973, Physical oceanography of the northeast Gulf of Mexico and Florida continental shelf area, in A summary of knowledge of the eastern Gulf of Mexico: State University System of Florida Institute of Oceanography, March 1973.

Jordan, C.L., Climate, in A summary of knowledge of the eastern Gulf of Mexico: State University System of Florida Institute of Oceanography, March 1973.

Keighton, W.B., 1966, Fresh-water discharge salinity relations in the tidal Delaware River: U.S. Geological Survey Water-Supply Paper 1586-G, 16 p.

Mann, J.A., and Cherry, R.N., 1969, Large springs of Florida's "Sun Coast," Citrus and Hernando Counties, Florida: Florida Bureau of Geology Leaflet no. 9, 23 p.

Mills, L.R., and Ryder, P.D., 1977, Saltwater intrusion in the Floridan aquifer, coastal Citrus and Hernando Counties, Florida, 1975: U.S. Geological Survey WaterResources Investigations 77-100, 1 sheet. 
Rosenau, J.C., Faulkner, G.L., Hendry, C.W., Jr., and Hull, R.W., 1977, Springs of Florida (revised): Florida Bureau of Geology Bulletin 31, $461 \mathrm{p}$.

Russell, G.M., and McPherson, B.F., 1984, Freshwater runoff and salinity distribution in the Loxahatchee River Estuary, southeastern Florida, 1980-82: U.S. Geological Survey Water-Resources Investigations Report 83-4244, $36 \mathrm{p}$.

Santos, J.F., and Stoner, J.D., 1972, Physical, chemical, and biological aspects of the Duwamish River Estuary, King County, Washington, 1963-67: U.S. Geological Survey Water-Supply Paper 1873-C, 74 p.

Sinclair, W.C., 1978, Preliminary evaluation of the water-supply potential of the spring-river system in the Weeki Wachee area and the lower Withlacoochee River, west-central Florida: U.S. Geological Survey WaterResources Investigations 78-74, $40 \mathrm{p}$.

Southwest Florida Water Management District, 1968, Report of investigation of the Weeki Wachee River: $14 \mathrm{p}$.
U.S. Department of Commerce, 1985, Tide tables, high and low water predictions, east coast of North and South America, including Greenland: National Oceanic and Atmospheric Administration, National Ocean Survey, 285 p.

Vernon, R.O., 1951, Geology of Citrus and Levy Counties, Florida: Florida Geological Survey Bulletin 33, 256 p., 2 pl.

Wetterhall, W.S., 1964, Geohydrologic reconnaissance of Pasco and southern Hernando Counties, Florida: Florida Geological Survey Report of Investigations 34, 28 p.

White, W.A., 1970, The geomorphology of the Florida Peninsula: Florida Geological Survey Bulletin 51, 164 p.

Yobbi, D.K., 1989, Simulation of steady-state ground water and spring flow in the Upper Floridan aquifer of coastal Citrus and Hernando Counties, Florida: U.S. Geological Survey Water-Resources Investigations Report 88-4036, 33 p. 